\title{
MINISTRY OF EDUCATION AND SCIENCE OF UKRAINE
}

V.N. KARAZIN KHARKIV NATIONAL UNIVERSITY

\section{COGNITION, COMMUNICATION, DISCOURSE}

\section{Series "Philology"}

\section{\# 16}

International on-line scholarly journal

http://sites.google.com/site/cognitiondiscourse/

Published since 2010

Included in the list of specialized scientific publications in Ukraine

(The order of the Ministry of Education and Science of Ukraine from 07.10.2016 № 1222) 
The articles in this magazine cover essential problems of philology and translation studies. On the material of English, Ukrainian and other languages, linguists - $\mathrm{PhD}$, professors from different cities of Ukraine and Armenia consider important issues of cognitive science and ethnopsycholinguistics; discourse analysis; structure and semantics of narrative in the fairy tale; linguocultural studies.

For linguists, teachers, graduate students and undergraduates.

\section{Editor-in-Chief:}

Iryna Shevchenko, Doctor, Professor (V.N. Karazin Kharkiv National University, Ukraine), iryna.shevchenko@karazin.ua; https://orcid.org/0000-0003-2552-5623 https://scholar.google.com.ua/citations?user=uHkA_kgAAAAJ\&hl=ru

\section{Vice Editor-in-Chief:}

Y.V. Bondarenko, Doctor, Professor (V.N. Karazin Kharkiv National University, Ukraine), ievgeniia.bondarenko.2014@gmail.com; https://orcid.org/0000-0003-0654-1791 https://scholar.google.com.ua/citations?user=IPdzaq4AAAAJ\&hl

\section{Consultant Editors:}

Ronald W. Langacker, Doctor, Professor (University of California, San Diego, USA), http://idiom.ucsd.edu/ rwl/ Suzanne Kemmer, Doctor, Professor (Rice University, Huston, USA), kemmer@ rice.edu

\section{Technical editor:}

M.V. Kotov, Doctor, Associate Professor (V.N. Karazin Kharkiv National University, Ukraine), mykhailo.kotov@karazin.ua; https://orcid.org/0000-0001-8327-5197

\section{Executive secretary}

A.B. Kalyuzhna, Doctor, Associate Professor (V.N. Karazin Kharkiv National University, Ukraine), alevtyna_16@ukr.net; https://orcid.org/0000-0003-4305-5311 https://scholar.google.com.ua/citations?user=p6Fx2PIAAAAJ\&hl=uk

\section{Editorial Board:}

Donka Alexandrova, Doctor, Professor (University St.Kliment Ohridski, Sofia, Bulgaria), donka_bar@hotmail.com

A.D. Belova, Doctor, Professor (Kyiv National Taras Shevchenko University, Ukraine), profbelova@ gmail.com

L.R. Bezugla, Doctor, Professor (V.N. Karazin Kharkiv National University, Ukraine), bezugla@ daad-alumni.de; https://scholar.google.com.ua/citations?user=cnY6SDAAAAAJ\&hl=ru

Natalia Chaban, Doctor, Associate Professor (University of Canterbury, Christchuch, New Zeland), natalia.chaban@canterbury.ac.nz

V.E. Chernyavskaya, Doctor, Professor (Peter the Great St. Petersburg Polytechnic University, Russia), tcherniavskaia@rambler.ru; https://orcid.org/0000-0002-6039-6305

Margaret H. Freeman, Doctor, Professor Emeritus, Co-director (Merrifield Institute for Cognition and the Arts, Heath, USA), freemamh@lavc.edu

Seda Q. Gasparyan, Doctor, Professor (Yerevan State University, Armenia), sedagasparyan@yandex.com

Alina Israeli, Doctor, Associate Professor, Department of World Languages and Cultures, (American University, Washington, D.C., USA), aisrael@american.edu

V.I. Karasik, Doctor, Professor (Volgograd State Pedagogical University, Russia), vladimir_karasik@mail.ru; researcher ID: C-3975-2016

Y.A. Karpilovska, Doctor, Professor (Ukrainian Language Institute, National Academy of Sciences, Kyiv, Ukraine), karpilovska@gmail.com https://scholar.google.com/citations?user=3e9ovmAAAAAJ\&hl=ru

Gerhard Koller, Doctor, Professor, Doctor Honoris Causa (Friedrich Alexander University, Erlangen-Nuremberg, Germany), gerhard.koller@fau.de

G.N. Manaenko, Doctor, Professor (Stavropol State Pedagogic Institute, Russia), manaenko@list.ru; https://scholar.google.com.ua/citations?user=Az1SInUAAAAJ\&hl=ru

A.P. Martyniuk, Doctor, Professor (V.N. Karazin Kharkiv National University, Ukraine), allamartynyuk@ukr.net; http://orcid.org/0000-0003-2804-3152;

https://scholar.google.com.ua/citations?hl=ru\&user=sWGUJgcAAAAJ\&view_op=list_works\&authuser=1

Francisco D. Matito, Doctor, Professor Titular (University of La Rioja, Spain), fd.matito@unirioja.es

Maureen C. Minielli, Associate Professor (City University of New York, USA), mo.minielli@me.com; https://orcid.org/0000-0003-0831-8681 
S.A. Moiseyeva, Doctor, Professor (Belgorod State Research University, Russia), moisseeva@bsu.edu.ru; https://orcid.org/0000-0003-0909-3154

O.I. Morozova, Doctor, Professor (V.N. Karazin Kharkiv National University, Ukraine), elena.i.morozova@gmail.com; https://scholar.google.com.ua/citations?user=uHN4AZYAAAAJ\&hl=ru

Ben O'Loughlin, Professor (Royal Holloway, University of London, UK), ben.oloughlin@ rhol.ac.uk

V.G. Pasynok, Doctor, Professor (V.N. Karazin Kharkiv National University, Ukraine), fl@karazin.ua; https://scholar.google.com.ua/citations?user=yEociXAAAAAJ\&hl

A.M. Prykhodko, Doctor, Professor (Zaporizhzhia National Technical University, Ukraine), aprykhod@mail.ru; https://orcid.org/0000-0001-5051-8711;

https://scholar.google.com/citations?hl=ru\&authuser=1\&user=hZTG75IAAAAJ

https://scholar.google.com.ua/citations?user=9WnGLUcAAAAJ\&hl=ru

O.V. Rebrij, Doctor, Professor (V.N. Karazin Kharkiv National University, Ukraine), rebriy@vega.com.ua; http://orcid.org/0000-0002-4912-7489; https://scholar.google.com/citations?user=ak5-nc8AAAAJ\&hl=en

V.O. Samokhina, Doctor, Professor (V.N. Karazin Kharkiv National University, Ukraine), samokhina.victoria@gmail.com; https://orcid.org/0000-0002-6216-2502; https://scholar.google.com.ua/citations?user=0us2VTAAAAAJ\&hl=ru

L.V. Soloschuk, Doctor, Professor (V.N. Karazin Kharkiv National University, Ukraine), 1solo@ukr.net; https://scholar.google.com.ua/citations?user=0sKbFhMAAAAJ\&hl=uk

Daniel Vanderveken, Doctor, Full Professor (University of Quebec at Trois-Rivières, Canada), daniel.vanderveken@gmail.com

O.P. Vorobyova, Doctor, Professor (Kyiv National Linguistic University, Ukraine), o.p.vorobyova@gmail.com; http://orcid.org/0000-0001-9039-9737; https://scholar.google.com.ua/citations?user=CEcKrM8AAAAJ\&hl=ru\&oi=ao

S.A. Zhabotinska, Doctor, Professor (Bogdan Khmelnitsky Cherkassy National University, Ukraine), saz9@ukr.ne; https://scholar.google.ru/citations?user=rEu1MRoAAAAJ\&hl=ru https://independent.academia.edu/SvitlanaZhabotynska

Editorial Address:

Ukraine, 61022, Kharkov, Svobody square, 4 (V.N. Karazin Kharkiv National University, Ukraine)

Faculty of Foreign Languages

Tel.: (057) 707-51-44

Internet-page: http://sites.google.com/site/cognitiondiscourse/

All articles are peer reviewed

Published 2 issues a year

Recommended by the Academic Council of V.N. Karazin Kharkiv National University

(Minutes № 6 of May $28^{\text {th }}, 2010$ )

This open access peer reviewed journal is indexed in ERIH PLUS Index database as

«Kognitsia, kommunikatsia, diskurs».

(https://dbh.nsd.uib.no/publiseringskanaler/erihplus/periodical/info?id=491014) 


\author{
МІНІСТЕРСТВО ОСВІТИ І НАУКИ УКРАЇНИ \\ ХАРКІВСЬКИЙ НАЦІОНАЛЬНИЙ УНІВЕРСИТЕТ \\ імені В.Н. КАРАЗІНА
}

\title{
КОГНІЦЯ, КОМУНІКАЦІЯ, ДИСКУРС
}

\section{Напрямок “Філологія"}

\author{
№ 16 \\ Міжнародний електронний збірник наукових праць \\ Започаткований у 2010 p.
}

Включено до Переліку спеціалізованих наукових видань України (наказ МОН України від 07.10.2016 № 1222) 
Статті цього журналу висвітлюють актуальні проблеми філології та прекладознавства. На матеріалі англійської, української та інших мов науковці - доктори наук з різних міст України та Вірменії розглядають важливі для науки питання когнітивістики і етнопсихолінгвістики; дискурсології; структури і семантики художнього наративу; лінгвокультурології.

Для лінгвістів, викладачів, аспірантів та магістрантів.

\author{
Затверджено рішенням Вченої ради \\ Харківського національного університету імені В.Н. Каразіна \\ (протокол № 5 від 27 квітня 2018 р.)
}

\title{
Головний редактор
}

I.C. Шевченко, докт. філол. нук, професор (Харківський національний університет імені В.Н. Каразіна, Україна), iryna.shevchenko@karazin.ua;

https://orcid.org/0000-0003-2552-5623

https://scholar.google.com.ua/citations?user=uHkA_kgAAAAJ\&hl=ru

\section{Заступник головного редактора}

Є.В. Бондаренко, доктор філол. наук, професор (Харківський національний університет імені В.Н. Каразіна, Україна), ievgeniia.bondarenko.2014@gmail.com;

https://orcid.org/0000-0003-0654-1791 https://scholar.google.com.ua/citations?user=IPdzaq4AAAAJ\&hl

\section{Редактори-консультанти}

Роналд Ленекер, доктор наук, профессор (університет Каліфорнії, Сан-Дієго, США), http://idiom.ucsd.edu/ rwl/

Сюзанна Кеммер, доктор наук, професор, університет Райс, X’юстон, Техас (США), kemmer@rice.edu

\section{Технічний редактор}

М.В. Котов, канд. філол. наук, доцент (Харківський національний університет імені В.Н. Каразіна, Україна), mykhailo.kotov@karazin.ua; https://orcid.org/0000-0001-8327-5197

\section{Відповідальний секретар}

А.Б. Калюжна, канд. філол. наук, доцент (Харківський національний університет імені В.Н. Каразіна, Україна), alevtyna_16@ukr.net; https://orcid.org/0000-0003-4305-5311 https://scholar.google.com.ua/citations?user=p6Fx2PIAAAAJ\&hl=uk

\section{Редакційна колегія}

Донка Александрова, доктор філософії, професор (університет Климента Охридського, Софія, Болгарія), donka_bar@hotmail.com

А.Д. Бєлова, докт. філол. наук, професор (Київський національний університет імені Тараса Шевченка, Україна), profbelova@gmail.com

Л.Р. Безугла, докт. філол. наук, професор (Харківський національний університет імені В.Н. Каразіна, Україна), bezugla@daad-alumni.de; https://scholar.google.com.ua/citations?user=cnY6SDAAAAAJ\&hl=ru

Даніель Вандервекен, доктор філософії, професор (університет Квебека, Труа-Ривьєр, Канада), daniel.vanderveken@gmail.com

О.П. Воробйова, докт. філол. наук, професор (Київський національний лінгвістичний університет, Україна), o.p.vorobyova@gmail.com; http://orcid.org/0000-0001-9039-9737 https://scholar.google.com.ua/citations?user=CEcKrM8AAAAJ\&hl=ru\&oi=ao

С.К. Гаспарян, докт. філол. наук, професор (Єреванський державний університет, Вірменія), sedagasparyan@yandex.com

С.А.Жаботинська, докт. філол. наук, професор (Черкаський національний університет імені Богдана Хмельницького, Україна), ), saz9@ukr.ne; https://scholar.google.ru/citations?user=rEu1MRoAAAAJ\&hl=ru https://independent.academia.edu/SvitlanaZhabotynska

B.I. Карасик, докт. філол. наук, професор (Волгоградський державний педагогічний університет, Росія), vladimir_karasik@mail.ru; researcher ID: C-3975-2016

Є.А. Карпіловська, докт. філол. наук, професор (Інститут української мови Національної академії наук України, Україна),

karpilovska@gmail.com https://scholar.google.com/citations?user=3e9ovmAAAAAJ\&hl=ru

Герхард Коллер, доктор філософії, почесний професор (університет імені Фрідріха Александра, ЕрлангенНюрнберг, Німеччина), gerhard.koller@fau.de 
Г.М. Манаєнко, докт. філол. наук, професор (Ставропольський державний педагогічний інститут, Росія), manaenko@list.ru; https://scholar.google.com.ua/citations?user=Az1SInUAAAAJ\&hl=ru

А.П. Мартинюк, докт. філол. наук, професор (Харківський національний університет імені В.Н. Каразіна, Україна), allamartynyuk@ukr.net; http://orcid.org/0000-0003-2804-3152, https://scholar.google.com.ua/citations?hl=ru\&user=sWGUJgcAAAAJ\&view_op=list_works\&authuser=1

Франциско Д. Матіто, доктор філософії, професор (університет Ла Риоха, Мадрид, Іспанія), fd.matito@unirioja.es

Морін Мінієллі, доктор філософії (університет міста Нью Йорк, США), mo.minielli@me.com; https://orcid.org/0000-0003-0831-8681

C.A. Моісеєва, докт. філол. наук, професор (Бєлгородський державний університет, Росія), moisseeva@bsu.edu.ru; https://orcid.org/0000-0003-0909-3154

O.І. Морозова, докт. філол. наук, професор (Харківський національний уніврситет імені В.Н. Каразіна, Україна), elena.i.morozova@gmail.com; https://scholar.google.com.ua/citations?user=uHN4AZYAAAAJ\&hl=ru

Бен О'Лофлін, професор (університет Лондона, Ройал Холлоу, Велика Британія), ben.oloughlin@rhol.ac.uk

В.Г. Пасинок, докт. пед. наук, професор (Харківський національний університет імені В.Н. Каразіна, Україна), fl@karazin.ua; https://scholar.google.com.ua/citations?user=yEociXAAAAAJ\&hl

А.М. Приходько, докт. філол. наук, професор (Запоріжський національний технічний університет, Україна), aprykhod@mail.ru; https://orcid.org/0000-0001-5051-8711;

https://scholar.google.com/citations?hl=ru\&authuser=1\&user=hZTG75IAAAAJ

https://scholar.google.com.ua/citations?user=9WnGLUcAAAAJ\&hl=ru

О.В. Ребрий, докт. філол. наук, професор (Харківський національний університет імені В.Н. Каразіна, Україна), rebriy@vega.com.ua; http://orcid.org/0000-0002-4912-7489;

В.О. Самохіна, докт. філол. наук, професор (Харківський національний університет імені В.Н. Каразіна, Україна), samokhina.victoria@gmail.com; https://orcid.org/0000-0002-6216-2502; https://scholar.google.com.ua/citations?user=0us2VTAAAAAJ\&hl=ru

Л.В. Солощук, докт. філол. наук, професор (Харківський національний університет імені В.Н. Каразіна, Україна), lsolo@ukr.net; https://scholar.google.com.ua/citations?user=0sKbFhMAAAAJ\&hl=uk

Маргарет Фріман, доктор філософії, почесний професор (Веллі коледж, Лос-Анжелес, США); співдиректор (Мерифілд інститут когніції та гуманітарних наук, Хіт, США), freemamh@lavc.edu

Наталія Чабан, доктор філософії (університет Кентербері, Крайстчерч, Нова Зеландія) natalia.chaban@canterbury.ac.nz

В.С. Чернявська, докт. філол. наук, професор (Санкт-Петербурзький державний політехнічний університет Петра Великого, Росія), tcherniavskaia@rambler.ru; https://orcid.org/0000-0002-6039-6305

\section{Адреса редакційної колегії:}

Україна, 61022, м. Харків, майдан Свободи, 4

Харківський національний університет імені В.Н. Каразіна

Факультет іноземних мов. Тел.: (057) 707-51-44

iryna.shevchenko@karazin.ua

Інтернет-сторінка журналу: http://sites.google.com/site/cognitiondiscourse/home

Текст подано в авторській редакції.

Статті пройшли внутрішнє та зовнішнє рецензування.

Періодичність - 2 випуски на рік

Журнал «Kognitsia, kommunikatsia, diskurs» індексовано в міжнародній базі даних ERIH PLUS (https://dbh.nsd.uib.no/publiseringskanaler/erihplus/periodical/info?id=491014) 
ISSN 2218-2926

МИНИСТЕРСТВО ОБРАЗОВАНИЯ И НАУКИ УКРАИНЫ ХАРЬКОВСКИЙ НАЦИОНАЛЬНЫЙ УНИВЕРСИТЕТ имени В.Н. КАРАЗИНА

\title{
КОГНИЦИЯ, КОММУНИКАЦИЯ, ДИСКУРС
}

\section{Направление «Филология»}

\author{
№ 16 \\ Международный электронный сборник научных трудов
}

Основан в 2010

Включен в Перечень специализированных научных изданий Украины (приказ МОН Украины от 07.10.2016 № 1222) 
Статьи этого журнала освещают актуальные проблемы филологии и переводоведения. На материале английского, украинского и других языков ученые - доктора наук из разных городов Украины и Армении - рассматривают важные для науки вопросы когнитивистики и этнопсихолингвистики; дискурсологии; структуры и семантики художественного нарратива; лингвокультурологии.

Для лингвистов, преподавателей, аспирантов и магистрантов.

\author{
Утверждено решением Ученого совета \\ Харьковского национального университета имени В.Н. Каразина \\ (протокол № 5 от 27 апреля 2018 г.)
}

\title{
Главный редактор
}

Ирина Семеновна Шевченко, докт. филол. наук, профессор (Харьковский национальный университет имени В.Н. Каразина);

iryna.shevchenko@karazin.ua, https://orcid.org/0000-0003-2552-5623;

https://scholar.google.com.ua/citations?user=uHkA_kgAAAAJ\&hl=ru

\section{Заместитель главного редактора}

Евгения Валериевна Бондаренко, докт. филол. наук, профессор (Харьковский национальный университет имени В.Н. Каразина), ievgeniia.bondarenko.2014@gmail.com https://scholar.google.com.ua/citations?user=IPdzaq4AAAAJ\&hl

\section{Редакторы-консультанты}

Рональд Ленекер, доктор наук, профессор, университет Каліфорнии, Сан-Диего, США; http://idiom.ucsd.edu/ rwl/

Сюзанна Кеммер, доктор наук, профессор, университет Райс, Хьюстон, Техас (США); kemmer@rice.edu

\section{Технический редактор}

М.В. Котов, канд. филол. наук (Харьковский национальный университет имени В.Н. Каразина, Украина) mykhailo.kotov@karazin.ua; mykhailo.kotov@gmail.com; https://orcid.org/0000-0001-8327-5197

\section{Ответственный секретарь}

А.Б. Калюжная, канд. филол. наук (Харьковский национальный университет имени В.Н. Каразина, Украина), alevtyna_16@ukr.net;

https://orcid.org/0000-0003-4305-5311; https://scholar.google.com.ua/citations?user=p6Fx2PIAAAAJ\&hl=uk

\section{Редакционная коллегия}

Донка Александрова, доктор философии (университет Климента Охридского, София, Болгария), donka_bar@hotmail.com

Л.Р. Безуглая, докт. филол. наук, профессор (Харьковский национальный университет имени В.Н. Каразина, Украина),

bezugla@daad-alumni.de; https://scholar.google.com.ua/citations?user=cnY6SDAAAAAJ\&hl=ru

А.Д. Белова, докт. филол. наук, профессор (Киевский национальный университет имени Тараса Шевченко, Украина), profbelova@gmail.com

Даниэль Вандервекен, доктор философии (университет Квебека, Труа-Ривьер, Канада), daniel.vanderveken@gmail.com

О.П. Воробйова, докт. филол. наук, профессор (Киевский национальний лингвистический университет, Украина), o.p.vorobyova@gmail.com; http://orcid.org/0000-0001-9039-9737; ttps://scholar.google.com.ua/citations?user=CEcKrM8AAAAJ\&hl=ru\&oi=ao

С.К. Гаспарян, докт. филол. наук, профессор (Ереванский государственный университет, Армения), sedagasparyan@yandex.com

C.А.Жаботинская, докт. филол. наук, профессор (Черкасский национальный университет имени Богдана Хмельницкого, Украина), saz9@ukr.ne; https://scholar.google.ru/citations?user=rEu1MRoAAAAJ\&hl=ru https://independent.academia.edu/SvitlanaZhabotynska

В.И. Карасик, докт. филол. наук, профессор (Волгоградский государственный педагогический университет, Россия), vladimir_karasik@mail.ru; researcher ID: C-3975-2016

Е.А. Карпиловская, докт. филол. наук, профессор (Институт украинского языка Национальной академии наук Украины, Украина),

karpilovska@gmail.com; https://scholar.google.com/citations?user=3e9ovmAAAAAJ\&hl=ru 
Генхард Коллер, доктор философии, почетный профессор (университет имени Фридриха Александра, Эрланген-Нюрнберг, Германия), gerhard.koller@fau.de

Г.Н. Манаенко, докт. филол. наук, профессор (Ставропольський государственный педагогический институт, Россия), manaenko@list.ru; https://scholar.google.com.ua/citations?user=Az1SInUAAAAJ\&hl=ru

А.П. Мартынюк, докт. филол. наук, профессор (Харьковский национальный университет имени B.Н. Каразина, Украина), allamartynyuk@ukr.net;

http://orcid.org/0000-0003-2804-3152,

https://scholar.google.com.ua/citations?hl=ru\&user=sWGUJgcAAAAJ\&view_op=list_works\&authuser=1

Франциско Д. Матито, доктор философии, профессор (университет Ла Риоха, г. Мадрид, Испания), fd.matito@unirioja.es

Морин Миниелли, доктор философии (университет города Нью Йорк, США), mo.minielli@me.com; https://orcid.org/0000-0003-0831-8681

C.А. Моисеева, докт. филол. наук, профессор (Белгородский государственный университет, Россия), moisseeva@bsu.edu.ru; https://orcid.org/0000-0003-0909-3154

Е.И. Морозова, докт. филол. наук, профессор (Харьковский национальный университет имени В.Н. Каразина, Украина), elena.i.morozova@gmail.com; https://scholar.google.com.ua/citations?user=uHN4AZYAAAAJ\&hl=ru

Бен О'Лофлин, профессор (университет Лондона, Ройал Холлоу, Великобритания), ben.oloughlin@rhol.ac.uk

В.Г. Пасынок, докт. пед. наук, профессор (Харьковский национальный университет имени В.Н. Каразина, Украина) fl@karazin.ua, https://scholar.google.com.ua/citations?user=yEociXAAAAAJ\&hl

А.Н. Приходько, докт. филол. наук, профессор (Запорожский национальный технический университет, Украина), aprykhod@mail.ru; https://orcid.org/0000-0001-5051-8711;

https://scholar.google.com/citations?hl=ru\&authuser=1\&user=hZTG75IAAAAJ

https://scholar.google.com.ua/citations?user=9WnGLUcAAAAJ\&hl=ru

А.В. Ребрий, докт. филол. наук, професор (Харьковский национальный университет имени В.Н. Каразина, Украина), rebriy@vega.com.ua;

http://orcid.org/0000-0002-4912-7489; https://scholar.google.com/citations?user=ak5-nc8AAAAJ\&hl=en

В.А. Самохина, докт. филол. наук, профессор (Харьковский национальный университет имени В.Н. Каразина, Украина), samokhina.victoria@gmail.com; https://orcid.org/0000-0002-6216-2502; https://scholar.google.com.ua/citations?user=0us2VTAAAAAJ\&hl=ru

Л.В. Солощук, докт. филол. наук, профессор (Харьковский национальный университет имени В.Н. Каразина, Украина),

lsolo@ukr.net; https://scholar.google.com.ua/citations?user=0sKbFhMAAAAJ\&hl=uk

Маргарет Фриман, доктор философии, почетный профессор (Вэлли Колледж, Лос-Анжелес); со-директор (Мэрифилд институт когниции и гуманитарных наук, Хит, США), freemamh@lavc.edu

Наталья Чабан, доктор философии (университет Кентербери, Крайстчерч, Новая Зеландия), natalia.chaban@canterbury.ac.nz

В.Е. Чернявская, докт. филол. наук, профессор (Санкт-Петербургский государственный политехнический университет Петра Великого, Россия), tcherniavskaia@ rambler.ru; https://orcid.org/0000-0002-6039-6305

\section{Адрес редакционной коллегии:}

Украина, 61022, г. Харьков, пл. Свободы, 4

Харьковский национальный университет имени В.Н. Каразина

Факультет иностранных языков Тел.: (057) 707-51-44

iryna.shevchenko@karazin.ua

Інтернет-страница журнала: http://sites.google.com/site/cognitiondiscourse/home

Текст дается в авторской редакции. Статьи прошли внутреннее и внешнее рецензирование.

Периодичность - 2 выпуска в год.

Журнал «Kognitsia, kommunikatsia, diskurs» индексирован в международной базе данных ERIH PLUS (https://dbh.nsd.uib.no/publiseringskanaler/erihplus/periodical/info?id=491014)

(C) Харьковский национальный университет имени В.Н. Каразина, оформление, 2018 


\section{CONTENTS}

Bondarenko I.V.

KHARKIV LINGUISTIC SCHOOL. HERITAGE.

ALEXANDER POTEBNJA

Brutian L.G.

AMERICAN PLACE NAMES AS THE REFLECTION

OF AMERICAN MENTALITY

Galutskikh I.A.

LINGUOPOETICS OF CORPORALITY IN LITERARY TEXTS

OF ENGLISH MODERNISM AND POSTMODERISM ...

Leshchenko H.

NARRATIVE TENSION WITHIN THE FRAMEWORK

OF COGNITIVE MODELING

Rebrii O.V.

TRANSLATION AS A MEANS OF CONSTRUCTING CULTURES:

PHILOSOPHICAL FOREGROUNDING 64

Tsapiv A.O.

MODELS OF NARRATION IN LITERARY TEXSTS FOR CHILDREN

(Case study of Norman Lindsay's fairy tale "The Magic Pudding") 72

GUIDELINES FOR CONTRIBUTORS 


\section{MICT}

Бондаренко Є.В.

ХАРКІВСЬКА ЛІНГВІСТИЧНА ШКОЛА. СПАДЩИНА.

ОЛЕКСАНДР ПОТЕБНЯ

Брутян Л.Г.

АМЕРИКАНСЬКІ ТОПОНІМИ ЯК ВІДОБРАЖЕННЯ

АМЕРИКАНСЬКОЇ МЕНТАЛЬНОСТІ

Галуцьких I.A.

ЛІНГВОПОЕТИКА ТІЛЕСНОСТІ В ХУДОЖНІХ ТЕКСТАХ

АНГЛІЙСЬКОГО МОДЕРНІЗМУ ТА ПОСТМОДЕРНІЗМУ

Лещенко Г..

НАРАТИВНА НАПРУЖЕНІСТЬ У СВІТЛІ КОГНІТИВНОГО

МОДЕЛЮВАННЯ

Ребрій О.В.

ПЕРЕКЛАД ЯК ЗАСІБ КУЛЬТУРОТВОРЕННЯ:

ФІЛОСОФСЬКЕ ОБГРУНТУВАННЯ

А.О. Цапів

МОДЕЛІ НАРАЦІЇ У ХУДОЖНІХ ТЕКСТАХ ДЛЯ ДІТЕЙ

(на матеріалі казки Нормана Ліндсі «Чарівний пудинг»)

РЕКОМЕНДАЦІЇ АВТОРАМ $З$ ОФОРМЛЕННЯ СТАТЕЙ 


\section{СОДЕРЖАНИЕ}

Е.В. Бондаренко

ХАРЬКОВСКАЯ ЛИНГВИСТИЧЕСКАЯ ШКОЛА. НАСЛЕДИЕ.

АЛЕКСАНДР ПОТЕБНЯ.

Л.Г. Брутян

АМЕРИКАНСКИЕ ТОПОНИМЫ КАК ОТРАЖЕНИЕ

АМЕРИКАНСКОЙ МЕНТАЛЬНОСТИ

И.А. Галуцких

ЛИНГВОПОЕТИКА ТЕЛЕСНОСТИ В ХУДОЖЕСТВЕННЫХ ТЕКСТАХ

АНГЛИЙСКОГО МОДЕРНИЗМА И ПОСТМОДЕРНИЗМА

Лещенко А.

НАРРАТИВНАЯ НАПРЯЖЕННОСТЬ В СВЕТЕ КОГНИТИВНОГО

МОДЕЛИРОВАНИЯ

Ребрий А.В.

ПЕРЕВОД КАК СРЕДСТВО КУЛЬТУРООБРАЗОВАНИЯ:

ФИЛОСОФСКОЕ ОБОСНОВАНИЕ

Цапив А.O.

МОДЕЛИ НАРРАЦИИ В ХУДОЖЕСТВЕННЫХ ТЕКСТАХ ДЛЯ ДЕТЕЙ

(на материале сказки Нормана Линдси «Волшебный пудинг»).

РЕКОМЕНДАЦИИ АВТОРАМ ПО ОФОРМЛЕНИЮ СТАТЕЙ 
UDC 81-11

\section{KHARKIV LINGUISTIC SCHOOL. HERITAGE. ALEXANDER POTEBNJA Ievgeniia V. Bondarenko (Kharkiv, Ukraine)}

I.V. Bondarenko. Kharkiv linguistic school. Heritage. Alexander Potebnja. The article focuses on the scientific heritage of Alexander Potebnja as one of the founders of Kharkiv linguistic school. Potebnja's seminal books and articles that among many other issues address language origin, human consciousness, and semantics of linguistic units are considered as milestones in the development of state-of-the-art humanities. The article reads his three tenets in terms of philosophy of language and cognitive linguistics. The first tenet concerns correlation between language and thought as a way of accounting for language origin and linguistic abilities of the human. The latter that uses language to communicate his world perceptive experience is ascribed a two-facet nature as both an individual and a nation. This tenet is viewed as one anticipating the underpinning principles of cognitive linguistics and theory of the national construal of the world. The second tenet concerns mental evolution of humanity. Potebnja sees it as a contiguity of image and meaning that diverge evolving in myth, poetry and prose. This tenet is considered as an anticipation of Popper's Evolutionary Epistemology and Westman's theory of the ontogenesis of the psyche. The third Potebnja's tenet focuses on the symbolism of linguistic units. The exclamation and the word are juxtaposed in terms of their internal and external forms. The word and the exclamation are analyzed as signs that render meaning by way of, correspondingly, either indicating to it or symbolizing it. These features suggest conceptual parallelism with Pierce's semiotic trichotomy of icon, index and symbol.

Key words: language origin, linguistic ability of the human, mental evolution of humanity, myth, poetry, prose, symbolism of linguistic units

Є.В. Бондаренко. Харківська лінгвістична школа. Спадщина. Олександр Потебня. Статтю присвячено науковій спадщині Олександра Опанасовича Потебні як одного із засновників харківської лінгвістичної школи. Його відомі книги та статті, які, серед багатої інших питань, розглядали проблеми походження мови, свідомості людини та семантики мовних одиниць, презентовано як установчі у подальшому розвитку новітніх напрямів гуманітарної науки. Три постулати О.О. Потебні тлумачаться у статті в термінах філософії мови та когнітивної лінгвістики. Перший постулат стосується співвідношення між мовою та думкою, через яке пояснюється походження мови та мовних здібностей людини. Остання, що використовує мову для комунікації власного перцептивного досвіду світопізнання, на переконання вченого, має двоїсту природу та постає або як індивідуальність, або як нація. Цей постулат розглядається у світі сучасних базових принципів когнітивної лінгвістики та теорії національної картини світу. Другий постулат тлумачить процес ментальної еволюції людства. О.О. Потебня розуміє іiі у межах образу та значення, природа яких змінюється від спільної до абсолютно різної залежно від середовища їхнього існування, - міфу, поезії чи прози. Цей постулат О.О. Потебні аналізується як передбачення еволюційної епістемології К. Поппера та теорії онтогенезу людської психіки Г. Вестмана. Третю тезу О. Потебні зосереджено на символізмі лінгвістичних одиниць. Вигук та слово співставлено з точки зору взаємозв'язку їхніх зовнішньої та внутрішньої форм. Обидві одиниці постають як знаки, що передають значення, відповідно, або вказуючи на нього, або символізуючи. Ці риси дозволяють стверджувати про концептуальну суголосність теорій О.О. Потебні та семіотики Ч. Пірса з його трихотомією ікони, індексу та символу.

Ключові слова: ментальна еволюція людства, міф, мовна здатність людини, поезія, проза, походження мови, символізм мовних одиниць

C Bondarenko I.V., 2018 
Е.В. Бондаренко. Харьковская лингвистическая школа. Наследие. Александр Потебня. Статья посвящена научному наследию Александра Афанасьевича Потебни как одного из основателей харьковской лингвистической школы. Его известные книги и статьи, которые, среди многих других вопросов, освящали проблемы происхождения языка, сознания человека и семантики языковых единиц, представлены как основополагающие для развития новейших направлений гуманитарной науки. Три постулата А. А. Потебни трактуются в статье с точки зрения философии языка и когнитивной лингвистики. Первый постулат - о взаимосвязи языка и мысли, посредством которой объясняется происхождение языка и языковых способностей человека. Последний, используя язык для коммуникации собственного перцептивного опыта мировосприятия, по убеждению ученого, обладает двойственной природой как индивидуальность и как нация. Этот постулат рассматривается в свете базовых принципов когнитивной лингвистики и теории национальной картины мира. Второй постулат касается процесса ментальной эволюции человечества. А.А. Потебня объясняет её через корреляцию образа и значения, природа которых изменяется от подобной до принципиально различной в зависимости от среды, в которой они находятся, - мифа, поэзии или прозы. Этот постулат А.А. Потебни рассматривается как научное предвидение эволюционной эпистемологии К. Поппера и теории онтогенеза человеческой психики Х. Вестмана. Третий тезис А.А. Потебни касается символизма лингвистических единиц. Междометие и слово сопоставляются с точки зрения взаимосвязи их внешней и внутренней форм. Обе единицы анализируются как знаки, которые передают значение, соответственно, либо указывая на него, либо символизируя его. Эти свойства языковых знаков позволяют говорить о концептуальной подобности теорий А.А. Потебни и семиотики Ч. Пирса с его трихотомией иконы, индекса и символа.

Ключевые слова: ментальная эволюция человечества, миф, поэзия, проза, происхождение языка, символизм языковых единиц, языковые способности человека

\section{Introduction}

This article has been conceived as one commencing the series of dedications to the founders of Kharkiv linguistic school. These prominent linguists, whose seminal works often stemmed from their congenial surmise, since linguistics lacked appropriate means for supporting them, nonetheless, gave an impetus to the development of new theories and trends in modern linguistics. In the first review, I concentrate on the personality and scientific works of Alexander Potebnja. My ultimate aim is to identify his ideas that, on the one hand, revolutionized linguistic theory in his contemporary period, and, on the other, may be regarded as a milestone in forming new tendencies in modern linguistic science, cognitive linguistics in particular. Pursuing this aim, I address the following issues that nowadays nurture state-of-the-art linguistics. Firstly, it is Potebnja's conception of thought vs. language as a way of accounting for language origin. He develops it to identify the national diversity of languages, in particular, Ukrainian as the means of rendering and implementing national mentality, or spirit in his terms. In Potebnja's elaboration and criticizing Humboldtian theory of language origin, I see an underpinning of the theory of the national world construal (Hunnings 1988; Kornilov 2003; Popova \& Sternin 2015; Taylor 1995; Wittgenstein 2003 (1958)). Secondly, I analyze Potebnja's tenet of mythological mentality implemented in language, which gave rise to the theory of mental evolution of humanity. It was elaborated as subsequent transformations from myth to poetry that is followed by prose (as language of science). In the article, I read one of the central principles of cognitive linguistics as a corollary of this hypothesis. This principle entails diachronic approach to language and cognition in their co-reference or, in modern terms, Evolutionary Epistemology (Munz 2007; Popper 2002 (1957)), Heinz Westman's theory of the ontogenesis of the psyche (Westman 1983). Finally, however, far from exhausting the list of Potebnja's theories that play pivotal role in modern linguistic science, it is his elucidation of the symbolism of language units. Later it was elaborated into the psycholinguistic theory of literature (Fizer 1986). I consider this Potebnja's theory as a parallelism of Pierce's linguistic semiotics (Liszka 1996). 


\section{Potebnja's tenet of language vs. thought and national spirit}

In his main books, Language and Thought (1999 (1892)) and Word and Myth (1989), Potebnja considers Humboldt's idea that language is a device for creating thought (Das bildende Organ des Gadanken). Completely sharing it, Potebnja, however, acknowledges Humboldt's limitations in reading the origin of language as both a God's gift and a type of emanation of the national spirit. He argues that if, by Humboldt, language is immanently free, as this freedom is godly, language and spirit are supposed to be collateral as having common celestial descend. Potebnja's view of language diverges from that of Humboldt's. The former completely rejects Humboldtian metaphysics that, in his opinion, fails to solve the contradiction of the godly and the human in accounting for language origin. Moreover, for Potebnja, Humboldtian system looks inefficient as far as it stands that language and spirit are immanently interdependent and therefore, it is impossible to consider them as separate entities. Therefore Potebnja develops three capital counter arguments (here and henceforth translation mine):

The condition of common celestial descend stays just a void condition, because the researcher himself, identifying differences in languages building, accounts for them by differences in national character, which contradicts his own theoretical statement. If language is nurtured by spirit then, firstly, it cannot be independent of spirit, it is bound by spirit rather than godly free; secondly, it does not need to be common with spirit, language is different from spirit; thirdly, language descend from national spirit is exclusively human (Potebnja 1999: 36; emphasis added).

This discussion entails at least three principles that look vital for cognitive linguistics.

The first one concerns the nature of relations between language and spirit. Significantly, Potebnja objects to Humboldt's reading of the very sense of the notion of spirit that, in his opinion erroneously, encompasses all aspects of human spiritual life:

Considering the word spirit that plays a pivotal role in Humboldtian system, in the most general and probably absolutely wrong sense of the human being's spiritual life taken by and large, we will question ourselves: to what extent this life and language are inseparable? To answer this question, one will have to eliminate the contiguity (but not interrelation) with language of senses and will that is rendered by word, as <much as> they comprise the content of our thought (Potebnja 1999: 41; emphasis added).

Here, Potebnja evidently identifies the sphere of thoughts viewing the term spirit as modern equivalent of the human cognitive mechanism. Potebnja develops this thesis in an argument that thought itself may not involve language as its integral part but mainly exists prior to or beyond language:

A child does not speak up to a certain age, but in a certain way thinks, that is perceives through senses, besides in a more perfect way than an animal, recollects his perception and even partly generalizes it. In the course of his development, when the human being already has a full command of language, immediate sensitive impressions either exist prior to their union with word or even never come to this union. <... Artistic thought of a painter, sculpturer, musician is not rendered by word and is implemented beyond it, though presupposes an advanced level of development, which is nurtured exclusively by language. $<\ldots>$ Finally, in mathematics, the science that is most perfect in form, speaking human rejects word and makes the most sophisticated statements using conventional signs.

All this is the evidence that the realm of language lies far from coincidence with the realm of thought (Potebnja 1999: 41; emphasis added). 
This argument manifests the second pivotal principle for cognitive linguistics: the primary role of cognition in forming linguistic ability of the human being. It completely agrees with one of the major hypotheses as "guiding the cognitive linguistic approach to language" (Croft, Cruse 2004: 1):

$<\ldots>$ language is not an autonomous cognitive faculty. The basic corollaries of this hypothesis are that the representation of linguistic knowledge is essentially the same as the representation of other conceptual structures, and that the processes in which that knowledge is used are not fundamentally different from cognitive abilities that human beings use outside the domain of language (Croft, Cruse 2004: 2).

At the same time, Potebnja following Humbold endorses the role of language in the spiritual activity of the human being. Using Humboldt's own arguments, Potebnja identifies the role of word as an indispensable element of human spiritual activity that makes it conscious:

$<\ldots>$ to become conscious, spiritual activity needs word, it emerges as an additional element when all other conditions for transition to conscious activity are already available. Therefore, considering spirit as conscious intellectual activity that entails notions, which may be formed exclusively by word, we will see that spirit is impossible without language $<\ldots>$ (Potebnja 1999: 42; emphasis added).

I see a great significance of this argument for cognitive linguistics. The notion here is a token of conscious activity of the human being, which is implemented in word, on the one hand, and modern reading of the concept by Langacker (1987), Stepanov (2004), Nikitin (2007), Evans (2009), on the other, converge in many respects. Words (their meanings) by Evans, are associated with lexical concepts implemented in words, whereas by Nikitin and Stepanov, the notion is a core element of the conceptual structure that is implemented in a word meaning. C.f.:

$<\ldots>$ language serves as a mediator between the world of perceived objects and a perceiving person and in this sense combines objectivity and subjectivity. As for language subjectivity towards the perceived, it is even more obvious and empirically tested by the fact that word value (e.g. tree) is neither equal to even the most elementary notion of the object nor to the limitless features of the object itself. The explanation is the following. Word is formed from subjective perception and is not an imprint of the object itself but that of its reflection in the soul (Potebnja 1989: 41-42; emphasis added).

Potebnja sees immediate correlation among notions in the process of cognition. He identifies the notion as "a feature that a word uses to express a thought" (Potebnja 1989: 444). He insists that the notions seemingly irrelevant to the situation render the way the human being coherently perceives the world. Potebnja distinguishes the root of such correlations in the etymology of words implementing them. In this process, the human being forms a number of notions significant for his existence. These notions are implemented in words and their (grammatical) relations, which in the long run comprise language.

In this statement, I see the underpinning of the third principle of cognitive psychology and linguistics that perception of the world entails construal (Taylor 1995). In his attempt to identify language origin and the nature of linguistic meaning (word value in his terms), Potebnja rejects Humboldtian metaphysics. He suggests psychology as an ultimate realm of developing the theory of language origin and evolution:

$<\ldots>$ the godly nature of language may be set aside, and the issue of its origin becomes the issue of the spiritual life phenomena that precede language, the issue of the laws of its 
formation and evolution, as well as that of its influencing the following spiritual activity, that is an exclusively psychological issue (Potebnja 1999: 43; emphasis in original).

Potebnja develops this thesis considering language as a product of nation. Here, he delineates the objects of ethno-psychology as well as that of the theory of the national construal of the world (Kornilov 2003; Popova \& Sternin 2015):

$<\ldots>$ developed by linguistics, the laws of language as the product of nation will be augmented by currently forming trend in psychology that will focus on the coordination of personal and national evolution (Potebnja 1999: 53; emphasis added).

Significantly, Potebnja delegates to ethno-psychology, psychology of nations in his terms, a special mission in science. This is to provide a tool for identifying differences in features and structures of languages, which he considers natural:

$<\ldots>$ psychology of nations should demonstrate the possibility of differentiation among natures and structures of languages, this differentiation being the consequence of the common laws of the life of nations. Therefore, what seems optimal to us is the branch of science that would articulate the respect to nations as a natural and justifiable phenomenon rather than consider them as an anomaly, like logical grammar offers (Potebnja 1999: 54; emphasis added).

It is worth noting that Potebnja put great emphasis on the idea of the respect to nations and their right to use their language. In Russian Empire, for him, Ukrainian born and bred, his native tongue was the Malorussian language (from Malorussia or Little Russia, the derogative name of Ukraine at that period of time). He addressed various issues of the Ukrainian language in his numerous papers and articles. In his letter to the Czech linguist Patera in 1886, he identifies the role of Ukrainian in his scientific career the following way:

The circumstances of my life conditioned the fact that in my scientific activity my point of departure, which was evident or sometimes not really evident for others, was the Malorussian language and Malorussian folk culture. If I had not been endowed by this departing point and my feeling associated with it, I believe, I would never practice science (Potebnja 1962: 93).

In his works, he more than once emphasized that hostility to a national language and attempts to suppress its development to appease the dominating culture is fruitless:

One may not wish life to a certain language if one is persuaded of its inefficiency for human existence. Such considerations make us exterminate pests to give way to good plants. <...> One may be hostile to a language because one acknowledges its powers and loathes its competition with another language that one defends. However, both the neglect and the fear of folk tongues on behalf of the advocates of the unconditional reign of one literary language equally lack sense (Potebnja 1962: 76-77).

Therefore, Potebnja's ideas concerning language origin and its relevance to the processes of individual and national world perception were far ahead of his time and in many respects anticipated the basic postulates of cognitive linguistics and ethno-psychology. They are the following. Firstly, it is the pivotal role of cognition as an impetus to language emergence and evolution. Secondly, it is the role of cognitive mechanisms of the human being in developing his language abilities. Thirdly, it is the nature of the human perception of the world as a construal that entails individual and national 
features. The latter may be considered as an underpinning of the theory of the national construal of the world specifically implemented in language. This thesis provides an argument in favor of independent existence and development of the national linguistic culture and literary arts.

\section{Potebnja's tenet of mythological mentality implemented in language}

In his book Word and Myth, Potebnja considers, in terms of modern linguistics, the evolution of the types of world perception implemented in language or rather different artistic genres. The initial type, as he sees it, is mythological. Potebnja identifies myth as a formula that is further implemented in word developed in the work of art. Mythological thinking stems from the most primitive and naïve world perception that the early or uneducated human being possessed. It is significant that these means, i.e. word or work or art, though they make this perception objective, are irrelevant to the notion of truth or real state of things. This type of perception lacks the internal feeling that assists in identifying the real state of things. To illustrate this type of perception, Potebnja uses his own recollections of the market performance when the audience attacked actors taking them for real villains (1989: 246). However, he does not exclude the possibility of some elements of mythological mentality in the consciousness of a well-educated person.

The most significant thesis in this respect is that considering mythological thinking is indispensable for the diachronic view of the intellectual evolution of humanity and the theory of literature as its immanent product. Potebnja focuses on myth as a most popular object of systematic research in his time. He accounts for this in philosophical sense, as far as, in his opinion, the human being's ontological interest to its own nature has transformed:

This is because the main question of self-cognition "What am I?" for modern human being transforms into "How did I come by my current qualities?" The urge to self-cognition entails one's understanding of the relevance of one's self to the present and past of the humanity, of dependence between culture and its absence. All this gave an impetus to the research of objective implementations of human thought, language and literature among them (Potebnja 1989: 249; emphasis in original)

In Word and Myth, Potebnja focuses on myth as an implementation of, in modern terms, a special type of cognition. Comparing myth with poetry, he maintains that on linguistic level they are almost coterminous. He believes that the clue to their distinction should be looked in the realm of consciousness, whose 'watchful eye', in his own words, is capable of distinguishing myth from poetry:

Myth is different from poetry in its narrow sense concerning poetic works, which emerged later. All the difference between myth and this later poetry stems from the attitude of consciousness to the elements of each. Ignoring this watchful eye, i.e. considering them exclusively as verbal phenomena, one would not distinguish them (Potebnja 1989: 259; emphasis added).

Potebnja develops this idea comparing myth and poetry as specific ways of world perception opposed to science. In this argumentation, the key terms are image and meaning and the nature of correlation between them. Potebnja's theory stands that myth represents the act of early consciousness. The relevance between image and meaning is imminent for both myth and later poetry. However, in myth, the figurative meaning of image is axiomatic and unintended:

(i) Myth belongs to the realm of poetry in the wide meaning of this word. Like any poetic work, $\langle\ldots\rangle$ it consists of image and meaning, whose relevance is not to be tested as science requires, but is immediately persuasive or taken for granted $<\ldots>$ In myth, one who creates 
the figurative value of image is not aware of it, image is completely extrapolated in meaning. In other words, myth is a verbal rendering of perception when the explaining image with exclusively subjective meaning is tagged as objective, i.e. as real in the realm of the explained (Potebnja 1989: 259; emphasis in original).

In poetry, image is viewed as a temporary device of creating meaning. By Potebnja, as soon as the figurative meaning has been distinguished as such, the unity of image and meaning disintegrates:

In a later poetic work, image is no more than a device for creating (perception of) meaning, a device that disintegrates into elements, loses its integrity as a whole every time when it has fulfilled its purpose, in other words, in poetry, image has exclusively figurative meaning. $<\ldots>$ Therefore, in mythological thinking, two halves of the statement (in particular, image and meaning) are more similar than in poetic one. The transformation of the relevance between image and meaning leads from myth to poetry, and further, from poetry to prose and science (Potebnja 1989: 259; emphasis added).

In science, which Potebnja immediately relates to prose, image is a tool of implementing more sophisticated (in comparison with myth and poetry) structures of thought. These structures arise from the specific way of world perception that Potebnja identifies as modern human's ability to perform analysis and practice critical thinking. These immanent features of scientific perception are continuously utilized to challenge the relevance of image and meaning:

Modern person uses a poetic image as a means for construing and re-construing a new thought. To a certain extent, this process stems from his ability of scientific thinking, i.e. his ability to analyze and criticize. Analysis is disintegration of concrete (complex) perceptions and construal (creations of thoughts, in Potebnja's terms) into mutually exclusive realms to put them together again but in a way more convenient for thought. In its advance, this analysis is accompanied by building up an ability to question the truthfulness of this construal. Every new construal (combination of thought) serves both an underpinning for testing previous construals and an impetus to the search of new perceptions, comparing and agreeing them with the previous ones (Potebnja 1989: 244; emphasis added).

Most significantly, Potebnja concludes that such observation of the nature of the human thought evolution provides a wide historical perspective. In its terms, he maintains that the human thought continuously creates a specific construal of the world (the human world, in Potebnja's terms) that is exclusively subjective. However, this subjectivity changes nature every time the obsolete view of the world transforms into the state-of-the-art one:

Consolidating and generalizing the results of such work of human thought serves an underpinning for history. It stems from an idea that the human world is always currently subjective; that this world is a string of changing worldviews whose truthfulness is nurtured by their topicality; that we can compare our present view as a true one with a previous view as a false one; that we presently lack means for testing our view (Potebnja 1989: 244; emphasis added).

I see this statement as an anticipation of Karl Popper's Evolutionary Epistemology. The latter contends that "selection is the generator and maintainer of the reliability of our senses and cognitive mechanisms, as well as the "fit" between those mechanisms and the world" (SEP; emphasis added). One of the key terms of Popper's theory is the growth of human knowledge (c.f. Potebnja's string of changing worldviews): 
The course of human history is strongly influenced by the growth of human knowledge (Popper 2002 (1957): xii).

Evidently, in his theory, Popper mainly focuses on scientific knowledge, however, the idea of an evolutionary approach to human's world perception and its results rendered in language look conceptually analogous (also see Peter Munz [2007]). The elaboration of this idea can also be traced in Heinz Westman's theory of the ontogenesis of the psyche (1983). This theory stands that the evolution of human's world perception is featured in mythological world view of the Bible.

To conclude this part, Potebnja's tenet of the evolution of mentality accounts for the ways of human world perception as a correlation of image and meaning implemented in language. This correlation is of paramount importance, since it is considered in terms of correspondence to real state of things. In mythological view, image and meaning converge, this extrapolation being axiomatically true. In poetic rendering of world perception, image is a tool of figurative language. Poetic type of viewing the world departs from the temporary or purely practical correlation of image and meaning. In science that Potebnja immediately associates with prose, the correlation of image and meaning is continuously tested, as this type of knowledge is only relatively true for a certain stage of human thought evolution. This Potebnja's idea, as I see it, conceptually anticipates Karl Popper's theory of Evolutionary Epistemology and Heinz Westman's theory of the ontogenesis of the psyche.

\section{Potebnja's tenet of the symbolism of language units}

One of the most popular Potebnja's tenets in the realm of poetics and aesthetics is immediately associated with his scientific heritage. It accounts for the semantic isomorphism of sounds (exclamations), and words in terms of the immanent correlation between the historically evolving human perception and language, which implements its results. Elaborating this theory, Potebnja departs from the supposition that the need to communicate perceptive experience of the primeval human was an impact to using primitive sounds or exclamations. This leads him to the argument that has stayed pivotal for semantic research within the last two centuries. In terms of modern cognitive science, it stands that construing the internal form of a linguistic unit, or its meaning, is subject to the uniform regularities rooted in human psyche.

Potebnja obviously distinguishes the internal form of the sound from that of the word. He considers the sound or the exclamation as a milestone in the evolution of human perception rendered in language. For him, the sound is a means of communication on an onomatopoetic stage of language history. He insists on this term since the sound used by the humans rendering certain experience differs from that produced by nature or animals in as much as the former is immanently symbolic:

The indefinite nature of the exclamation lies in the fact that it does not have meaning of the kind the word does. But for language obstacles, we wouldn't be able to state that an exclamation caused by fear means fear, that is the thought about it implemented in the word fear, similarly, we wouldn't maintain that a blush on one's face means confusion. As an apex of an hour and minute clock hands on the mark 12 does not mean 12 o'clock but only indicates at this time, as shiver and fever, as well as high or low pulse rate do not mean disease but only serve symptoms for doctors, to the observer, exclamations present senseless in themselves features of one's soul states, whereas in the word he deals with a readymade thought (Potebnja 1999: 84; emphasis added).

Potebnja's features of one's soul states comparable with modern term perceptive experience is a point in his argument for language symbolism. This term is immediately associated with Pierce's semiotic system and its trichotomy of icon, index and symbol. Following Potebnja's logics, exclamations demonstrate contiguity between external form as a primitive sound and internal form 
as a main means of rendering human's perceptive experience. This feature is known as inherent in indices in terms of Pierce's system:

If the presentative characteristics of the sign are contiguous with the object and it thereby establishes its correlation with that object primarily by that means, then the sign is called an index (Lizska 1996: 117).

The internal form of the word, on Potebnja's definition, is a much more complex structure that demonstrates at least three features. The first is, opposite to sound, the meaning that deals with a more or less completely formed idea of the object rendered by word:

Internal form of word is the correlation of the thought content to consciousness; it demonstrates how a person sees his own thought (Potebnja 1999: 98).

On the other hand, whereas one and the same sound may tag any possible perceptive experience, the word has a stable correlation of external and internal form:

A thought once referred to a word, is triggered in one's consciousness by the sounds of this word (Potebnja 1999: 82).

Potebnja develops this idea and arrives at the conclusion that in every utterance word may have a different sense; however, the core of its meaning stays immutable as it refers its user to the same notion:

In conversation, everyone understands the word in his own way, but its external form suggests an objective thought that does not depend on the way one understands it. <.. > Word recurrence is just the other facet of its ability to have objective meaning for one and the same person (Potebnja 1999: 82; emphasis added).

This argument suggests the second feature of the word's internal structure as its ability to render the notion. Potebnja argues that the word is a device of implementing the notion as a kind of construal, in modern terms. In the word, the notion is clearly structured and systematic, referred to the other notions or attributes, etc.:

Clarity (differentiation of features) inherent in the notion, the relevance of the substance to its attribute, the necessity of their correlation, the systematic approach to the notion - all this is primarily registered in the word and transformed by the word similarly to the human hand that transforms different mechanisms (Potebnja 1999: 145).

In this aspect, the internal form of the word and the notion look contagious. On the other hand, Potebnja emphasizes that the word may implement both the image (perceptive experience) and the notion. The role of the word here is paramount since the word is a means to elaborate the thought from the image into the notion; however, the word is considered as the void indicator of the latter:

The basic feature of the image implemented in the word does not render any meaning; rather, it serves as a sign or symbol of the known value; if during the formation of the notion the internal form of the word fades the way it happens with the majority of our root words, then the word become a void indicator of the thought, whereas no obvious relevance is observed between its sound form and meaning (Potebnja 1999: 147; emphasis added). 
This argument is significant since it points to the feature of Pierce's symbol: "a sign may represent its object by means of some conventional, habitual, dispositional, or lawlike relation, in which case it is called a symbol" (Lizska 1996: 39). Besides that, as Potebnja maintains, the internal form of the word does not implement the thought completely, but rather one of its features:

$<\ldots>$ the word does not render the whole idea but rather its one feature. $<\ldots>$ By the word window (Rus. okno) we usually understand some opening fitted with glass in a frame, whereas judging by its similarity with the word eye (Rus. oko), it stands for an opening where they look or where the light comes, however it does not suggest either frames etc. or the very notion of an opening (Potebnja 1999: 90).

This statement suggests the third feature of the internal form of the word. In modern terms, the diachronic process of nomination entails prominence (Langacker) in construing the semantic value of the word. According to Potebnja, the prominent feature(s) tend to concentrate in the word's etymological prototype.

Almost a century later, Potebnja's idea of word symbolism has been further elaborated as psycholinguistic theory of literature (Fizer 1986).

To conclude, Potebnia's tenet of the symbolism of language units departs from the nature of correlation between their internal and external form. Potebnja considers the comparative semantic value of the exclamation and the word by way of estimating their role in implementing the human thought or perceptive experience. He maintains that the exclamation is an onomatopoetic unit, since it is serves an indicator contiguous with certain perceptive experience. This nature of the exclamation is convergent with Pierce's definition of index. According to Potebnja's theory, word's internal form manifests three features that look significant for modern cognitive science. They are the following: firstly, word's internal form deals with a more or less completely formed idea of the object; secondly, it is viewed as a vehicle of the notion, and thirdly, viewed diachronically, it entails prominence in construing. The second feature indicates at the word as symbol in terms of Pierce's trichotomy.

\section{Conclusions}

Alexander Potebnja's scientific heritage encompasses ideas that nowadays underpin the whole array of state-of-the-art linguistic areas. In this article, I addressed three of his tenets that conceptually anticipated the basic postulates of evolutionary epistemology, cognitive and psycholinguistics, linguistic cultural studies and cognitive poetics. The first one, concerns language, thought and national spirit. In its terms, Potebnja, critically elaborated the ideas of his scientific mentor Humboldt and provided a comprehensive (for his time) account for language origin relevant to human cognition. Potebnja postulated that it plays a pivotal role in language evolution and human linguistic abilities. Besides, he considered language as a means of implementing perceptive experience of the human being viewed both in individual and national aspects. I consider these postulates as milestones in cognitive linguistics and the theory of the national construal of the world. The second Potebnja's tenet focuses on the evolution of mentality in terms of different types of world comprehension. He considers it as the correlation of image and meaning that evolve in myth, poetry and prose. In myth, as Potebnja maintains, image and meaning are axiomatically extrapolated, immanently for a naïve world perception. In poetry, image and meaning are contiguous but consciously distinguished. In prose, the relevance of these two elements is continuously challenged and is considered as only currently true. In this article, I read this tenet as one that conceptually anticipates Karl Popper's theory of Evolutionary Epistemology and Heinz Westman's theory of the ontogenesis of the psyche. The third Potebnia's tenet concerns the symbolism of language units. Accounting for the comparative semantic value of the exclamation and the word, he concentrates on the correlation of their external and internal forms. On his definition, the exclamation is an indicator of a perceptive experience, whereas the word is a vehicle 
of the notion. These features suggest the contiguity of the exclamation and the word with Pierce's index and symbol, correspondingly.

\section{REFERENCES}

Croft, W., Cruse, A.D. (2004). Cognitive Linguistics. Cambridge, New York, Melbourne, Madrid, Cape Town, Singapore, São Paulo: Cambridge University Press.

Evans, V. (2009) How Words Mean: Lexical Concepts, Cognitive Models, and Meaning Construction. Oxford: Oxford University Press.

Evolutionary Epistemology. Stanford Encyclopedia of Philosophy (SEP). Available at: https://plato.stanford.edu/entries/epistemology-evolutionary/

Fizer, J. (1986). Alexander A. Potebnja's Psycholinguistic Theory of Literature: A Metacritical Inquiry. Cambridge, Massachusetts: Harvard University Press. Available at: http://www.inmo.org.ua/assets/files/potebniana/Fizer.\%20Alexander\%20Potebnjas\%20Psycho linguistic\%20Theory\%20of\%20Literature\%20(1986)..pdf

Hunnings, G. (1988). The world and language in Wittgenstein's Philosophy. New York: State University of New York Press.

Kornilov, O.A. (2003). Jazykovye kartiny mira kak proizvodnye nacional'nyh mentalitetov [Language construals of the world as the derivatives of national mentalities]. Izdanie 2-e, ispravlennoe i dopolnennoe. Moscow: CheRo (in Russian).

Liszka, J.J. (1996). A General Introduction to the Semeiotic of Charles Sanders Peirce. Bloomigton and Indianapolis: Indiana University Press.

Munz, P. (2007). The Phenomenon of Consciousness from a Popperian Perspective. In: Consciousness Transitions Phylogenetic, Ontogenetic, and Physiological Aspects. Ed. by Hans Liljenström and Peter Århem. B.V. Elsevier. pp. 307-326.

Nikitin, M.V. (2007). Kurs lingvisticheskoj semantiki [The Course in Linguistic Semantics]. Uchebnoe posobie. 2-e izdanie, dopolnennoe i ispravlennoe. SPb.: Izd-vo RGPU im. A.I.Gercena (in Russian).

Popova, Z.D., Sternin, I.A. (2015). Jazyk $i$ nacional'nye kartiny mira [Language and national construals of the world]. Izd-nie 4-e stereotipnoe, Moskva-Berlin: Direct-Media (in Russian).

Popper, K. (1957/2002). The powerty of Historism. London and New York: Routledge Classics.

Potebnja, A.A. (1962). Obshhij literaturnyj jazyk i mestnye narechija [Common literary language and local dialects]. In: Oleksandr Opanasovich Potebnja. Kyiv. pp. 72-80 (in Ukrainian).

Potebnja, A.A. (1962). Lyst do A.O. Patery [A Letter to A. O. Patera]. In: Oleksandr Opanasovich Potebnja. Kyiv. pp. 93-95 (in Ukrainian).

Potebnja, A.A. (1989). Slovo i mif [Word and myth]. Moscow: Pravda (in Russian).

Potebnja, A.A. (1999/1892). Sobranie trudov. Mysl' i jazyk [Collected Works. Thought and Language]. Moscow: Labirint (in Russian).

Stepanov, Y.S. (2004). Koncept [Concept]. In: Konstanty: Slovar' russkoj kul'tury. $3^{\text {rd }}$ edition. Moscow: Akademicheskij proekt (in Russian).

Taylor, J.R. (1995). Introduction: On construing the world. In: Language and the Cognitive Construal of the World. Ed. by Taylor, John R. / MacLaury, Robert E. De Gruyter Mouton. pp. $1-22$.

Westman, H. (1983). Structure of Biblical Myths: The Ontogenesis of the Psyche. Spring Publications.

Wittgenstein, L. (2003 /1958). The Blue and Brown Books: Preliminary Studies for the 'Philosophical Investigation'. Oxford: Blackwell.

Ievgeniia V. Bondarenko - Professor, Professor of the Department of English Philology, Vasyl Karazin Kharkiv National University, 4, Maidan Svobody, room 7-78, Kharkiv, email: 
y.v.bondarenko@karazin.ua/ ORCID https://orcid.org/0000-0003-0654-1791, Google Scholar https://scholar.google.com/citations?hl=en\&authuser=2\&user=IPdzaq4AAAAJ

Свгенія Валеріївна Бондаренко - доктор філологічних наук, професор, професор кафедри англійської філології ХНУ імени В.Н. Каразіна. Майдан Свободы, 4, к. 7-78. м. Харків. Ел. адреса: y.v.bondarenko@karazin.ua/ ORCID https://orcid.org/0000-0003-0654-1791, Google Scholar https://scholar.google.com/citations?hl=en\&authuser=2\&user=IPdzaq4AAAAJ

Евгения Валериевна Бондаренко - доктор филологичсеких наук, профессор, профессор кафедры английской филологии ХНУ имени В.Н. Каразина. Площадь Свободы, 4, к. 7-78, Харьков. Эл. адрес: y.v.bondarenko@karazin.ua/ ORCID https://orcid.org/0000-0003-0654-1791, Google Scholar https://scholar.google.com/citations?hl=en\&authuser=2\&user=IPdzaq4AAAAJ 


\section{AMERICAN PLACE NAMES AS THE REFLECTION OF AMERICAN MENTALITY \\ L.G. Brutian (Yerevan, Armenia)}

L.G. Brutian. American place names as the reflection of American mentality. The paper is aimed at revealing the American mentality through toponyms. The object of the research are the names of towns and states of the USA with the exception of those of Indian origin. The following questions in the light of cognitive linguistics are analysed: carrying of the names from the native land, the repetitions of one and the same toponym, toponyms based on anthroponyms, toponyms based on common nouns, compound toponyms with atypical construction, abbreviations of place names, unofficial place names, etc. The analysis has revealed the following features of the American mentality: egocentrism of mind, individualism, leadership, superiority, imperial world-and-self-perception, enterprise, love for risk and challenge, independence, breaking of stereotypes, a positive view of the country, dynamism, mobility, devotion to law and truth, lack of hierarchy and official relations in communication, an informal style of interrelation.

Key words: abbreviation, American mentality, anthroponym, cognitive linguistics, extralinguistic, nickname, toponym.

Л.Г. Брутян. Американські топоніми як відображення американської ментальності. Метою статті $\epsilon$ виявлення американської ментальності через призму топонімів. Об'єктом дослідження $є$ назви міст і штатів США за винятком назв індіанського походження. Аналізуються такі питання в світлі когнітивної лінгвістики: перенесення імені з історичної батьківщини, повтори одного і того ж топоніма, топоніми, засновані на антропонімах, топоніми, засновані на номінальному іменнику, складові топоніми з нетиповою конструкцією, абревіатури топонімів, неофіційні назви міст і штатів і т.д. Аналіз виявив такі риси американської ментальності: егоцентризм, індивідуалізм, лідерство, перевага, імперське світо-ісамосприйняття, підприємливість, любов до ризику і викликів, незалежність, руйнування стереотипів, позитивний погляд на країну, динамізм, мобільність, законослухняність, прагнення до правди, відсутність ієрархічності та офіціозу в комунікації, неформальний стиль у взаєминах.

Ключові слова: абревіатура, американська ментальність, антропонім, екстралінгвальний, когнітивна лінгвістика, прізвисько, топонім.

Л.Г. Брутян. Американские топонимы как отражение американской ментальности. Целью статьи является выявление американской ментальности через призму топонимов. Объектом исследования являются названия городов и штатов США за исключением названий индейского происхождения. Анализируются следующие вопросы в свете когнитивной лингвистики: перенос имени с исторической родины, повторы одного и того же топонима, топонимы, основанные на антропонимах, топонимы, основанные на нарицательном имени существительном, составные топонимы с нетипичной конструкцией, аббревиатуры топонимов, неофициальные названия городов и штатов и т.д. Анализ выявил следующие черты американской ментальности: эгоцентризм, индивидуализм, лидерство, превосходство, имперское миро-и-самовосприятие, предприимчивость, любовь к риску и вызову, независимость, разрушение стереотипов, позитивный взгляд на страну, динамизм, мобильность, законопослушность, стремление к правде, отсутствие иерархичности и официоза в коммуникации, неформальный стиль во взаимоотношениях.

Ключевые слова: аббревиатура, американская ментальность, антропоним, когнитивная лингвистика, прозвище, топоним, экстралингвистический. 


\section{Introduction}

Toponyms, being the reflection of various sociocultural, historical, geographical and other factors, are, as it is known, an essential part of the word-stock of each language. Therefore, the necessity to study toponyms in relation to extralinguistic data - in sociolinguistic, ethnopsycholinguistic, culturological and cognitive aspects which shed light upon the mentality of their creators and bearers is beyond doubt. In this respect American toponyms because of their specific character and, in a certain sense, uniqueness as a result of various extralinguistic factors are of utmost interest for researchers. It is, indeed, hard to mention another country where such names of towns can be met as Paradise, Independence, Empire, Truth or Consequences, or a country where toponyms with the first component New are met so widely, or a country where London, Paris, Moscow and Rome are met simultaneously. The aim of the paper is to reveal the American mentality through toponyms. The object of the research are the names of towns and states of the USA with the exception of those of Indian origin. The material for the research was taken from Webster's New World College Dictionary [2016], Merriam-Webster's Geographical Dictionary [2007], New English-Russian Dictionary [1972], as well as Rand McNally Pocket Road Atlas [2006]. The methods of lexical, word-formative, lexico-semantic and statistical analysis have been used. The following particular questions in the context of cognitive linguistics will be analysed: carrying of the names from the native land; the numerous repetitions of one and the same toponym; toponyms based on anthroponyms; toponyms containing common nouns; the structure of toponyms, in particular, compound toponyms with atypical construction; abbreviations of toponyms, their slangish character; synonymous words and expressions denoting toponyms, their stylistic connotations, etc.

\section{Carrying of place names from the native land}

In the comment to Mark Twain's famous novel "The Adventures of Tom Sawyer" it is stated: "The Americans often give to their petty townships high-sounding names of capitals. They have several Parises, three or four Jerusalems, Constantinople and so on". This sentence can well serve as a key to understanding the mentality of Americans through their toponyms. Let us interpret this statement, singling out first the idea that "petty townships" are given "high-sounding names of capitals". It is worth mentioning first of all that the expression "petty townships" is used with great deal of irony, not to say sarcasm. It is common knowledge that emigrants who settle new lands endeavour to deaden to some extent their nostalgia by transferring geographical names from native land, thus as if recreating its image on a new land. At the same time, giving to their provincial town or a small settlement a name of a large capital sort of exalts their inhabitants, attaches past status and importance both to the new settlements and their inhabitants. And it doesn't matter that new Paris or new London are far from being world-famous Paris and London - the important thing is that the vanity of "New Americans" is being flattered. And, perhaps, inhabitant of American Paris deep in his heart thinks with satisfaction that he still lives in the "capital of the world". In connection with what has been said let us mention also such transferred names of large and famous cities (not only capitals), as, for example, Alexandria, Amsterdam, Athens, Berlin, Birmingham, Cairo, Florence, Geneva, Glasgow, Manchester, Melbourne, Milan, Moscow, Naples, Odessa, Oxford, Petersburg, Rome, Venice, Warsaw. The enumeration can be very long taking into account that "Americans often give ... names of capitals". By the way "the shabby township" described in "The Adventures of Tom Sawyer" is called after the then Russian capital, the magnificent city Saint Petersburg.

Among American toponyms transferred names of famous ancient cities are met as well, e.g. Palmyra - an ancient city in Syria. Moreover, there are great many small American towns named after a whole country, e.g. Albion (the poetic name of England), Angola, Brazil, Columbia, Holland, Lebanon, Mexico, Palestine, Peru, Russia. There are also names of towns which coincide with names of historic places, e.g. Arcadia - ancient province in Greece, Olimpia - region in Ancient Greece, etc. 
It is worth mentioning that among names of American towns there are such that are identical with names of American states. And what's more, these towns are not necessarily situated in the states called similarly. Examples: Nevada (MO), Virginia (MN). This fact, too, speaks about the exaltion of the own town by means of giving a name of a whole state. Also cases of identical names of small American towns and well-known islands, like, for example, Grenada, Trinidad, should be mentioned. Finally, there are great many toponyms with the word "new" preceding the name of a town from the historic land (New Bern, New London, New Madrid, New York) or the name of the historic land itself (New Albany, New Britain, New England, New Iberia). This group includes also names of towns containing adjectives denoting a country, e.g. French Lick, Spanish Fork.

\section{Toponyms based on anthroponyms}

It is known that in many languages a huge group of toponyms is based on anthroponyms, the analysis of which gives a vivid understanding of the importance and role of this or that proper name for the given culture. What concerns this group of American toponyms, it is rather heterogeneous, e.g. Lincoln - name of American President, Aurora - name of the goddess in Greek mythology, Bismarck - name of German chancellor, Bolivar - name of Venezuelan revolutionary, Euclid - name of ancient Greek mathematician, Hannibal - name of Karfagen general, Racine - name of the French writer, Shelley - name of the English poet, etc. This group of toponyms which contains names of famous historic and state figures, writers, mythological names, names of saints, etc. very often denotes settlements far from being large and significant. At the same time, it is important to stress that in the given group of toponyms often can be met place-names based on anthroponyms (male and female names and surnames) which do not speak for themselves at all or which are of local importance. A large number of such toponyms speaks to the fact that the American (new settler) himself comes to a decision what is important, what is of great significance for him. In other words, here is the manifestation of personal "self" which is in the base of American mentality; it represents the egocentrism of Americans' mind. As examples can serve Ada, Alma, Elmira, Marietta, Selma, etc. (female names), Frederick, Jerome, Pierre, Somerset, etc. (male names), Adams, Andrews, Clemson, Dawson, Harrison, Henderson, Jackson, Thompson, Jackman, Norman, Sherman, McAllen, McKeesport, McPherson, McRae, etc. (surnames belonging to different cultures). In the light of what has been said quite opposite are Russian and Armenian toponyms which contain anthroponyms of famous people only, though to different extent.

\section{Repetition of place names}

Let us, yet, go back to the analysed comment to Mark Twain's novel where it is mentioned that Americans "have several Parises, three or four Jerusalems... and so on". This is also a very important phrase for understanding the Americans' mentality. The reference is to the fact that one and the same name of a town is very often repeated twice or thrice or even more times in different states, and to avoid confusion the state is indicated after the name of a town. This is a unique case which has, in fact, no analogs in other cultures. Thus, for example, Aberdeen, Athens, Burlington, Cambridge, Clinton, Columbus, Freeport, Jackson, Lebanon, Middletown, Newton are met in four different states, toponyms Ashland, Columbia, Franklin, Newport, Washington are met in five states, six times in different states are used such place-names, as Greensville, Jacksonville, Springfield, and the toponym Salem "wanders" from a state to state for seven times. What is the reason of such a "nomadic life" of American toponyms? In our opinion, there are several reasons. Such repetitions can be explained, first of all, by the fact that the people living in the country or the new settlers have poor knowledge of the country, they limit themselves by the borders of their states and, as a rule, have no wish (as superfluous) to "poke their nose into another state" as a result of their quite prosperous life. There is another explanation which does not exclude the first one: the American lives as he wants (yet, strictly observing the law), his personal interests are above everything for him, he is an individualist and egocentric by nature, for him his country comes first of all to himself, 
to his house, his town. That is why he will use, if he wants, for the fourth or fifth or even sixth time the toponym with reference to his town or township: he doesn't care whether there might be such toponyms in other places - in any case his Franklin or Washington or Salem is the first among the towns having the same name because it is his town.

\section{Toponyms based on common nouns}

The names of North American towns include also a large group of toponyms based on common nouns. This group of toponyms, in its turn, consists of various names of flora and fauna, names connected with topographic division of land, names of town building objects, etc., which can be met in the toponymical layer of vocabulary of many other cultures as well. In the context of the given research we have focused on the place-names based on common nouns that reflect the specific mentality of the inhabitants of the country. Here are some examples: Alliance, Concord, Defiance, Faith, Hazard, Hope, Independence, Paradise, Globe, Empire, Enterprise. As can be easily seen, there is a reference to the typical features of American people and American way of life, such as risk, danger, hazard, challenge, enterprise, independence, faith, etc. There are also place-names with "imperial orientatedness", e.g. Empire, Globe, which testifies to "imperial" world - and selfperception of the Americans. In the light of what has been said of significance are also names of towns which contain words "love" and "sun", e.g. Loveland, Lovelock, Sun City, Sunbary, etc. These are toponyms which reflect the bright and positive view of the world and land settled by Americans.

Finally, the toponym Truth or Consequences should be singled out. It is, first, from the structural-semantic point of view, a curtailed text, a whole message, an implicit conditional warning or threat which can be explicated the following way: "Tell me the truth, otherwise you'll have the consequences" = "If you do not tell me the truth, you'll have the consequences". From the point of view of meaning the stress in the given toponym in laid on the word "truth" which denotes one of the most important concepts in the system of values of Americans - the concept opposite to that of falsehood, lie for which a person must undergo a punishment. The toponym under consideration is, no doubt, interesting also because of its extraordinary construction. While among American toponyms there are a lot of compound place-names (which is typical also for many other languages), the given toponym is remarkable for the inclusion of a conjunction. Moreover, even if it is possible to assume the inclusion in a toponym of the coordinate conjunction "and" (something like, for example, Forest and Mountains), the inclusion in the compound toponym of the conjunction "or" is a unique case, and it is hard to find the analog of this toponym in any other culture. Americans challenge in this as well, and in this they are leaders, in this case, too, they proceed from personal interests, breaking stereotypes and traditions. And these are features which, as has been already mentioned, are typical for their mentality. To prove the abovesaid, let us quote the following words by G. Tomakhin: "As one of the peculiar features of the toponyms of the USA many scholars indicate their being "extraordinary" and "picturesque". American place-names are, indeed, colourful and quaint, and this refers both to the form and meaning..." [Томахин 1982:45].

\section{Abbreviation of toponyms}

An extremely quick tempo of living (for Americans, indeed, "Time is money"), dynamism, mobility, quick and sharp change of events, the mosaic character of continuum (it is not by chance that the homeland of animated cartoon is the USA) - all this creates the world-image of Americans, their mentality and way of life and is manifested in such a widely-spread phenomenon as an intensive use of abbreviated forms of words and elliptical constructions in the American variant of the English language. Numerous abbreviations are met also among American toponyms. Both names of towns and states are being abbreviated. It should be mentioned that not only toponyms consisting of two parts are being abbreviated (New Orleans - NO, New York - NY, Los Angeles - LA, etc.) but also those consisting of one part (Boston - B., Philadelphia - Phila., Philly, etc.). Moreover, in some cases this or that toponym is being abbreviated minimally, that is, it is being shortened to one or two 
letters. For example, Boston - B., Washington - W., Florida - Fl., Ohio - O., Virginia - Va., etc. It is interesting that one and the same toponym can have two or even three variants of shortened forms. Examples: Cambridge - Cam., Camb; San Francisco - Frisco, SF; Washington - W., Wash.; California - Cal., Calif.; Kansas - Kan., Kans., Kas.; Nebraska-Na., Neb., Nebr.; North DakotaND., N. Dak.; Pennsylvania - Pa., Penn., Penna.; Vermont - Ver., Verm., Vt., etc. It should be mentioned that abbreviated forms are used also in case of toponyms which name several states (New England-N.E.; North-Western States - NWS) or all the states (United Stated of America - USA), as well as USA and Canada as a whole (North America - NA).

In conversational speech it is, of course, more convenient for the American to say instead of "I live in Los Angeles" "I live in LA", instead of "I love San Francisco" - "I love Frisco". It should be added, nevertheless, that these and other abbreviations have vivid slangish character. Compare: "The abbreviations of toponyms are often associated with slang and have the shade of familiarity, humour, low character" [Беленькая 1967: 140], “... when in San Francisco, one shouldn't say "Frisco". In native inhabitants' opinion, to use in conversation this nickname known to everybody means to be rude, vulgar, to have pretensions to familiarity with regard to something cherished" [Томахин 1982:104].

\section{Unofficial place names}

In this connection it should be stressed that typical for the American society informal, unofficial style of interrelation, the lack of hierarchy are reflected in the American variant of English (as opposite to British English) with its conversational, slangish and often humorous and ironic colouring. Compare: "There is no other country where it is possible to find so many place-names based on conversational expressions and slang as in USA" [Томахин 1982:45]. This, in its turn, is proved by the presence of various synonymous words and expressions denoting both towns and states. In addition, it should be mentioned that some toponyms have two and more synonyms (this fact, by the way, speaks about the free use of a toponym, about not being attached to one official place-name). Here are some examples: Big Apple (humorously), Fun City, Empire City, Gateway of the USA - New York; Quaker City, City of Brotherly Love (with humour or irony from the Greek "brotherly love") - Philadelphia; City of Magnificent Distances, Federal City - Washington, DC.; City of Monuments, City of Painted Window Screens - Baltimor; City of Notions, the Athens of America, Puritan City, the Hub, the Trimount (ain) City, etc. - Boston; City of the Golden Gate, Golden City, Queen City of the PacificSan Francisco (by the way, more than fifty variants of naming San Francisco are known [see Томахин 1982:121]; Windy City, Crossroads of the Continent - Chicago; City of the Angels, Roadsville (humorously) - Los Angeles. In connection with Roadsville, S. Vlakhov and S. Florin with reference to S. Kondrashov's book "A Visit to California" write: "In joke Los Angeles is called Roadsville". They add: "The author has elucidated questions of road construction in this city, describing the roads in detail, so the witty nickname as if summarizes the abovesaid" [Влахов, Флорин 2012: 219]. It is worth mentioning that witty Armenians have recently created another nickname for the city - Los Armenios, which speaks about the dominating influence of Armenians there. The enumeration of synonymous words and expressions denoting American towns can be long continued. As G. Tomakhin correctly mentions: "It is significant that the majority of expressively coloured variants is based on the term "city" (but not "town"), which deepens their meliorative orientation in accordance with the perception of the word "city"" [Томахин 1982: 122].

The unofficial city names (nicknames) of advertizing nature, characterize them as centres (italic is mine - L.B.) of the country's economic and cultural life" [Томахин 1982:122]. Examples: The Hub (humorously "the centre of civilization, culture") - Boston, the Empire City - New York, Capital of the West-Denver, Maple-Sugar Center, Capital of the World-St Johnsbury, VT, Rice Capital of the World - Crawly, LA, World's Leading Convention City, Crossroads of the ContinentChicago, City of Tomorrow - Oklahoma City. Here we come across the words "hub", "capital", "center", etc. It's worth mentioning that among these places with high-sounding names there are also 
small provincial towns. Besides, often are met expressions with the word "queen": Queen City Cincinnati, Queen City of the Lakes - Chicago and Buffalo, Queen City of the Plains - Denver, etc. Also such names can be mentioned, as Pride of the West - Cincinnati, Grand Dame of the Delta New Orleans. There are also parallel expressions with the word "most": Most Interesting City in the USA - New Orleans, America's Most Beautiful City - Savannah, Georgia and Talsa, Oklahoma (It is noteworthy that two different cities are named similarly).

Among parallel (variative) expressions transferred names of famous toponyms (denoting large cultural and industrial centres), both own and foreign, are met: Athens of America, Athens of the New World - Boston; Paris of America, Monmartre on the Mississippi - New Orleans; Chicago of the South - Houston, etc.

Of special interest are the following expressions of occasional character: Nineteen Suburbs Looking for a Town (in Search of a Metropolis), Life on a Horizontal without a Plan - both about Los Angeles. Of interest is also the parallel expression Believe It or Not Town (Eureka Springs).

The names of American states, of several states taken together, as well as the whole country also have unofficial variants (often more than one) pointing to the most typical features or the most important historic facts and events, sometimes - in an ironical form. Compare: "The specifity of American toponyms is in the wide use of both official and unofficial names of states (nicknames): in everyday discourse, in press, in fiction. Suffice it to refer to the fact that car number-plates have these striking and well known to every American names... Each state has several such nicknames and one of them (as a rule, of advertizing character) is used as an official one. This, quite a legalized nickname together with the slogan of the state, its flag, song, bird, animal and plant is mentioned in reference-books" [Томахин 1982:54-55]. Below are some examples: The Land of Stars and Stripes, The Land of the Bone-Dry Free (about the country during the period of prohibition), The New World - USA; The Land of Opportunity (the state of Arkansas); The Land of Steady Habits (the name of New England and State of Connecticut; New England is named also Town Meeting Country and Connecticut has the names The Arsenal of the Nation because of numerous weapon factories, The Blue Law State, The Nutmeg State); The Mother of Statesmen, The Mother of Presidents (seven out of the first twelve American Presidents came from State of Virginia), The Mother of States (the State of Virginia was the first which had been colonized), Down Where the South Begins (a high-flown nickname of the state which is the most southern state among Middle-Atlantic states); Boomer State (humorous name of Oklahoma); The Centennial State (the state of Colorado became a part of the USA in 1876 when the centennial of the USA Independence was celebrated; Dry State (about the state where alcoholic drinks were prohibited); The Hoosier State, The Crossroads of America (the official nickname of Indiana); The Empire State, The Excelsior State (from Latin "excelsior" meaning "higher and higher"; both denote the state of New York); The Evergreen State (ironical name of State of Washington which is situated in the far North-West of USA); Little Rhody (diminutive name of Rhode Island, the smallest American state); Wet State (a historic name of a state where it is allowed to sell alcoholic drinks); Show-me State (literally: "prove me state", "a distrustful state", "a state of sceptics" - about Missouri); The Treasure State (Montana); The Land of Enchantment (is given to New Mexico with its deserted scenery aiming to attract tourists); Uncle Sam's Handkerchief (a disdainful, ironic and witty nickname of Delaware which was given for its small sizes); Uncle Sam's Attic (disdainful nickname for Alaska which is perceived as the backyards of the country), Seward's Folly, Seward's Icebox (other disdainful nicknames for Alaska which was bought from Russia in 1867 on the initiative of State Secretary Seward); The Child of the Mississippi River (stylistically lofty nickname of Louisiana which is situated in the delta of the Mississippi river); The Hard-Case State (the nickname given to Oregon due to hard living conditions of the first settlers during the colonization of the state), The Beaver State (another nickname of Oregon which is associated with the role of fur-trade in the state; besides, for Americans beavers are associated with such features as inventiveness, quick wit and diligence); The Auto State (the nickname of Michigan due to the developed car industry in Detroit); The Land of Lincoln, The Sucker State (scornful 
nickname of Illinois the inhabitants of which became victims of machination of black marketeers during the colonization of the state); Baked Bean State (witty nickname of Massachusetts reminding of puritan days when baked beans were traditional Sunday meal).

Among nicknames of states having advertizing character there are such that contain names of other countries, e.g.: Switzerland of America (states of Maine, New Hampshire, New Jersey, West Virginia, Colorado, and again the same name is repeated from state to state); The Italy of America (Arizona); The Holland of America (Louisiana). Of interest are also such nicknames as, for example, The Sportsman's Paradise (Lousiana); The Wonderland of America (the name is given to Wyoming because of beautiful mountain landscapes); The Wonder State (by the decision of the Senate Arkansas was given this name in 1923 for advertising purposes. Just like the official nickname of the state - The Land of Opportunity it has aimed at covering up the unattractive picture of chronic unemployment and economic decline of one of the most backward states in US).

Of interest are also names of states based on their mottos, flags and coat-armours, e.g. Excelsior State (in the motto of New York State is the Latin word "excelsior" - the highest), North to the Future (the motto of Alaska), The Lone Star State (the official nickname of Texas, on the flag of which one star is depicted. Seized from Mexico by the slave-owners of the southern part of America, Texas was for some time an independent country, the economy of which was based on the hard work of slaves. Since that time on "the lone star" has symbolized the independent soul of Texas). In the given examples the key concepts are "highest", "future", "independence".

\section{Conclusion}

To sum up, the above-made analysis of toponyms in the cognitive linguistics context has revealed the following features of American mentality: egocentrism of mind, individualism (the dominance of "self", the preponderance of personal interests over social ones), leadership, superiority, imperial world-and-self-perception, enterprise, love for risk and challenge, independence, breaking of stereotypes and traditions, a positive view of the country, dynamism, mobility, devotion to law and truth, lack of hierarchy and official relations in communication, an informal style of interrelation. The research, thus, allows to come closer to understanding of the mentality of Americans through toponyms. Yet, a further and a more comprehensive analysis of the material under investigation in the suggested above aspect seems to be fruitful and perspective.

\section{REFERENCES}

Belenkaya, V.D. (1967). Nekotorije problemi mikrotoponimii anglogovorjashikh stran. [Some problems of microtoponymy of English-speaking countries]. In Mikrotoponimija [Microtoponymy]. Moscow: Moscow University Press (in Russian).

Merriam-Webster's Geographical Dictionary, $3^{\text {rd }}$ rev. ed. (2007). Ed. Merriam-Webster, N. MA: Merriam-Webster Inc.

New English-Russian Dictionary (1972).Ed. Galperin, I.R. Moscow: Soviet Encyclopedia Publishing House.

Rand McNally Pocket Road Atlas (2006). USA: Rand McNally \& Co.

Tomakhin, G.D. (1982). Amerika cherez amerikanizmi [America Through Americanisms]. Moscow: R. Valent Publishing House (in Russian).

Vlakhov, S. I. \& Florin, S. P. (2012). Neperevodimoje $v$ perevode [Untranslatable in the Translation]. Moscow: Higher School (in Russian).

Webster's New World College Dictionary, V ed. (2016). Editor-in-Chief Agnes, M.E. USA: John Wiley and Sons.

Brutian Lilit George - Doctor of Philology, Professor, Academician of Armenian Philosophical Academy, Head of Chair of Russian Linguistics, Typology and Theory of Communication, Yerevan State University; email: lilit.brutian@gmail.com, ORCID ID: https://orcid.org/0000-0002-2937-2663 
Брутян Ліліт Георгіївна - доктор філологічних наук, професор, академік Вірменської філософської академії, завідувач кафедри російського мовознавства, типології та теорії комунікації Єреванського державного університету; email: lilit.brutian@gmail.com, ORCID ID: https://orcid.org/0000-0002-2937-2663

Брутян Лилит Георгиевна - доктор филологических наук, профессор, академик Армянской философской академии, заведующая кафедрой русского языкознания, типологии и теории коммуникации Ереванского государственного университета; email: lilit.brutian@gmail.com, ORCID ID: https://orcid.org/0000-0002-2937-2663 


\section{LINGUOPOETICS OF CORPORALITY IN LITERARY TEXTS OF ENGLISH MODERNISM AND POSTMODERISM Iryna Galutskikh (Zaporizhzhya, Ukraine)}

I.A. Galutskikh. Linguopoetics of corporality in literary texts of English modernism and postmoderism. The article focuses on the study of linguistic manifestations of corporality in literary texts of English modernism and postmodernism, which envisages the analysis of literary corporality as a linguopoetic category. As a product of cognition and literary conceptualization of human bodily experience in the dialectic unity of its somatic-physiological, sensory, psychic, and mental facets, this category is formed in compliance with the author's aesthetic purport in the context of an epoch, being manifested in literary text through its verbal, imagistic, and narrative semiotic means. Given the assumption that a literary text is a multilevel verbal unity, comprising a complicated system of codes, the research applies a cognitive-semiotic approach to the analysis of literary corporality. Such an approach fostered revealing the specificity of multidimensional textual representation of literary corporality, including a fictionalized body as a narrative construal, with regard to a set of mental structures relevant to literary interpretation of corporality. The authorial construal of fictionalized body incorporates three dimensions: conceptual, narrative-semiotic, and verbal. This construal is represented in the narrative by its three varieties: sensory-emotional, eroticized, and socialized bodies. They are marked by narrative patterns which specify linguopoetic features of corporality in literary texts of English modernism and postmodernism, related to its conceptual, narrative-semiotic, and verbal manifestations.

Keywords: cognitive poetics, cognitive semiotics, construal, constructing, linguopoetics, linguopoetic category, modernism, fictionalized body, postmodernism, literary text, literary corporality.

І.А. Галуцьких. Лінгвопоетика тілесності в художніх текстах англійського модернізму та постмодернізму. Стаття присвячена вивченню мовних проявів тілесності в художніх текстах англійського модернізму та постмодернізму, що передбачає аналіз художньої тілесності як лінгвопоетичної категорії. Як продукт пізнання та літературної концептуалізації людського тілесного досвіду в діалектичній єдності його соматико-фізіологічного, сенсорного, психічного і ментального аспектів, ця категорія формується відповідно до естетично спрямованої діяльності автора в контексті епохи, яка проявляється в літературному тексті через його словесні, образні та наративно-семіотичні засоби. 3 огляду на розуміння художнього тексту як багаторівневого вербального утворення, що охоплює складну систему кодів, дослідження застосовує когнітивно-семіотичний підхід до аналізу художньої телесності. Такий підхід сприяв виявленню зв'язків багатовимірного текстового подання художньої тілесності, включаючи охудожнене тіло як наративний конструкт, із комплексом ментальних структур, пов'язаних 3 художнім відображенням тілесності. Авторське конструювання охудожненого тіла включає три виміри: концептуальний, наративно-семіотичний та словесний. Цей конструкт представлений в наративі трьома різновидами: сенсорно-емоційним, еротизованим та соціалізованим тілом. Вони марковані наративними моделями, які специфікують лінгвопоетичні особливості тілесності в художніх текстах англійського модернізму та постмодернізму, пов'язані 3 його концептуальними, наративно-семіотичними та словесними проявами.

Ключові слова: когнітивна поетика, когнітивна семіотика, конструкт, конструювання, лінгвопоетика, лінгвопоетологічна категорія, модернізм, охудожнене тіло, постмодернізм, художній текст, художня тілесність.

И.А. Галуцких. Лингвопоетика телесности в художественных текстах английского модернизма и постмодернизма. Статья посвящена изучению языковых проявлений телесности в

(C) Galutskikh I.A., 2018 
художественных текстах английского модернизма и постмодернизма, что предусматривает анализ художественной телесности как лингвопоэтической категории. Как продукт познания и художественной концептуализации человеческого телесного опыта в диалектическом единстве его соматико-физиологического, сенсорного, психического и ментального аспектов, эта категория формируется в соответствии с эстетически направленной деятельностью автора в контексте эпохи, что проявляется в художественном тексте через его словесные, образные и нарративно-семиотические средства. Учитывая понимание художественного текста как многоуровневого вербального образования, охватывающего сложную систему кодов, в исследовании применяется когнитивносемиотический подход к анализу художественной телесности. Такой подход способствовал выявлению связей многомерного текстового представления художественной телесности, включая охудожествленного тела как нарративный конструкт, с комплексом ментальных структур, связанных с художественным отображением телесности. Авторское конструирование охудожествленного тела включает три измерения: концептуальное, нарративно-семиотическое и словесное. Этот конструкт представлен в нарративе тремя разновидностями: сенсорно-эмоциональным, эротизированным и социализированным телом. Они маркированы нарративными моделями, которые специфицируют лингвопоэтологические особенности телесности в художественных текстах английского модернизма и постмодернизма, связанные с его концептуальными, нарративно-семиотическими и словесными проявлениями.

Ключевые слова: когнитивная поэтика, когнитивная семиотика, конструкт, конструирование, лингвопоэтика, лингвопоэтологическая категория, модернизм, охудожествленное тело, постмодернизм, художественный текст, художественная телесность.

\section{Introduction}

The meaning of corporality in the humanities has always been complicated since the term has been applied in multidisciplinary context. This caused ambiguity and stipulated a wide range of its interpretations. The latter fall into three groups based on:

1) philosophic interpretation of corporality where the term "corporality" is defined within ontological approach as substantial, special and temporal being of body (Frolova 2000; Krutkin 1997; Ostry 2007), phenomenological approach (where corporality is treated as somato-physiological and psycho-emotional entity) (Merleau-Ponti 1999; Podoroga 1995) and epistemological approach as interrelation of physiological and mental aspects of being (Kniazeva 2009);

2) sociocultural understanding of corporality as body being transformed under the influence of sociocultural factors (Bykhovskaya 2000; Korietskaya 2006) that comprises semiotic vision of corporality as a code system (Verbytska 2009);

3) philological interpretation with linguistic (Korotun 2002; Materynska 2009; Seryakova 2012; Zalevska 2005), literary (Gundorova 2010; Khrabrova 2001; Kulichikhina 2012; Poltarobatko 2009) and linguopoetic (Nasalevich 2003; Skachkov 2007) approaches, including interdisciplinary branches - cognitive linguistic (Klievtsova 2007; Marmaridou 2011; Stetsiura 2010), cognitive poetic (Ibarretxe-Antunano 2002; Kövecses 2002), cognitive semiotic ones (Violi 2010; Ziemke 2003; Zlatev 2008).

Linguistic studies of corporality manifested in language and text by nominations of human body and bodily experience have traditionally been limited to the analysis of somatic lexicon as a system formation (Alieva 2010; Zamoiska 2004) having communicative (Soloschuk 2006), cultural (Gudkov, Kovshova 2007), semiotic (Arkadiev, Kreidlin et al. 2008; Gudkov, Kovshova 2007; Sieriakova 2012) and conceptual significance as experiential basis for the processes of conceptualization and categorization (Gallagher 2006; Lakoff \& Johnson 1980; Ziemke 2003; Zlatev 2008). Literary studies have focused on the aspects of corporality actualized in literary texts of different genres and epochs being pronouncedly accentuated in modernism and postmodernism literature (Poltarobatko 2009; Shteinbuk 2006; Shtokhman 2008). Linguopoetic research of corporality comprises the analysis of somatic vocabulary connotative meaning (Yeliferova 2007), sensory concepts (Bogumil 1988; Mescheriakova 2011; Pierminova 2003; Starostina 2009; Vorobyova 
2012) and their role in the imagery formation of literary texts, stylistic aspects of characterisation (Nasalevich 2003; Skachkov 2007; Tataru 2007).

The integration of all approaches to corporality suggested in the discourse of the humanities enabled its complex interpretation as a category and became the basis for its understanding as a linguopoetic category.

The core of the category is the concept of human body which acquires under the impact of sociocultural factors a series of properties in addition to initial ones, thus, set of properties of the category "corporality" comprises two groups of parameters: 1) ontological as basic ones manifested in somato-physiological, sensory, psycho-emotional and mental characteristics, and 2) sociocultural ones, among them being semiotic nature implying gender, eroticized and transformation qualities.

The abovementioned interpretation of corporality as an ontological and sociocultural category envisages the understanding of literary corporality as a linguopoetic category being the object of this research in its verbal and narrative dimensions in literary texts of English modernism and postmodernism.

The research proceeds from interpreting this category in combination of its logical and philosophical understanding as a denotative and referential phenomenon that in literary text functions as an entity having content and expression sides (Turayeva 1979), as well as of its cognitive and semantic interpretation resultant from the process of categorization (Rosch 1980).

Literary corporality as a linguopoetic category is a product of cognition and literary conceptualization of human bodily experience in the dialectic unity of its somatic-physiological, sensory, spiritual (psychic), and mental aspects. This category is formed in compliance with the author's aesthetic intention in the context of a certain epoch, being actualized in literary text with the help of verbal and narrative-semiotic means.

The subject of my research is linguopoetics of corporality as a set of dominant lingual properties of a literary text employed by an author for realization of an artistic idea in view of vision of corporality specific for author's style and literary trend.

Given the assumption that a literary text is a multi-level verbal formation comprising a complicated system of codes (Barthes 1989), the research applies a cognitive-semiotic approach to the analysis of literary corporality as a linguopoetic category, using as the empirical material a corpus of English modernism (V. Woolf, D.H. Lawrence) and postmodernism (J. Fowles, P. Ackroyd, J. Winterson, I. Vaugh, S. Rushdie, F. Weldon, A. Burgess) literary texts.

This approach fostered reaching the aim of this research - revealing the specificity of multidimensional textual representation of literary corporality with regard to the verbal and narrativesemiotic dimensions of fictionalized body as a construal. It also allowed to discover interconnections of literary text semiotic structures and mental structures, relevant to literary interpretation of corporality.

\section{Method}

A cognitive-semiotic approach to the analysis of literary corporality in English modernism and postmodernism applied in this research comprises three stages of the procedure.

The first stage of analysis implies identification of the inventory of textual signals by means of their selection from lexicographic sources, systematization and description of language means of English nominating Homo somaticos, integrating its somatic, physiological, sensory, psychicemotional and mental aspects.

Key verbal markers of corporality in English are the following lexical means:

- corporality (corporeality, corporeity), embodiment and carnality as well as constituents of its synonymic group: fleshliness, sensitivity, sensitiveness, sensuality, sexuality, libido, lustfulness, voluptuousness, lechery, prurience (CCT 1997);

- body as the most generic term with the highest index of frequency (327 according to DFEL as well as constituents of its synonymic group: build, figure, flesh, form, frame, physique, shape, 
torso, trunk, cadaver, carcass, corpse, deadbody, relics, remains, stiff (CCT 1997) and their derivatives: bodiless, bodies, bodily, embody, embodiment, body (v), body-built, body-line, bodycentered, bodyguard, bodywork, bodycavity, bodyfluid, bodycell, bodycheck, bodyclothes, bodyheat, bodyimage (WTNIDEL 1993) etc., with the semes 'pertinent / characteristic of the body, 'similar to the body';

- structural and semantic derivatives of the constituents of synonymic groups of the abovementioned lexical means with the semes 'somato-physiological': anatomical, bodily, carnal, corporal, corporeal, fleshly, physical, somatic (CCT 1997); 'sensory: sensory, sensitive, sensorimotor, perceptive (CCT 1997), 'carnal, sensual, sexual': carnal, fleshly, erotic, erogenous, lecherous, lascivious, lewd, libidinous, lustful, prurient, licentious, sensual, sensuous, sexual, voluptuous, sensory (CCT 1997);

- verbs nominating the process of embodiment: embody, incarnate, incorporate, corporealize, carnalize, carnify (CCT 1997).

Selected linguistic (lexical, phrasal, syntactic, etc.) signals of corporality in literary texts of English modernism and postmodernism are taxonomized in accordance with various criteria:

1) according to the type of their thematic reference to the following semantic groups:

- "Somatics and physiology", that falls into:

- "Homo somaticos (external)" including "Parts of body" (head, neck, trunk, thorax, chest, breast, abdomen, dorsum, back, pelvis, arms, hands, fingers, legs, feet, toes, buttocks, thighs, elbows, shins, heels, wrists), "Face and its parts" (face, nose, forehead, eyes, eyebrows, lips, tongue, beard, chin, cheek, eyelid, eye-lashes), "Foramen" (nostrils, mouth, cavity, eyesocket, auricle, anus), "Body lines and heterogeneous somatic objects" (waist, loins, wrinkles, scar, dimples, acne, freckles, armpits, mole, birthmark, rash);

- "Homo somaticos (internal structure and functioning)" including "Organs and their systems" (organs, entrails, viscera, heart, blood vessels, veins, capillaries, arteries, aorta, blood circulation, digestive system, glands, stomach, intestine, liver, gastrointestinal tract, pharynx, spleen, pancreas, gallbladder, appendix), "Cellular structure of the body" (gene, mitosis, neurons, DNA, cell, erythrocytes, lymphocytes, leukocytes), "Physiological liquids and substances" (blood, plasma, lymph, phlegm, mucus, bile, sweat, tears, urine, saliva, semen, gastric juice, breast milk, hormone, adrenaline, amino), "Physiological states and processes" - normative (metabolism, homeostasis, peristalsis, perspiration, secretion, sleep, hunger, thirst, breathing, digestion, pregnancy, ovulation) and pathological (disease, immunodeficiency, pathology, illness, lethargy, agony, swelling, indigestion, insomnia, inflammation, tumour, metastasis, cancer, flu, pneumonia, fever, pain, bruise), "Physiologic ontogenesis stages" (embryo, foetus, puberty, baby, oldness, old age, life, death);

- "External body qualities and body behaviour" characterising such parameters of the body as "size", "weight" (corpulence, fatness, obesity, tall, slim), age (young, old), nation and race (Europeoid, coloured, Roman nose), aesthetic features (tanned, pale, complexion, handsome), gender qualities (manlike, masculine, female, womanly, feminine, sex), "bodily" actions (smile, frown, kiss, mimics, gesture);

- "Sensory and organs of perception" (touch, palpate, vision, olfaction, hearing, taste);

2) according to quantitative distribution - singular (eye), dual (organ of vision, organ of sight) and multiple - groups of signals;

3) according to the type of nomination - denotative (head) and connotative (e.g. colloquial equivalents of head-dome, top, melon, nut, skull, bean, etc. meaning "head");

4) according to the textual scope - global, local and localized found out and interacting within the whole text, its fragment or separate component (Vorobyova 1993).

Selected linguistic signals serve for identification of text fragments in which literary corporality is actualized as well as in the course of reconstruction of conceptual tropes and narrative patterns. 
The second stage of research is the analysis of its imagery and symbolic aspects by means of reconstruction of conceptual tropes which demonstrate the way the image embodies vision of human body and bodily experience in verbal form.

The stages of reconstruction of conceptual tropes on the text fragment of P. Ackroyd's "London: The Biography": Here might be found the 'heart of London' beating warm. The byways of the city resemble thin veins and its parks are like lungs (Ackroyd LB, p. 2-3) are the following:

1) identification of verbal imagery means including corporality nominations (heart, lungs) and selection of corresponding text fragments;

2) identification of the type of interrelation (comparing, contrasting, etc.) between contiguous objects, where by means of conjunctions like (its parks are like lungs), as (London as a human body), as if (stones and cobbles [...] look as if they are bleeding), as well as lexical unit resemble (byways of the city resemble thin veins), iconic principle of distance comes into work due to maximum proximity of constituents (Dirven \& Verspoor 2004);

3) definition of source and target domains of imagery conceptualization - something that is described (CITY) and the means used to describe it (HUMAN BODY), with the help of their verbal nominations (London, byways, parks and veins, heart, heart);

4) elaboration of typology of imagery of corporality in accordance with the type of cognitive operation beneath: analogy (byways resemble veins, parks like lungs), association (her fear made her heart beat increase), contrast (bitter sweetness, pleasure close to pain, frozen cheek burned me), specification / characterisation (R. Langacker 1990) (ruined body, deformed body), etc.;

5) systematisation of the results obtained by means of stating the range (one referent - several correlates) and scope (one correlate - several referents) of conceptual metaphors (Kövecses 2002);

6) quantitative analysis for revealing the imagery priorities of a text, cognitive style of a writer, literary trend - modernism or postmodernism in view of the vision of corporality.

The third stage of the analysis of literary corporality is reconstruction of its narrative aspect, i.e. specific features of body experience narration in a literary text with the help of narrative patterns - schemes of narration of human body or its properties.

The algorithm of the analysis comprised the following steps:

1) identification of narrative signals of verbal and/or adjectival type that respectively designate body actions or events (kiss breast, body melts, body burns, touch skin, smell sweet, feel agony), or nominate properties or conditions of a body (wounded in the arm, naked body, dissolved body, pierced heart, broken heart);

2) classification of narrative signals in accordance with their semantics and elaboration of typology of fictionalized body in literary texts of English modernism and postmodernism. Its types embrace sensory-emotional body (taste sweet, feel pain, suffer headache, tremble with cold, frozen blood), eroticized body (lie naked, lick lips, kiss breast, entity of bodies) and socialized body (bodies communicate, well-trained body, stigma burnt on flesh, people without faces, skeleton of social habit);

3) singling out narrative patterns - schemes of narration of two main types - designating the vector of corporality transformations (e.g. "eroticizing", "socializing", "psychologizing", with oppositions "natural" vs "unnatural" within each of them, and type of corporality transformations characterising body changes in literary semantics according to their intensity: "modification", "deviation", "deformation", "destruction";

4) systematisation of the results obtained and quantitative analysis for revealing the imagery priorities of a text, cognitive style of a writer, literary trend (modernism or postmodernism) in view of the vision of corporality.

The narrative code constituents that embrace compositional and narrative signals of literary corporality, which form respective narrative patterns, contribute to the manifestation of fictionalized body as a narrative construal. 


\section{Results and Discussion}

In terms of cognitive-semiotic approach, literary corporality is viewed as multi-level formation integrating linguistic (represented by verbal and narrative codes) and cognitive structures. Interrelation of two types of codes in a literary text is based on the following factors: 1) verbal code constituents serve as denotative and connotative means of corporality nomination; 2) narrative codes of literary corporality contribute to its narrative embodiment in a succession of actions and events of the body within a single temporal and spatial image or plot of a literary text creating the vision of corporality.

Linguistic aspects of literary corporality in entity of verbal and narrative codes correlate with its cognitive dimension forming entire cognitive-semiotic space of literary corporality.

The research introduces a cognitive-semiotic interpretation of literary corporality as a model which reveals the correlation of its cognitive dimension comprising the prototypic vision of corporality as a material phenomenon and semiotic dimension related to verbal and discursive as well as narrative manifestations of corporality in a literary text as a multi-layered semiotic system.

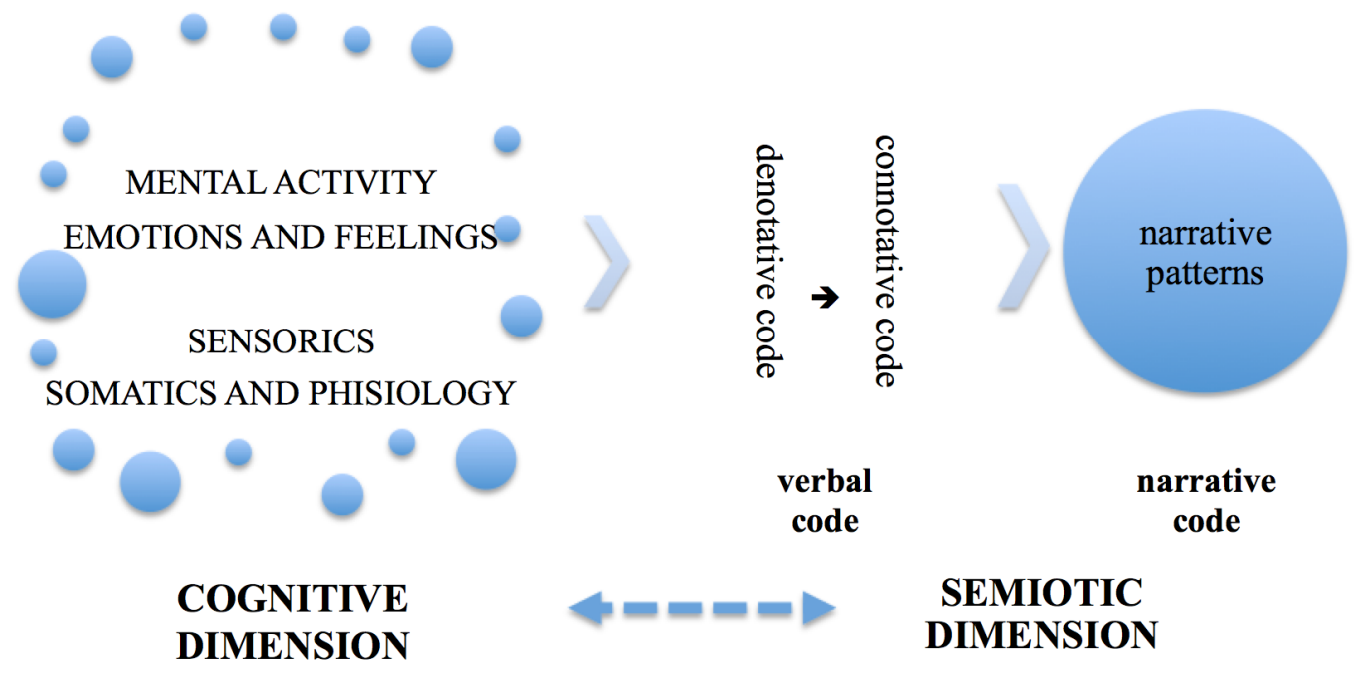

Figure 1 . The model of literary corporality as a linguopoetic category

The cognitive dimension of literary corporality as a category comprises the conception of human body and bodily experience in the dialectic unity of their somato-physiological, sensory, psycho-emotional, and mental facets as its ontological background, while integrating four interrelated thematic domains SOMATICS AND PHYSIOLOGY, SENSORY PERCEPTION, EMOTIONS AND FEELINGS, MENTAL ACTIVITY.

The semiotic dimension of literary corporality in its verbal and narrative planes embraces a multitude of multilevel linguistic means as well as compositional and narrative devices that are employed as textual signals of this category.

According to the type of nomination the constituents of verbal code of literary corporality fall into denotative and connotative. The first group includes nominations of somato-physiological aspects of human body as a referent (She registered the warm tones of the two female figures [...] level-eyed and barefooted (Fowles ET: 3 ). The latter includes imagery means of literary corporality where human body becomes target domain - I would call her nipples twin domes of her body's temple (Lodge T: 178) or source domain of conceptualization - the house resembled the torso of a man rearing up, while his arms still lay spread [...] it was as if I were about to enter a human body (Ackroyd HDD: 3). The second group includes textual symbols as well (My nose: elephantine as the trunk of Ganesh, have been a superlative breather; a smeller without an answer (Rushdie MC: 31), Doctor Aziz's nose - comparable only to the trunk of the elephant-headed god Ganesh- 
established incontrovertibly his right to be a patriarch (ibid: 9) and symbolized imagery (Twisted shells with red lips ornamented the mantelpiece (Woolf VO: 9).

The narrative level of literary corporality comprises narrative means that form narrative code realized by narrative patterns. Systematization of narrative patterns recurrent in literary text enabled the identification of narrative varieties of fictionalized body. Their reconstruction revealed specific features of literary corporality as a linguopoetic category in its narrative-semiotic manifestations in English literary texts of modernism and postmodernism in their juxtaposition.

A fictionalized body is interpreted as a narrative construal that incorporates cognitive, narrativesemiotic, and verbal levels, while being represented in the narrative by its three varieties: sensoryemotional, eroticized and socialized bodies.

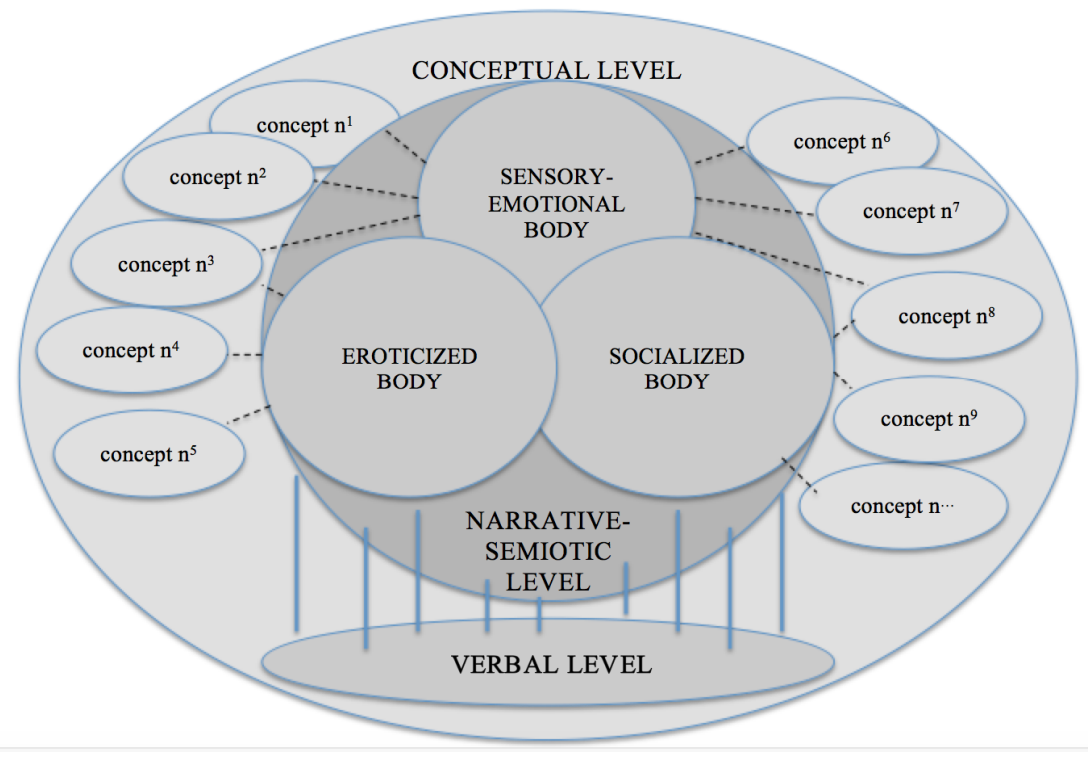

Figure 2. Fictionalized body as a construal

Their construction by the author involves such narrative patterns as "psychologizing / pathologizing", "eroticizing", or "socializing", respectively. Each above-mentioned narrative variety of fictionalized body finds its manifestation through the corporality transformations ranging according to the scale of "modification" - "deviation" - "deformation" - "destruction", which occur in the narrative structure of literary text in its referential, imagistic and/or symbolic planes. The vector and type of fictionalized body transformations specify the features of linguopoetics of corporality in the analysed texts of English modernism and postmodernism, thus characterizing the modernist and postmodernist visions of corporality manifested in them both in cognitive and verbal facets, thus shaping the narrative varieties of fictionalized body.

Specific features of sensory-emotional body construction consist in the narrative "deformation" of fictionalized body and its reconceptualization according to the model SENSORY-EMOTIONAL BODY IS A DEFORMED BODY in the English modernism prose, whereas in the literary texts of English postmodernism its narrative "destruction" according to the conceptual model SENSORY-EMOTIONAL BODY IS A RUINED BODY is observed. Narrativisation of the fictionalized body takes place against the background of its "psychologizing" in the English modernistic texts under study and "psychologizing / pathologizing" - in the literary texts of English postmodernism.

Narrative pattern "psychologizing" implies imagery conceptualization of corporeal phenomena as emotional and psychic states of a human: A great pang of fear went through his heart (Lawrence EME: 17), where conceptual metonymy SHARP PAIN IN THE HEART stands for FEAR is accompanied with the metaphor SHARP PAIN IS PIERCING, and This hole in my heart is in the shape of you and no-one else can fit it (Winterson WB: 155), where conceptual metaphor 
PSYCHOLOGICAL LOSS IS A HOLE IN ONE'S HEART, based on conventional conceptual metonymy HEART stands for EMOTIONAL STATE OF A PERSON, in its verbal facet serves as a textual reference to the lost love and suffering.

Textual signals of human body imagery conceptualization in literary verbalisation of emotions and feelings are lexical units body, flesh, parts of body, organs and physiological liquids (heart, blood, breast, bosom, bowels, bones, womb, throat, head), physiological processes and phenomena (bleeding, lethargy, agony, intoxication, bruise, pain, death, suffocation, spasm, body paralysis, soberness), sensory of the body (senselessness, torment, taste, physical pain, heat in the body), corporeal states (body shuddering, trembling body, body tension), physical qualities of the body as weight, size (heavy body, light body, small body), bodily actions and body position in space (swallowing, embracing, queer movements).

Such means of verbalisation sustain the idea of close integration of conceptual spaces of corporeal, psycho-emotional and mental experiences of a human being. Merging of domains HUMAN BODY and EMOTIONS / FEELINGS observed in literary texts of English postmodernism is accompanied by semiotization on the narrative level implying imagery conceptualization of HUMAN BODY as A SIGN: I took her two hands to my mouth and kissed each slowly so that I could memorize the shape of her knuckles (Winterson WB: 50), where tactile contact is viewed as perception of information (TOUCH stands for MEMORIZING).

Narrative pattern "pathologizing", specific of literary corporality of English postmodernism, implies reference to pathologies of the body and serves for verbalisation and narrativisation of ill body:

Cancer treatment is brutal and toxic. Her spleen started to enlarge, she had splenic irradiation or even a splenectomy, she would be badly anaemic, bruising and bleeding, in pain, constipated, vomiting and nauseous, it would contribute to failure of her bone marrow. There is no cure for lymphocytic leukaemia (Winterson WB: 102).

The role of textual signals of pathological (ill) body in this text fragment is played by nominations of illness (cancer, lymphocytic leukaemia) and of bodily pathological states as its consequences (spleen enlarging, splenic irradiation, splenectomy, anaemic, bruising, bleeding, in pain, constipated, vomiting, nauseous, failure of bone marrow).

In J. Winterson's novel "Written on the Body", ill body becomes target domain of imagery conceptualisation as well, e.g. CANCER is metaphorically described as BETRAYAL OF THE BODY, while THE BODY HAVING CANCER - as THE BODY THAT BETRAYED ITSELF: Cancer is an unpredictable condition. It is the body turning upon itself (Winterson WB: 105), or as a VICTIM OF INTERNAL REBELLION: but the white T-cells have turned bandit. They don't obey the rules. They are the enemies on the inside. The security forces have rebelled (ibid: 115), where defending forces of the organism itself become the members of the coup depicted on the background of corresponding physiological processes.

Realization of narrative patterns "psychologizing" and "pathologizing" of the body in literary texts of English modernism and postmodernism corresponds to certain types of transformations of corporality accompanied by actualisation of narrative patterns "deformation" and "destruction".

In literary texts of English modernism psychologising of fictionalized body is accompanied with its "deformation" and conceptualisation according to the model of characterisation SENSORYEMOTIONAL BODY IS A DEFORMED BODY. On the level of verbal code it is described as an object having lost its integrity, consistence, size, etc. and, eventually, experiencing pain (e.g. melting body, physical wreckage, rigid body, shrunk body, heavy body, bleeding heart, lethargy, spasm, agony, body paralysis) or having potential of possible deformation that is implied by means of placing the character in the situation concerned with it (e.g. heat / coldness in the body, halt of heart, the rise of blood pressure, suffocation, intoxication). 
The narrative pattern "deformation" is actualized in fragments of literary modernistic texts, where imagery transformations concern:

- body as a whole (32\%), usually by means of narrativisation of conceptual metonymies:

- RIGID BODY stands for INDIFFERENCE: over them both came paralyzing blankness of feeling [...] as the mind turns rigid, so does the body; stark, statuesque (Woolf TA: 143),

- SHRUNK BODY stands for UNCERTAINTY: She felt as if her body had shrunk; it had grown small (Woolf LL: 71);

- parts of body (27\%) as, e.g. in metaphtonymies with heart as a component: Our hearts melted away, we thought to die (Lawrence FSG: 89), where the metaphor HEART IS A MELTING SUBSTANCE becomes a correlate for FEAR, and When Egbert saw his little girl limping, his heart again hardened with chagrin, like steel that is tempered (Lawrence EME: 20), where the metaphor HEART IS A HARDENED SUBSTANCE stands for GRIEF;

- physiological liquids that metaphorically undergo chemical changes (13\%): The officer sat [...] all his blood seemed to be corroding (Lawrence PO: 6), where CORRODED BLOOD stands for FEAR.

The construction of sensory-emotional fictionalized body by means of its psychologising in literary texts of English postmodernism is accompanied by its "destruction" according to the conceptual model of characterisation SENSORY-EMOTIONAL BODY IS A RUINED BODY. Among textual signals of this type the word body and constituents of its synonymic group - flesh, physique are the most frequent. In $87 \%$ of text fragments of postmodernist literary prose we observe metaphoric images of "ruined body" with violated structure, consistency or integrity (e.g. softened body, weakened body, ill body, dead body, enlarged body, wounded body, bleeding body). Noticeably, predominantly (in $77 \%$ of text fragments) they are the imagery correlates of positive feelings, e.g. in the course of imagery conceptualization of high body temperature as body in passion: We made love [...] those brief hours were offerings to a god who would not be appeased by burning flesh (Winterson WB: 20), When ever you think you are falling in love, remember that ring is molten hot and will burn you through and through (ibid: 31-32). The verbal markers of conceptual metaphtonymy BODY IS A BURNING FIRE stands for PASSION, DESIRE are burning flesh or the phrase will burn you through and through that explicitly or implicitly emphasize destructive influence of emotional state on the body.

Allusions as signs of intertextuality are specific features of literary texts of English postmodernism observed in the imagery interpretation of body in passion:

"...the steady flame she offered might be fed ... if Louise were a volcano then I might be Pompeii (Winterson WB: 49).

Metaphorical interpretation touches the bodies of both lovers: one is conceptualized by means of associating image-metaphor BODY-FIRE with metaphorical correlate VOLCANO, the other - by means of comparing image-metaphor BODY IN FIRE to POMPEII. This image is based on metaphor of parabolic type (Turner 1998), where narrative mapping is applied - the projection of the famous historical event story (ruining of Old Roman city of Pompeii that was burnt during Vesuvius eruption in 79 AD) on the meaning of the literary image (Bieliekhova 2002).

Cognitive processes involved into image formation in the course of sensory-emotional body construction are common for modernistic and postmodernistic literary texts and embrace analogous $-a$ metaphor (BODY IS POMPEII), associative - a metonymy (HIGH RATE OF HEART BEAT stands for FEAR), as well as metaphtonymic means as their combination (RIGID BODY stands for INDIFFERENCE).

Narrative patterns actualized in analysed texts envisage the typology of sensory-emotional fictionalized body which is depicted in modernistic prose as unnatural, psychologized, semiotic and deformed whereas in postmodernistic - as unnatural, psychologized, semiotic, destructed and pathologized. 
The quantitative analysis demonstrated more pronounced significance of sensory aspects of the body - tactile, visual, gustatory, olfactory and audial, $87 \%$ of spectre being associated with unpleasant and painful emotional experience of literary characters.

Literary texts of English modernism tend to construct eroticized fictionalized body by means of its narrative "naturalizing / romanticizing" and its conceptualization according to the model HUMAN BODY IS A NATURAL PHENOMENON Or NATURAL PHENOMENON / ABSTRACT PHENOMENON / ARTEFACT IS A HUMAN BODY, having narrative "modification" of eroticized body as its background. Eroticizing of postmodernistic body relies on its attributing narrative "artificiality" in terms of the conceptual metaphor HUMAN BODY IS AN ARTEFACT / ARTIFICIAL PHENOMENON / SIGN, and its "deviation" by means of the conceptual model EROTICIZED BODY IS A DEVIANT / PERVERSE BODY.

In literary texts of English modernism, "naturalizing / romanticizing" of the body corresponds to the overall tone of modernistic vision of eroticized body and is accompanied by its imagery conceptualization by means of metaphors:

- HUMAN BODY IS A NATURAL PHENOMENON / LANDSCAPE, actualized in $93 \%$ of text fragments, with human body as a target domain: Her breasts were pear-shaped [...] unripe, a little bitter (Lawrence LCL: 77), where breasts are conceptualized as pears on the basis of similar outlooks; or the most beautiful part of her [...] the haunches from the socket of the back and the buttocks. Like hillocks of sand (ibid: 75), where women's haunches, buttocks are compared to hillocks of sand;

- NATURAL PHENOMENON / LANDSCAPE IS A HUMAN BODY, actualized in $63 \%$ of text fragments in which body parts serve as source domains: like the dance of olive trees and their myriad-tongued grey leaves (Woolf W: 163), where the form of leaves is compared to a tongue (myriad-tongued leaves), or in the following fragments, where shell edge and river banks are metaphorically depicted as similar to lips (shells with red lips, river's lip): Twisted shells with red lips [...] ornamented the mantelpiece (Woolf VO: 9); They toiled along a tiny path on the river's lip (Lawrence SL: 285);

- ARTEFACT IS A HUMAN BODY (in $27 \%$ of text fragments): I love the telephone with its lip stretched to my whisper (Woolf W: 168), where telephone receiver is depicted as having lips (telephone with a lip);

- ABSTRACT PHENOMENON IS A HUMAN BODY (in $10 \%$ of text fragments): they had met in a naked extremity of hate (Lawrence SL: 353), where the feeling of hatred is eroticized by means of ascribing it the quality "nakedness" for emphasizing its frank and direct nature.

Unlike naturalized and romanticized narrativisation of the body in English modernism, eroticizing of the body in postmodernism prose takes place by means of accentuation of its "artificial" character and its "semiotization", accompanied on conceptual level by the metaphor HUMAN BODY IS AN ARTEFACT / ARTIFICIAL PHENOMENON / SIGN.

In literary interpretation of English postmodernism, the semiotic nature of the eroticized body is emphasized in conceptual metaphors HUMAN BODY IS A TEXT / MANUSCRIPT / BOOK / PALIMPSEST, that goes along with the general tendency of postmodernism to reality textualization (Дерріда 2001) and human body - in particular (Барт 1989). This tendency towards semiotization of eroticized body is lavishly observed in J.Winterson's "Written on the Body":

Written on the body is a secret code [...] the accumulations of a lifetime. The palimpsest is so heavily worked that the letters feel like Braille. I like to keep my body rolled up away from prying eyes. Never unfold too much, tell the whole story. I didn't know Louise would have reading hands (Winterson WB: 89 ).

Corporality acquires the qualities of a text, being metaphorically described as a surface on which the secret code (life experience of a character) is placed (written on the body is a secret code). The body 
getting the nature of a palimpsest with letters feeling like Braille, is kept rolled up, never unfolded in order not to tell the whole story.

In such imagery interpretation, the body's semiotic function is polymorphic: one lover's body is both the code itself and the surface for placing signs on it (a manuscript, a palimpsest), while the other lover's body is a decoder (translator, interpreter): Your hand prints are all over my body. You deciphered me and now I am plain to read. The message is a simple one, my love for you (ibid: 106); I will find a clue to you, I will be able to unravel you (ibid: 50). Conceptualization in terms of the metaphor SEX IS THE PROCESS OF ENCODING AND DECODING SIGNS is obvious in the following text fragment: She translated me into her own book (ibid: 89); Articulacy of fingers, the language of the deaf [...]. Who taught you to write in blood on my back? The pads of your fingers are printing blocks, you tap a message onto my skin, tap meaning into my body. Your morse code interferes with my heart beat (ibid: 89).

Linguistic markers of textual nature of eroticized body are nominations of types of codes (morse) code, language, letters, Braille, of means and result of encoding - write, print, tap message / meaning and their decoding - decipher, find a clue, unravel, translate, read.

According to the type of transformation of eroticized bodies in literary prose of English modernism and postmodernism different tendencies of narrativisation are observed. In modernistic vision eroticizing of the body takes place on the background of its "modification", accompanied by imagery conceptualization according to the model of characterization EROTICIZED BODY IS A MODIFIED BODY, while in postmodernistic narrative "deviation" of the body according to the conceptual model EROTICIZED BODY IS DEVIANT / PERVERSE BODY predominates.

The actualization of the narrative pattern "modification" implies transformation of the body with its transfer to another state that verbally takes place with the help of metamorphosis as a means of imagery formation and cognitively is based on the integration of analogous and converse means of conceptualization (Bielekhova 2002).

In literary texts of English modernism, the following three types of metamorphoses in imagery formation of eroticized body are singled out:

1) metaphorical changes of consistence of human body which can figuratively be in any possible physical state of a substance - being modified from solid to liquid one, the state of gas or plasma, it melts or dissolves. It usually happens under the influence of high temperature caused by the interaction of male and female bodies and implies conceptualization of female body by means of the metaphors HUMAN BODY IS ICE / AIR, of male body - HUMAN BODY IS FIRE: She melted under his touch (Lawrence LCL: 112); She was lighter than air, dissolving [...] with ecstasy (ibid: 147); His fire made her body melt (ibid: 214). Textual signals of this type of metamorphosis nominate transformations with the transfer to other state or acquiring new qualities - melt, become lighter than air, dissolve;

2) metamorphoses based on metaphorical conceptualization according to the model HUMAN BODY IS A NATURAL OBJECT, THAT IS BEING TRANSFORMED. It can be illustrated with the conceptual metaphor HUMAN BODY IS A FOREST THAT UNDERGOES CHANGES IN SPRING, where forest in the course of natural metamorphoses in spring is a metaphorical correlate of a female body: She was [...] like a forest soughing with the dim, glad moan of spring, moving into bud [...] she felt him and his child. His child was in all her veins, like a twilight (Lawrence LCL: 117); She was like a forest, humming inaudibly with myriad unfolding buds (ibid). Textual signals of narrative pattern "modification" in these text fragments are not only verbal markers of transformation of forest in spring (moving into bud, unfolding buds), but also spring, twilight as threshold symbols of transfer - spring as the beginning of new life cycle, twilight symbolizing prelude to a new cycle of being; 
3) the most complicated type of metamorphosis implies the change of roles of source and target domains, i.e. metaphorical conceptualization of HUMAN BODY as target-domain in terms of source-domain, where the latter is transformed into a target-domain (HUMAN BODY).

This type of metamorphosis is illustrated by the fragment of D.H. Lawrence's "Lady Chatterley's Lover", where the inversion of metaphorical correlates is observed - from water space (sea, ocean) as a correlate of a woman's body to a female corporality as a correlate of water space in its transformations, generalized by means of conceptual metaphor HUMAN BODY IS A WATER SPACE IN THE STATE OF TRANSFORMATIONS $\rightarrow$ CHANGING / MOVING WATER SPACE IS A PROCESS OF FEMALE NATURE BIRTH, e.g.:

she was like the sea, dark waves rising and heaving, [...] and she was Ocean rolling its dark, dumb mass. [...] far down inside her the deeps parted and rolled asunder, [...] the heavier the billows of her rolled away to some shore, uncovering her [...] further rolled the waves of herself away, leaving her, till in a soft, shuddering convulsion [...] she was born: a woman (Lawrence LCL: 152).

Textual signals of the vector of conceptualization EROTICIZED HUMAN BODY IS A WATER SPACE are comparisons and metaphors where the body is compared to the sea (she was like the sea) or the ocean (she was Ocean rolling its mass). At the same time the body of a woman in sexual intercourse is similar to an object moved by the sea waves until it turns out to be on the shore (the billows of her rolled away to some shore, uncovering her), that in imagery interpretation of the author symbolizes the birth of a woman (she was born: a woman).

This metamorphosis is based on converse type of mapping with the elements of parabolic one due to its similarity to the birth of Aphrodite from the depth of the sea. Such comparison is also enriched by the symbolic meaning of rough waters associated with female loins and womb. "Birth" symbolizes new psychology of a woman - free in openness of her feelings - granted to her by a beloved man.

The process of eroticizing the body in literary texts of English takes place by means of conceptual model of characterisation EROTICIZED BODY IS A DEVIANT / PERVERSE BODY. It is traced in many literary texts of English postmodernism (P. Ackroyd, J. Fowles, J. Winterson, F. Weldon, A. Burgess, I. Waugh, etc.). Deviant body experience includes psychopathologies of realization of libido in an unusual or untraditional way or choice of sexual object, that are called sexual deviations or perversions.

Perversions of psycho-physiology of the body as an instance of sexual deviation is observed in the text of F. Weldon's novel "Life and Loves of a She-devil", where Judge Bissop liked to beat his partner cruelly in sadistic sexual act: he subjected her to extreme sexual practices [...] nipped her nipples with his teeth (Weldon LLSD: 164), demonstrating passion for bondage and whips (ibid: 168), causing body damage to his lovers: bruises and abrasions (ibid: 176). At the same time his passion Polly Patch also tended to masochism, getting pleasure from painful sexual experience: The judge, finding a willing sexual partner in Polly [...] binding her hand and foot to the bed, beating her; only relief would be violent physical contact with her, some kind of sexual mauling (ibid: 171).

Among textual signals of narrative pattern "deviation" there are lexical units nominating acts of violence (binding, beating, sexual mauling, violent physical contact, nip), and the results of body damage (bruise, abrasion).

All in all in literary interpretation of corporality in English modernism imagery and symbolic means of nomination of the eroticized body dominate ( $92 \%$ ) compared to predominant quantity of denotative $(60 \%)$ and imagery means $(38 \%)$ in English postmodernism. It is explained by much more exposed narrativisation of eroticism and sexual relations in postmodernistic prose, usually done by means of direct nomination, while for the formation of a romanticized vision of eroticized body in English modernism the usage of allegoric and figurative means is characteristic. The range 
of cognitive mechanisms applied in the course of imagery interpretation of the eroticized body comprise analogous (metaphor, parabola), converse (metamorphosis) and associative (metonymy) conceptual tropes, demonstrating common principles of aesthetic thinking. On the verbal level in narrativisation of the body in English modernism quantitatively prevail local and localized (96\%), whereas global means of verbal signals dominate in postmodernism.

Socialized body as a means of verbalization and narrativisation of the conceptual metaphor HUMAN BODY IS AN OBJECT / RESULT OF SOCIETY IMPACT is constructed by means of ascribing it such qualities as "artificiality" and "semiotization" in terms of a conceptual pattern HUMAN BODY IS AN ARTIFCIAL PHENOMENON / ARTEFACT / SIGN, accompanied by actualization of the narrative pattern "socializing". Specific features of corporality vision in modernist and postmodernist literary texts are obvious in view of transformation of the body. Socialized body is constructed against the background of its narrative "deformation" in the analysed English modernism literary texts, which takes place in accordance with the conceptual metaphor SOCIALIZED BODY IS A DEFORMED BODY, and its "destruction" in the literary texts of English postmodernism according to the conceptual pattern SOCIALIZED BODY IS A RUINED BODY.

The narrative pattern "deformation" actualized in literary texts of English modernism to emphasize the ruining effect of society on a person in imagery plane is accompanied by nomination of integrity loss, changes in size, consistence of the body or its damage and painful bodily experience standing for psychological discomfort, emotional and mental suffering of a person in up-to-date society: She [...] stood alone [...] feeling herself suddenly shrivelled, aged, breastless, [...] out of her body and brain which now failed, since Lady Bruton [...] had not asked her (Woolf MD: 23). The abovementioned text fragment illustrates the conceptual metonymy DEFORMED BODY stands for DEPRESSED PERSON applied by V. Woolf to describe psychological state of Mrs. Dalloway rejected by society being not invited to the party. It is performed by means of description of her body as a deformed one - shrivelled, aged and even deprived of gender property - breastless.

Applying the image of a WAX FIGURE as a metaphorical correlate of a HUMAN BODY in the course of literary interpretation of socialized body, V. Woolf verbally designates the result of social factors impact as melting of certain parts of wax coat depending on life experience of a person: we were all different. The virginal wax that coats the spine melted in different patches for each of us (Woolf W: 241). With age this wax coat melts and drops off - that is the way a person wastes his/her body away in social surrounding: my waxen waistcoat melted, here one drop, there another (ibid: 237); It is not age, it is that a drop has fallen; another drop (ibid: 271), that accentuates human vulnerability to hard life experience in the society, that has a deforming effect both on his/her body and soul.

In literary texts of English postmodernism, socializing of the body takes place on the background of its "destruction" according to the conceptual pattern of characterization SOCIALIZED BODY IS A RUINED BODY.

Narrative pattern "destruction" accompanied by "semiotization" of the body by means of accentuation of its discursive nature is observed in P. Ackroyd's novel "Dan Leno and the Limehouse Golem" where the author applies to the conceptual metaphor HUMAN BODY IS A DISCOURSE while giving description of a murder:

Another female prostitute was found lying against the small white pyramid in front of the church of St Anne's. Her neck had been broken, and her head unnaturally turned so that she seemed to be staring just beyond the church itself; her tongue had been cut out and placed within her vagina, while her body itself was mutilated [...]. Upon the pyramid the word 'golem' had been traced in the blood of the dead woman (Ackroyd DLALG: 6). 
In the abovementioned text fragment the significant fact is a combination of verbal signs (the word 'golem' had been traced in the blood of the dead woman), with non-verbal, corporeal signs, i.e. pose, face expression, location and the way of positioning of the dead body and its fragments. In particular, the head turn and direction of eyes of the victim (she had been gazing at the workshop where the Analytical Engine waited to begin its life (ibid: 124) are a part of corporeal "message" which the murderer uses to "inform" of a real murderer. The murdered body as if "tells" who is to blame in crimes by means of pointing to the place of engineering the mechanism that as if deprives humans of their souls: Perhaps Analytical Engine was the true Limehouse Golem, draining away the life and spirit of those who approached it [...] digits and numbers were little chattering souls trapped in the mechanism, and its webs of iron no less than the web of mortality itself (ibid: 147). In such a way the dead body becomes a "narrative" instrument in a murderer's hands, "dwelling" on the nature of social fears concerning fast development of technologies in the $20^{\text {th }}$ century with attempts of creating artificial mind and other mechanisms aimed at substituting functions of a human as surrogate forms of life.

The body under power as a variety of a socialized body in literary texts of English postmodernism becomes the object of imagery and narrative interpretation under the influence of destructive events of the $20^{\text {th }}$ century. On the narrative level it is accompanied by actualization of a narrative pattern "destruction", on the conceptual - by the selection of natural phenomena, which are fragile, as metaphorical correlates for the body that implies conceptual metaphor HUMAN BODY IS A PLANT / INSECT, e.g.: 'I collect butterflies' 'Now you've collected me. You've pinned me in this little room and you can gloat over me [...] never let me fly away' (Fowles C: 42).

Gender aspect of socialized body interpretation demonstrates common and specific features of linguopoetics of English modernism and postmodernism. The common ones concern imagery representation of destructive processes of the body under the influence of masculinecentred society. It is accompanied by the conceptualization of a female body through the prism of natural phenomena while a male body acquires metaphorical correlates among artefacts as the products of civilization. Specific features are obvious in the poetics of postmodernism in view of eliminating gender body (as in J. Winterson's novels) or its complete deconstruction as in F. Weldon's "The Life and Loves of a She-Devil": We can reshape the body quite dramatically! (Weldon LLSD: 235), can use chip technology, microsurgery (ibid: 236).

All in all in literary interpretation of corporality in English modernism imagery means of nomination of the socialized body dominate (87\%) compared to predominant quantity of denotative $(62 \%)$ and imagery-symbolic means $(38 \%)$ in English postmodernism. Verbal level demonstrates common features as in narrativisation of the body in both English modernism and postmodernism global verbal signals (67 \% and $76 \%$ respectively) prevail quantitatively. Cognitive processes involved in the imagery interpretation of a socialized body embrace analogous and associative mechanisms and their combinations.

\section{Conclusions}

This study of linguistic aspects of corporality in literary texts of English modernism and postmodernism, marked by the introduction of the cognitive-semiotic approach to the field of linguopoetic research, enabled the interpretation of literary corporality as a linguopoetic category.

The results obtained are of practical significance for widening epistemic attainments of cognitive poetics due to the application of the cognitive-semiotic approach to the analysis of literary text as a polycode system, as well as for introducing a new cognitive-semiotic branch in linguopoetic research of corporality.

The methodology of cognitive-semiotic analysis applied to the study of corporality in literary texts of English modernism and postmodernism can be employed for the investigation of corporality as a linguopoetic category in literary texts of other epochs, written in other languages, of other types 
of texts, as well as be extended to other categories actualized in literary texts. I hope my generalizations concerning fictionalized body narrative patterns in literary texts of English modernism and postmodernism will be a contribution to cognitive poetics, literary text semiotics, and cognitive narratology and open up new perspectives for their further investigation in English and other languages.

\section{REFERENCES}

Alieva, T.M. (2010). Polisemantism somaticheskoy leksiki v raznosistemnyh jazykah [Polisemy of somatic vocabulary in languages of different types]. PhD Diss. Makhachkala. (in Russian).

Arkadiev, P.M., Kreidlin, G.Ye., Lietuchiy, A.B. (2008). Emioticheskaya kontseptualizatsija tela I jego chastei. I. Pryznak «Forma». [Semiotic conceptualization of human body and its parts.

I. Quality «Form»]. Voprosy jazikoznanija. № 6. P. 78-97 (in Russian).

Barthes, R. (1989). Izbrannyie raboty: Semiotika. Poetika. [Selected works: Semiotics. Poetics]. Moscow: Progress. (in Russian).

Bieliekhova, L. I. (2002). Slovesnyi poetychnyi obraz $v$ istoryko-typologichniy perspektyvi: lingvokognityvnyi aspekt (na materiali amerykanskoi poezii) [Verbal poetic image in historico-typological perspective: linguokognitive aspect (on the poetry of America writers)]. Kherson: Ailant. (in Ukrainian).

Bogumil, M. L. (1988). Joyce's use of synaesthsia: The intra- and inter-episodic recurrence of sensory impressions in Ulysses: Ph.D. diss. Ann Arbor: University of South Florida.

Bykhovskaya, I. M. (2000). "Homo somatikos»: aksiologija chelovecheskogo tela ["Homo somatikos»: axiology of human body]. Moscow: Editorial URSS. (in Russian).

CCT (1997). - Collins Concise Thesaurus / ed. A. Holmes, M. O’Neil, I. Brookes, E. Summers. Glasgow: Harper Collins.

Derrida, J. (2001). Struktura, znak i gra u dyskursi gumanitarnyh nauk. Slovo. Znak. Dyskurs: Antologija svitovoi literaturno-krytychnoi dumky XX stolittia. Lviv: Litopys. P. 617-632. (in Ukrainian).

DFEL. - Dictionary of Frequency of the English language. Retrieved from: www.wordfrequency.info.

Dirven, R., Verspoor, M. (2004). Cognitive Exploration of Language and Linguistics. Amsterdam: John Benjamins.

Gallagher, Sh. (2006). How the Body Shapes the Mind. Oxford: OUP.

Gudkov, D. B., Kovshova, M.L. (2007). Telesny kod russkoi kultury: materialy $k$ slovariu [Corporeal code of Russian culture: materials to the dictionary]. Moscow: Gnosis. (in Russian).

Gundorova, T. (2010). Symptomatyka «hvorogo tila» [Simptoms of «ill body»]. Krytyka. 2010. Is. 7-8 (153-154). P. 24-28. (in Ukrainian).

Frolova, S. V. (2000). Chelovecheskaya telesnost: ontologicheskije nachala i filosofskije osnovanija [Human corporality: onthological initials and philosophic grounds]: PhD Diss. Saratov. (in Russian).

Ibarretxe-Antuñano, I. (2002). MIND-AS-BODY as a cross-linguistic conceptual metaphor. Miscelánea. A Journal of English and American Studies. No 25. P. 93-119.

Khrabrova, G. M. (2001). Hudozhnya visija tilesnosti v epohu Vidrodzhennja: aksiologija, semantyka i providni modeli representatsii [Literary vision of corporality in the Renaissance period: axiology, semantics and main patterns of representation]. Scientific works. Philology. Literature studies. Mykolaiv: Petro Mohyla MSU. P. 86-90. (in Ukrainian).

Klevtsova, O. B. (2007). Kontsept «chelovek telesny»: kognitivnoje modelirovanie i perenosy [Concept «Homo corporalis»: cognitive modelling and transfers]: PhD Diss. Tumen: TSU. (in Russian).

Knyazeva, Ye. (2009). Telesnaja priroda soznanija [Corporeal nature of consciusness]. Телесность как эпистемологический феномен / ed. by I. A. Beskova. Moscow. P. 31-54. (in Russian). 
Koretskaya, L. F. (2006). Telesnost cheloveka kak objekt sotsiogumanitsrnogo poznanija [Human corporality as an object of socio-humanitarian comprehension]. Bulletin of Irkutsk state Academy of Economics. № 1 (46). P. 69-74. (in Russian).

Korotun, O. V. (2002). Obraz-kontsept «Vneshnij chelovek» v russkoj jazykovoj kartine mira [Image-concept «External human being»in Russian linguistic picture of the world]: PhD Diss. Omsk. (in Russian).

Kövecses, Z. (2002). Metaphor: A Practical Introduction. Oxford: Oxford University Press.

Krutkin, V. L. (1997). Telesnost cheloveka v ontologicheskom izmerenii [Human corporality in onthological vision]. Social sciences and the present. № 4. P. 143-151. (in Russian).

Kulichikhina, M. A. (2012). Telo i telesnost $v$ nemetskom romantizme: kontseptsii i obrazy [Body and corporality in German Romanticism: conceptions and images]: PhD Diss. Moscow. (in Russian).

Lakoff, G., Johnson, M. (1980). Metaphors We Live by. Chicago: University of Chicago Press.

Langacker, R. W. (1990). Concept, image, and symbol: The cognitive basis of grammar. Berlin and New York: Mouton de Gruter.

Marmaridou, S. (2011). The relevence of embodiment to lexical and collocational meaning: The case of prosopo 'face' in Modern Greek. Embodiment via body parts / ed. Z. Maalej \& N. Yu. Amsterdam: John Benjamins. P. 23-40.

Materynska, O. V. (2009). Typologiya naimenuvan chastyn tila [Typology of body parts nominations]. Donetsk. (in Ukrainian).

Merleau-Ponti, M. (1999). Fenomenologija vosprijatija [Phenomenology of perception]. Saint Petersbourg: Yuventa. (in Russian).

Mescheriakova, O. A. (2011). Semantyka pertseptsii $v$ aspekte hudozhestvennoi kognitsii I.A. Bunina [Semantics pf perception in the aspect of literary cognition of I.A. Bunin]: PhD Diss. Moscow. (in Russian).

Nasalevich, T. V. (2003). Portretnyi opys u riznyh typah tekstu [Portrait description in different types of texts]: PhD Diss. Odessa. (in Ukrainain).

Ostry, M. V. (2007). Problema telesnosti v zapadnom iskusstve XX veka: ontologicheskij aspekt [Problem of corporality in Western art of XX century]: PhD Diss. Samara. (in Russian).

Perminova, A. V. (2003). Vidtvorennia angliiskoi sensornoi leksyky $v$ ukrainskih virshovyh perekladah [Representation of English sensory lexicon in Ukrainian poetry translations]: PhD Diss. Kiev. (in Ukrainian).

Podoroga, V. A. (1995). Fenomenologija tela. Vedenije v filosofskuju antropologiju [Phenomenology of a human body. Introduction into philosophic antropology]. Moscow: Ad Marginem. (in Russian).

Poltarobatko, Ye. D. (2009). Kategorija telesnosti v akmeisticheskom diskurse [Category of corporality in acmeism discourse]: PhD Diss. Moscow. (in Russian).

Rosch, E. H. (1978). Principles of Categorization. Cognition and Categorization. Hillsdale, New York: Lawrence Erlbaum. P. 27-48.

Seryakova, I. I. (2012). Somatikon англомовних дискурсивних практик [Somaticon of Anglophone discursive practice]: Diss. of Doctor of Science. (in Russian).

Shteinbuk, F. M. (2006). Antropologichnist tilesnosti v tekstovyh strategijah suchasnoi literatury v konteksti vidnoshennja do vlasnogo tila [Anthropology of corporality in textual strategies of contemporary literature in the context of attitude to the own body]. Culture of the Black Sea peoples. № 92. P. 86-90. (in Ukrainan).

Shtokhman, L. M. (2008). Antropologija naratsii: stat, gender i seksualnist v romani J. Winterson «Tainopis ploti» [Antropology of narration: sex, gender and sexuality in J. Winterson's novel «Written on the Body»]. Studia methodologica: "Antropology of literature: communication, language, corporality». Vol. 25. Ternopil. P. 284-287. (in Ukrainian). 
Skachkov, A. Yu. (2007). Лінгвостилістичні особливості портретних описів у творах M. Коиюбинського [Linguostylistic features of portrait descriptions in M. Kotsubinsky's novels]: PhD Diss. Kharkiv. (in Ukrainian).

Soloschuk, L.V. (2006). Verbalni i neverbalni komponenty kominikatsii v anglomovnomu dyskursi [Verbal and non-verbal components of communication in Anglophone dicourse]. Kharkiv: Konstanta. (in Ukrainian).

Starostina, Yu. A. (2009). Kontsepty «zapah» i «krasota» v romane P. Suskinda «Parfumer. Istoria odnogo ubiytsy» [Concepts of «smell» and «beauty» in P.Suskind's novel «Perfume. The Story of a Murderer»]. Bulletin of Volgograd state university. Philology. № 7 (41). P. 164169. (in Russian).

Stetsiura, L. V. (2010). Kontseptosphera «organism cheloveka» v professionalnoi kartine mira medika [Domain «human organism» in the professional picture of the world of a medical worker]: PhD Diss. Cheliabinsk. (in Russian).

Tataru, L. V. (2007). Predstavlenie kontsepta «Telo cheloveka» v компоkompozitsionno-narrativnoi strukture modernistskogo teksta [Interpretation of the concept «Human body» in compositional and narrative structure of a modernist text]. Bulletin of SPbU. Philology, Eastern languages studies, journalism. Vol. 4 (P. II). P. 68-77. (in Russian).

Turaieva, Z. Ya. (1979). Kategorija vremeni. Vremja grammaticheskoye $i$ vremja hudozhestvennoje [Category of time. Grammatical and literary time]. Moscow: Vysshaja shkola. (in Russian).

Turner, M. (1998). The Literary Mind: The Origins of Thought and Language. Oxford: OUP.

Verbytska, O. (2009). Tilo jak tekst: semiotyka postmodernistychnogo rozuminnja [Human body as a text: semiotics of postmodernistic understanding]. Bulletin of Lviv University. Phylosophy. Is. 12. P. 85-91. (in Ukrainian).

Violi, P. (2010). How our bodies become us: Embodiment, semiosis and intersubjectivity. Journal of Cognitive Semiotics: The Intersubjectivity of Embodiment. Vol. 4. No. 1. P. 56-75.

Vorobyova, O. P. (1993). Lingvisticheskiye aspekty adresovannosti hudozhestvennogo teksta [Linguistic acpects of addressedness of a literary text]: Diss. of Doctor of Science. Moscow. (in Russian).

Vorobyova, O. P. (2012). Smak «shokoladu»: intermedialnist i emotsiinyi rezonans [Taste of «chocolate»: intermediality and emotional resonance]. Bulletin of Kiev National Linguistic University. Philology. 2012. Is. 15. № 1. P. 5-11. (in Ukrainian).

WTNIDEL (1993). - Webster's Third New International Dictionary of the English Language (Unabridged) / ed. Ph. Gove. Cologne: Konemann.

Yeliferova, M. V. (2007). Telesnost i metafora ploti v «Venetsianskom kuptse» [Corporality and metaphor of flesh in «Venetian Merchant»]. Shakespear studies VII. P. 45-55.

Zalevskaya, A. A. (2005). Korporealnaya semantika i integrativnyi podhod k jazyku [Corporeal semantics and integrative approach to a language]. Psycholinguistic studies. Word. Text. Moscow: Gnosis. P. 245-255. (in Russian).

Zamoiska, I. (2004). Struktura slovotvirnyh paradygm imennykiv na poznachennja vnutrishnih organiv liudyny [The structure of word-forming paradigms of nouns nominating internal organs of a human being]. Bulletin of Lviv university. Phylology. P. 1. Vol. 34. P. 153-158. (in Ukrainian).

Ziemke, T. (2003). What's that thing called embodiment? Proceedings of the 25th Annual Meeting of the Cognitive Science Society / ed. by R. Alterman, D. Kirsh. Mahwah, New York: Lawrence Erbaum. P. 1305-1310.

Zlatev, J. (2008). The co-evolution of intersubjectivty and bodily mimesis. The Shared Mind: Perspectives on Intersubjectivity / ed. J. Zlatev, T. Racine, C. Sinha, E. Itkonen. Amsterdam: Benjamins. P. 215-244. 


\section{DATA SOURCES}

Ackroyd DLLG. - Ackroyd, P. (1995). Dan Leno and the Limehouse Golem or The Trial of Elisabeth Cree. London: Minerva.

Ackroyd HHD. - Ackroyd, P. (1994). The House of Doctor Dee. London: Penguin Books.

Ackroyd L. - Ackroyd, P. (2003). London. A Biography. London: Anchor.

Fowles C. - Fowles, J. (1997). The Collector. London: Back Bay Books.

Fowles ET. - Fowles, J. (1999). The Ebony Tower. London: Back Bay Books.

Lawrence LCL. - Lawrence, D. H. (2011). Lady Chatterley's Lover. New York: Empire Books.

Lawrence PO. - Lawrence, D. H. (1995). The Prussian Officer. The Prussian Officer and Other Stories. London: Penguin Group. P. 1-21.

Lawrence FSG. - Lawrence, D. H. (1995). Fragment of Stained Glass. The Prussian Officer and Other Stories. London: Penguin Group. P. 88-98.

Lawrence EME. - Lawrence, D. H. (2011). England, My England. England, My England. New York: CreateSpace. P. 1-28.

Lawrence SL. - Lawrence, D. H. (2011). Sons and Lovers. New York: Empire Books.

Lodge T. - Lodge, D. (2002). Thinks. London: Penguin books.

Rushdie MC. - Rushdie, S. (2006). Midnight Children. London: Random House.

Weldon LLSD. - Weldon, F. (1993). The Life and Loves of She-Devil. London: Ballantine Books.

Winterson WB. - Winterson, J. (2001). Written on Body. London.

Woolf W. - Woolf, V. (2000). The Waves. London: Wordsworth Editions.

Woolf VO. - Woolf, V. (2011). Voyage Out. New York: CreateSpace.

Woolf MD. - Woolf, V. (2010). Mrs. Dalloway. A Room of One's Own. Houghton Mifflin.

Woolf LL. - Woolf, V. (2002). Lappin and Lapinova. A Haunted House and Other Short Stories.

Orlando: Mariner Books. P. 68-79.

Woolf TA. - Woolf, V. (2002). Together and Apart. A Haunted House and Other Short Stories. Orlando: Mariner Books. P. 136-144.

Iryna Galutskikh - PhD, Associate Professor of English Philology Chair at the Department of Foreign Philology of Zaporizhzhya National University, (66, Zhukovskogo st., Zaporizhzhya, Ukraine). E-mail: iryna.galutskikh@gmail.com. ORCID: 0000-0003-4263-942X. Google Scholar profile: https://scholar.google.com.ua/citations?user=pXWcVo4AAAAJ\&hl=ru

Ірина Анатоліївна Галуцьких - доктор філологічних наук, доцент кафедри англійської філології Запорізького національного університету, (66, вул. Жуковського, м. Запоріжжя, Україна). E-mail: iryna.galutskikh@gmail.com. ORCID: 0000-0003-4263-942X. Google Scholar profile: https://scholar.google.com.ua/citations?user=pXWcVo4AAAAJ\&hl=ru

Ирина Анатолиевна Галуцких - доктор филологических наук, доцент кафедры английской филологии Запорожского национального университета, (66, ул. Жуковского, г. Запорожье, Украина). E-mail: iryna.galutskikh@gmail.com. ORCID: 0000-0003-4263-942X. Google Scholar profile: https://scholar.google.com.ua/citations?user=pXWcVo4AAAAJ\&hl=ru 


\section{NARRATIVE TENSION WITHIN THE FRAMEWORK OF COGNITIVE MODELING Hanna Leshchenko (Cherkasy, Ukraine)}

H. Leshchenko. Narrative tension within the framework of cognitive modeling. This paper discusses cognitive linguistic foundations of narrative tension, defined as a particular way of story arrangement aimed at getting the reader's immediate cognitive response, accompanied by intense excitement exposed through the emotional states of fearful apprehension (suspense), curiosity and surprise. Narrative tension, as a part of the general interpretation program possessed by a literary text, is incorporated into its narrative structure. Since research on narrative tension is still being launched, numerous aspects of its evoking and maintaining remain undisclosed so far.

In this paper I propose an authentic methodology for cognitive modeling of narrative structure. Being a part of cognitive linguistic analysis of narrative tension incorporated in a narrative structure, cognitive modeling helps to conceptualize the complicated nature of the narrative proper, as well as to unify the principles of its studying.

Key words: cognitive modeling, cognitive proto-structures of narrative, narrative tension, narrative phases, narrative structure, thematic macrostructures.

Г.Лещенко. Наративна напруженість у світлі когнітивного моделювання. У статті розглянуто лінгвокогнітивні засади наративної напруженості, потрактованої як особливий спосіб побудови історії, що викликає безпосередню когнітивну реакцію читача, супроводжувану емоційними реакціями саспенсу, зацікавленості або збентеженості. Наративна напруженість, як частина загальної програми інтерпретації художнього твору, вбудована у його наративну структуру. Оскільки вивчення наративної напруженості лише розпочинається, багато аспектів, пов'язаних із ії виникненням i утримуванням, залишаються недослідженими.

У статті запропоновано методику когнітивного моделювання наративної структури художнього тексту. Як частина загальної програми інтерпретації наративної напруженості, вбудованої у структуру наративу, когнітивне моделювання дозволяє, 3 одного боку, висвітлити складну сутність аналізованого феномена, а з іншого - уніфікувати принципи його аналізу.

Ключові слова: когнітивне моделювання, когнітивні протоструктури наративу, наративна напруженість, наративна структура, наративні фази, тематичні макроструктури.

А. Лещенко. Нарративная напряженность в свете когнитивного моделирования. В статье рассмотрены лингвокогнитивные основания нарративной напряженности, определяемой как особый способ построения истории, который вызывает непосредственную когнитивную реакцию читателя, сопровождаемую эмоциональными реакциями саспенса, любопытства или замешательства. Нарративная напряженность, как часть общей программы интерпретации художественного произведения, встроена в его нарративную структуру. Поскольку изучение нарративной напряженности только начинается, многочисленные аспекты, связанные со спецификой ее возникновения и удержания, остаются неисследованными.

В статье предложена методика когнитивного моделирования нарративной структуры художественного текста. Как часть общей программы интерпретации нарративной напряженности, встроенной в структуру нарратива, когнитивное моделирование позволяет, с одной стороны, прояснить сущность анализируемого феномена, а с другой - унифицировать принципы его анализа.

Leshchenko H., 2018 
Ключевые слова: когнитивное моделирование, когнитивные протоструктуры нарратива, нарративная напряженность, нарративная структура, нарративные фазы, тематические макроструктуры.

\section{Introduction}

The present paper discusses cognitive linguistic foundations of narrative tension, resulted from the author's strategy of text building aimed to arouse, maintain, and intensify the reader's interest to the text.

The paper reviews some central insights on narrative tension that come from the domain of cognitive narratology, which 'posits mental processes of perception and understanding and relies on models that are derived from how people deal with texts, foregrounding the conceptual schemata that operate in people's mind' [Fludernik \& Olsen 2011: 8]. From this standpoint, the reading process is viewed as 'a complex mental operation: the mind sifts through information old and new, recognizes patterns, activates memory structures, and establishes, strengthens or realigns mental network connections' [Reichle 2009: 16]. Therefore, the narrative itself is considered as not only a telling, but as a repository of mental representations, i.e. mental structures which reconstruct the actual world in a human's mind and implement the individual's knowledge about the world and the feelings he experiences while learning it [Shtern 1998: 214-215].

Given the applicability of cognitive approaches to studying narrative texts, with narrative tension embedded, this paper aims to develop a new methodology for building cognitive models of the narrative structure, as well as to reveal the complex mechanism of narrative tension inducing. Although this methodology is mostly based on the analysis of plot-oriented literary texts, the suggested principles of cognitive modeling of narrative structure can also be applied to narrative texts of different genres and forms.

\section{The notion of 'tension' in linguistic studies}

In modern linguistics, tension is defined in different ways: as an attribute of language structures (Admoni 1969; Yeltsova 2006), as a property of communicative units of speech (Myshkina 1998), as a text category, manifested by means of multilevel (mainly lexical and syntactic) lingual units (Yudina 1990), as a phenomenon of language, literature and art (Fill 2003) etc.

Unlike Eastern European studies, in which tension is perceived as belonging to the text proper, in Western linguistics, the notion of tension is mostly associated with the receptive-textual phenomenon of reader interest to the text / narrative (Ryan 2005; Phelan 2006; Herman \& Vervaek 2009; Kuijpers 2014). Therefore, narrative tension is viewed from two perspectives - text-oriented and reader-oriented ones. From the text-oriented perspective, tension is a result of narrative organization evoking the reader's intellectual and emotional feedback, determined by the narrative past (retrospection / curiosity), the narrative future (prospection/suspense) and the narrative present (recognition / surprise) (Brewer \& Lichtenstein 1982; Dove 1989; Baroni 2016). From the reader-oriented perspective, tension is the reader's psychological response to the development of fictional / factual events. This response is formed by the interaction of three major constituents: uncertainty, expectation / anticipation and investment / engagement (Gerrig 1994; Carroll 1996; Cupchick 1996; Wulff 1996; Zillmann 1996).

Critical studying of the reviewed literature enabled me to combine both approaches and further define narrative tension as a particular way of story arrangement aimed at getting the reader's immediate cognitive response, accompanied by intense excitement exposed through the emotional states of fearful apprehension (suspense), curiosity and surprise. Narrative tension, as a part of the general 'interpretation program possessed by a literary text' [Vorobyova 2013: 44], is incorporated into its narrative structure. The description of such a program requires a new methodology for linguistic analysis of narrative tension, developed in the cognitive framework. The 
suggested analysis comprises two stages: (1) cognitive modeling of a narrative structure with the incorporated program of narrative tension, and (2) analysis of textual descriptions.

\section{Narrative structure as a key notion in cognitive narratology}

Cognitive narrative theory, or cognitive narratology, focuses on the mental representations and the cognitive structures that underlie narrative texts, both the actual texts and the reader's perception are being investigated. Therefore, the text proper is conceptualized in two perspectives: as a sequence of verbalized events (Bremond 1973; Larivaille 1974; Todorov 1981; Adam 2011) and as an inter-correlation of these events within the global theme of the narrative (Propp 1928; Greimas 1996; Tan 1996; Kintsch 1998). The key notion employed in both traditions - referential and hierarchical - is narrative structure, which is, respectively, studied in two ways: either as a narrative sequence of the events (formal aspect), or as a thematic situational model (content aspect). As Michael Bamberg and Virginia Marchman argue, these two traditions are not commonly found together (Labov \& Waletzky`s 1967 is an exception to this rule), despite the awareness that there is a complimentary simultaneous process of binding and unfolding between "local-level cohesive ties" and "global-level hierarchy" of the narrative organization [Bamberg \& Marchman 1991: 279]. The authors insist on bridging the linguistic form and conceptual structuring function, emphasizing a need for a comprehensive, coherent description of the narrative structure, embracing both formal and content peculiarities of its organization.

Following this claim, I consider the universal cognitive model of narrative structure to be an appropriate methodological tool for further investigations. This paper tends to describe its conceptual parameters and highlight some issues of its modification. The structural principles of this model are supposed to correlate with the general criteria of narrativity, as well as to meet the requirements of a particular genre. Evidently, the reader (as an implied agency) is also taken into account, when building the model. Being an initial stage of an authentic methodology for cognitive linguistic analysis of narrative tension, cognitive modeling of narrative structure is based on the fundamental theoretical studies in the field of narratology (Sternberg 2003a, 2003b; Ryan 2005; Herman 2009; Fludernik 2011).

\section{Theoretical grounds for cognitive linguistic analysis of narrative tension}

Accomplished studying of critical reviews on the issues of narrative structure, allowed me to formulate the fundamental principles for cognitive modeling, employed for cognitive linguistic analysis of narrative tension:

- The structure of the narrative unfolds along the horizontal and vertical axes. The horizontal, syntagmatic axis demonstrates, on the one hand, the process of verbalization (speech generating with the help of lingual means), and, on the other hand, the reference process (the development of the events narrated). The vertical axis of the narrative represents the thematic hierarchy of narrative events, as well as their subordination to the global narrative theme (Bamberg \& Marchman 1991).

- The global narrative theme is dependent on genre peculiarities. It is presented by thematic structure that regulates the reader's expectations for the development of narrative events (Tan 1996). The thematic structure of the global topic hierarchically includes macro- and microstructures. Microstructures that determine the propositional-semantic content of textual descriptions are united within the macrostructure, which is subordinate to the global structure (Kintsch 1998). Macrostructure is a situational model, i.e. a model of a text situation (Dijk \& Kintsch 1983). This hierarchy forms the semantic underpinning of the text, or the text base (Kintsch 1998).

- Narrative sequences that are cyclically reproduced in the text (Todorov 1981; Adam 2011) are conceptualized as a sort of macrostructures, which combine the propositional content of microstructures. These 'cycles' represented by a set of narrative phases 'Orientation - Complication Evaluation - Resolution - Coda' (Labov 1972), objectify a certain thematic unity. Within the narrative structure, those sequences are united by combining, embedding and interweaving 
(Todorov 1981). The whole text can contain several narratives, one of which is dominant, and the other is additional (Scott 2013).

- The narrative structure is characterized by built-in narrative tension (Scott 2013), evoked by 'narrative probabilities', conceived as 'bifurcation points' (Bremond 1973) in one or another narrative phase.

- The components of the reader's tension are his/her predictable emotional responses of suspense, curiosity and surprise (Brewer \& Lichtenstein 1982), attending prospection, retrospection and recognition (Sternberg 2003a, 2003b), being cognitive operations of text processing.

- Narrative projection into the reader 's mind is performed due to latent actional triggers (Sternberg 2003a), implanted in the surface representation of the text (Kintsch 1998).

All these claims lay the foundation of suggested methodology for cognitive modeling of narrative structure.

In my research, the minimal unit of formal and content segmentation of the narrative is represented by narrative episode. Although the definition of episode is not uniform, most scholars employ the notion elaborated by Van Dijk, when discussing the episodic structure of newsstories: 'Roughly speaking, paragraphs or episodes are characterized as coherent sequences of sentences of a discourse, linguistically marked for beginning and / or end, and further defined in terms of some kind of "thematic unity" - for instance, in terms of identical participants, time, location or global event or action' [Dijk 1982: 177].

Narrative episodes combined within the larger structural and compositional clusters, constitute narrative phases of Orientation, Complication, Evaluation, Resolution and Coda (except for Resume, correlated with the title). Any of these narrative phases may comprise one or more narrative episodes. The sequence of these phases, in which Complication and Evaluation can iterate time and again, forms a skeleton of the general cognitive structure of a narrative text, presented by its cognitive model. The building blocks of this model are represented by cognitive proto-structures of narrative prospection, retrospection, and recognition.

\section{Cognitive Proto-Structures of the Narrative: major issues}

Cognitive Proto-Structures of the Narrative (CPSN) are complex conceptual schemas which demonstrate (1) the sequence of narrative phases, (2) their thematic (conceptual) representation in terms of interrelated argument slots, and (3) the story's reader's response to the narrative time. This response consolidates a CPSN as a discrete coherent whole. With vectors of the narrative time in view, the CPSN are identified as prospection (the response WHAT WILL HAPPEN?), retrospection (the response WHAT HAPPENED?), and recognition (the response WHAT IS HAPPENING?).

(1) In CPSN, the syntagmatics of narrative phases represented by the sequence 'Orientation Complication - Evaluation - Resolution - Coda' is enabled by the repetition of Complications and Evaluations between the initial Orientation and the final Resolution / Coda.

(2) The thematic development of the narrative phases constituting the CPSN presupposes a macro-theme associated with a certain narrative event, with its participants are its actants. The actants of the macro-theme, united by some ACTION, form a thematic macrostructure, with its constituents are argument slots, provided in terms of Semantics of Lingual Networks (Zhabotynska 2013).

(3) In CPSN, the reader's response to the narrative time is represented by an intellectual component (prospection, retrospection, recognition), accompanied by an appropriate emotional component (suspense, curiosity, surprise).

In prospective CPSN (graphically, its components are hexagonal), in Complication the argument slots of the thematic macrostructure are filled, as a rule, with the specific information, or their content is specified during the plot movement. The only unfilled slot, up to Resolution, is OUTCOME supposing either a positive or a negative solution to the conflict and inducing tension 
and anxiety, or suspense. It is the process of filling this slot that serves a guarantee of retaining the reader`s interest to the narrative: WHAT WILL HAPPEN? (Fig. 1).

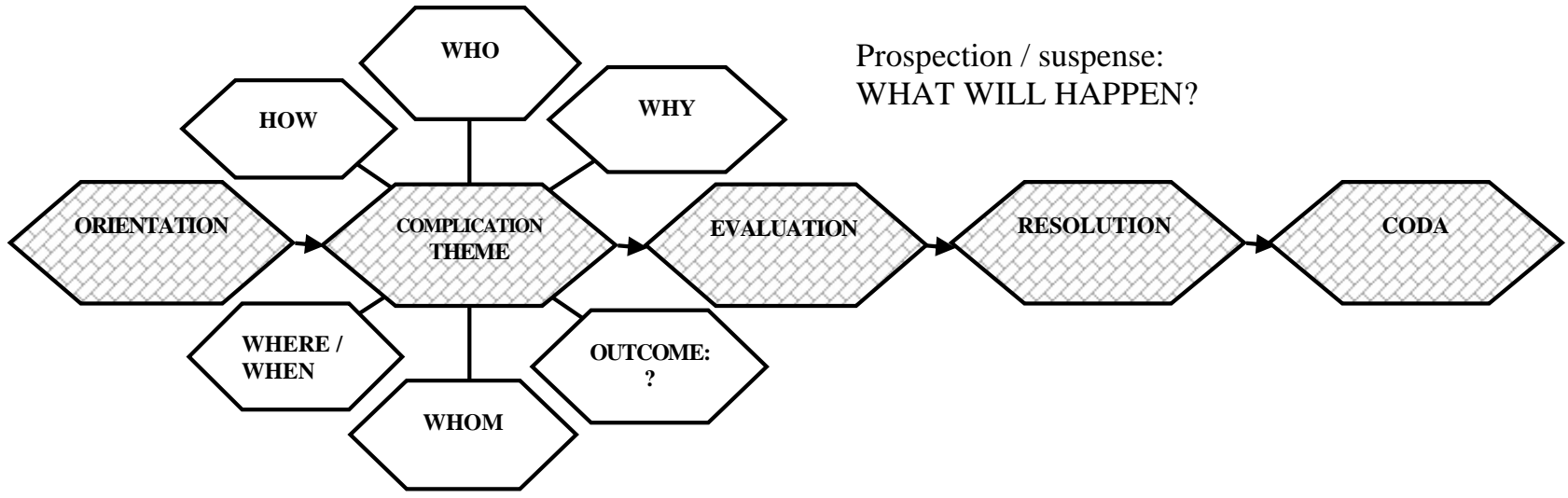

Figure 1. CPSN: prospection

Retrospective CPSN (graphically, its components are oval) demonstrates the uncertainty associated with the information deficit experienced by the reader. Thus, in thematic macrostructures of the narrative sequence, one or more slots appear to be unfilled up to Resolution, evoking the reader`s intense curiosity: WHAT HAPPENED? The induced tension is relieved in Resolution, where the initial set of roles is changing in some way, and is specified by means of gradually incoming story information, the narrative theme remains unchanged (Fig. 2).

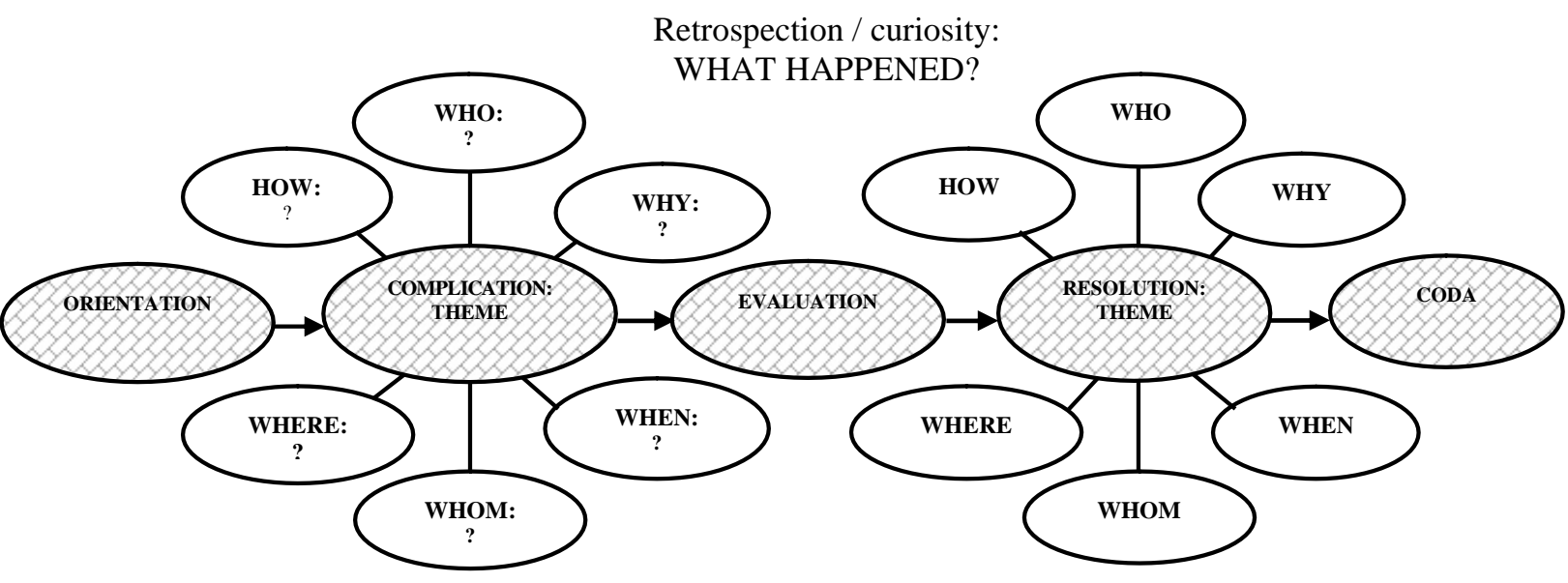

Figure 2. CPSN: retrospection

In recognitive CPSN (graphically, its components are rectangular), the mistaken interpretation of the data available, accomplished by the reader, generates in his mind the false thematic macrostructure in Complication (Theme 1). Then the reader's further awareness of his own mental miscalculations is fixed in Resolution, whereas the information concerning with the narrative events is organized within the framework of an absolutely different thematic macrostructure (Theme 2). While data processing, the reader experiences some difficulties that makes him feel a sort of surprise: WHAT IS HAPPENING? That cognitive-emotional confusion is removed in Resolution, where narrative events are reinterpreted in a proper way: Theme $1 \rightarrow$ Theme 2 (Fig. 3). 


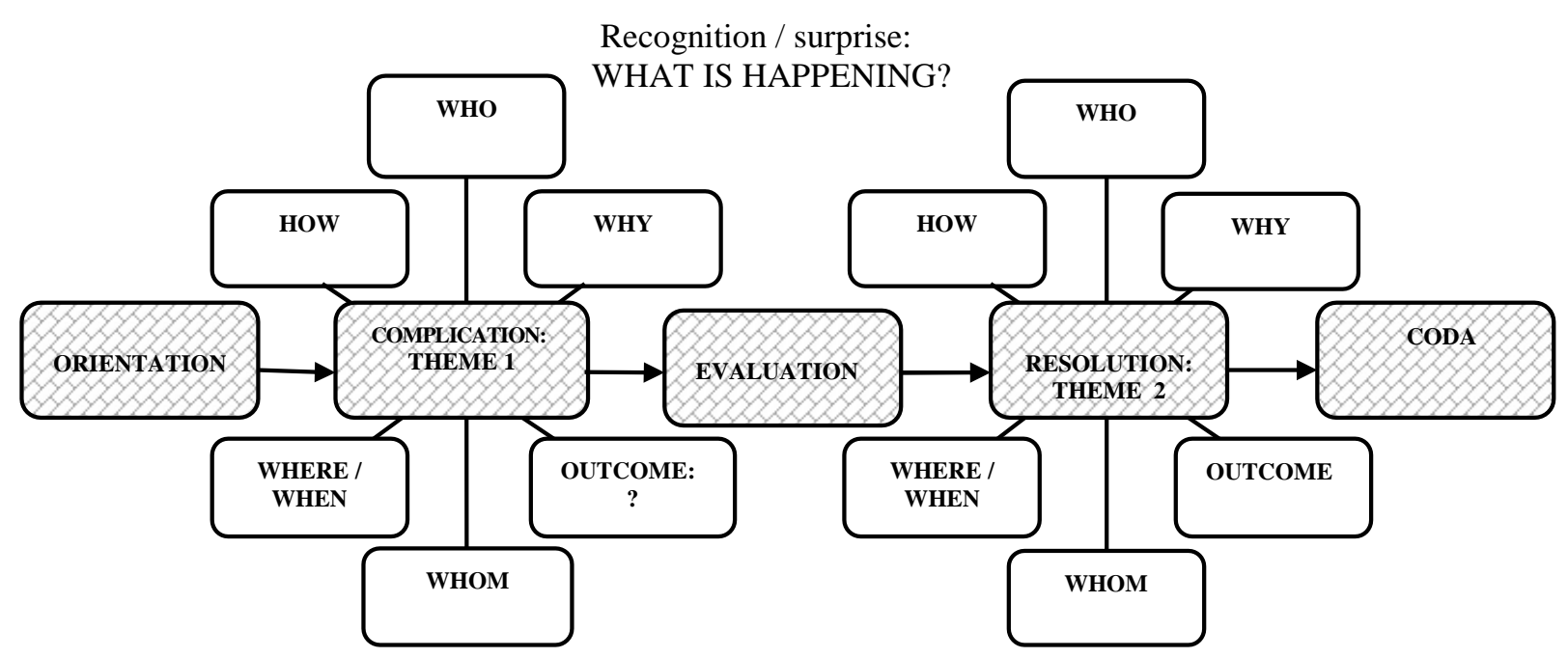

Figure 3. CPSN: recognition

These CPSN - prospective, reuuspecuve, anu ıecugnumve - vunu up cugnut ve models of the narrative structure inherent in particular texts. Such models are divided into simplexes and complexes. Cognitive simplexes are constituted by one of the three CPSN. Cognitive complexes, including two and more CPSN, demonstrate different ways of their combining (addition and inclusion), and are accordingly split into additive, inclusive, and additive-inclusive (see more details in [Leshchenko 2017]).

Based on CPSN, cognitive models of narrative structure meet the requirements of 'integrity': they demonstrate formal arrangement of the text through its narrative scheme and simultaneously introduce its semantic organization by means of interrelated thematic macrostructures, being reconstructed in narrative phases. With all apparent diversity, which reflects the peculiarities of specific narrative texts, their cognitive models are built on the identical principles and reproduce the unified cognitive proto-structures of the narrative.

\section{The methodology for cognitive modeling of narrative structure}

As I stated above, the suggested framework of cognitive linguistic study of narrative tension includes two stages: (1) cognitive modeling of narrative structure, and (2) analysis of textual descriptions. Since my paper focuses on cognitive modeling of the narrative, I tend to concentrate on the procedure itself, omitting the issue of verbal manifestation of the interpretation program of narrative tension.

Thus, the procedure of building cognitive models of narrative structure includes the following steps:

1) distinguishing the number of narrative episodes (NE) and fixing their correlation with the narrative phases (NP);

2) determining the thematic unfolding of NP in terms of argument slots;

3) representing the cognitive model of the story`s narrative structure with the help of conceptual graphics, a story`s transcript is supplemented.

For the demonstration of the elaborated method, Agatha Christie`s short story 'The Million Dollar Bond Robbery' (1) was taken.

The Million Dollar Bond Robbery

A - Philip Ridgeway, B - Mr. Vavasour, C - Mr. Shaw, D - Esmee Farquhar, E - Mr. Ventnor, FHercule Poirot. Narrative schema: 10 NE, 7 NP, 1 CPSN: \{Orientation /1/ - Complication /2-4/-

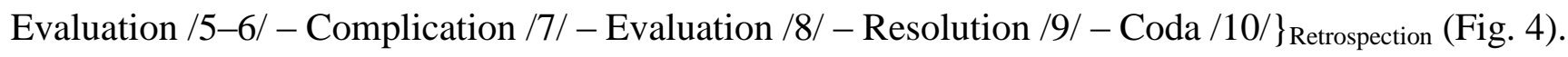




\section{Transcript}

- Orientation ( 1 ): NE-1. Newspaper information. Poirot and Hastings discuss the newspaper information about the disappearance of one million dollar bonds on board the Olympia ('Well, look at this last coup, the million dollars' worth of Liberty Bonds which the London and Scottish Bank were sending to New York, and which disappeared in such a remarkable manner on board the Olympia') [CRIME: THEFT. OBJECT: BONDS. PLACE OF CRIME: BOARD 'OLYMPIA'. WHO IS THE CRIMINAL? HOW WERE THE BONDS STOLEN? - curiosityl.

- Com p li c a tion ( 2 - 4$)$ : NE-2. Miss Esmee Farquhar's visit. The young lady asks Poirot to investigate this theft, as her fiancée, Philip Ridgeway, appeared to become the main suspect of the crime ('I am referring to the theft of Liberty Bonds on the Olympia.' $<\ldots>$ You see, Monsieur Poirot, I am engaged to Mr. Philip Ridgeway. - 'Aha! and Mr Philip Ridgeway - 'Was in charge of the bonds when they were stolen. Of course no actual blame can attach to him, it was not his fault in any way. Nevertheless, he is half distraught over the matter.. ') [ESMEE FARQUHAR: CLIENT. PHILIP RIDGEWAY: VICTIM. WHO IS THE CRIMINAL? - curiosityl. The bonds were handed to Mr. Ridgeway and sealed in his presence. On the way to New York the bonds vanished. Incredibly, but a few bonds were offered for sale before the Olympia's arrival (They were counted, enclosed in a package, and sealed in his presence, and he then locked the package at once in his portmanteau.' $<\ldots>$ 'A portmanteau with an ordinary lock?' - 'No, Mr. Shaw insisted on a special lock being fitted to it by Hubbs 's. Philip, as I say, placed the package at the bottom of the trunk. It was stolen just a few hours before reaching New York. A rigorous search of the whole ship was made, but without result. The bonds seemed literally to have vanished into thin air.' - Poirot made a grimace. 'But they did not vanish absolutely, since I gather that they were sold in small parcels within half an hour of the docking of the Olympia!') [MR. VAVASOUR: CO-VICTIM-1. MR. SHAW: COVICTIM-2. WHO IS THE CRIMINAL? HOW DID HE OPEN THE PORTMANTEAU? HOW DID HE TAKE THE BONDS AWAY? - curiosity]. NE-3. Questioning Philip Ridgeway. Poirot and Hastings meet with Mr. Ridgeway. When narrating, Philip draws the listeners` attention to a strange thing: at first the robber tried to break the lock, but then he opened the valise with a key. Poirot pricks up his ears ('My cabin trunk was half out from under the bunk and all scratched and cut about where they'd tried to force the lock.' - 'That's so. They tried to force it, but couldn't. And, in the end, they must have got it unlocked somehow or other.' - 'Curious,' said Poirot, his eyes beginning to flicker with the green light I knew so well. 'Very curious! They waste much, much time trying to prise it open, and then - sapristi! - they find that they have the key all the time -for each of Hubbs's locks are unique.' - 'That's just why they couldn't have had the key. It never left me day or night.' 'You are sure of that?' - 'I can swear to it, and besides, if they had had the key or a duplicate, why should they waste time trying to force an obviously unforceable lock!' $<\ldots>$ 'Very well, the bonds were stolen from the trunk. What did the thief do with them? How did he manage to get ashore with them?') [HOW DID THE CRIMINAL OPEN THE PORTMANTEAU? HOW DID HE TAKE THE BONDS AWAY? - curiosity]. NE-4. Questioning Mr. Vavasour and Mr. Shaw. The detective questions the bank directors and comes to know that each of them also has a key to the portmanteau. ('As to the keys, Mr. Ridgeway had one, and the other two are held by my colleague and myself') [WHO IS THE CRIMINAL: RIDGEWAY, VAVASOUR, SHAW? - curiosity]. 


\section{THE MILLION DOLLAR BOND ROBERY}

NE-1. Newspaper information.

NE-2. Miss Esmee Farquhar's visit.

NE-3. Questioning Philip Ridgeway.

NE-4. Questioning Mr. Vavasour and Mr. Schaw.

NE-5. Discussion.
NE-6. At the train.

NE-7. Questioning the stewards.

NE-8. The letter to the police.

NE-9. Reconstruction of the crime.

NE-10. Esmee Farquhar`s arrival.
A - Philip Ridgeway
B - Mr. Vavasour

C - Mr. Shaw

D - Esmee Farquhar

E - Mr. Ventnor

F - Hercule Poirot

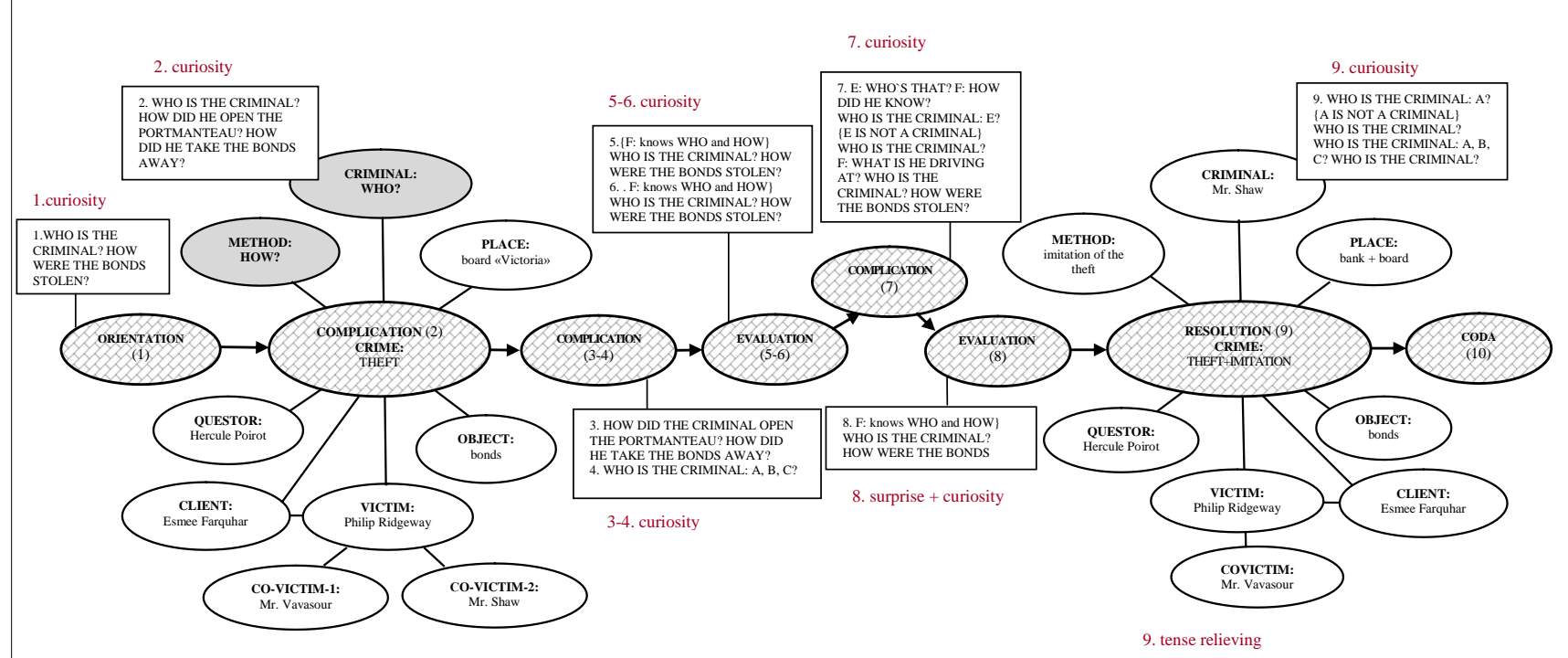

Fig. 4. 'The Million Dollar Bond Robbery': cognitive model (Retrospection) 
- E v a 1 u a t i o n ( 5-6 ) : NE-5. Discussion. On leaving the bank, Poirot declares, that he has already unraveled the case, and the only thing he needs is to question the board staff. ('I am disappointed,' said Poirot, as we emerged into the street. - 'You hoped to discover more? They are such stodgy old men.' - 'It is not their stodginess which disappoints me, mon ami. I do not expect to find in a Bank manager a "keen financier with an eagle glance" as your favorite works of fiction put it. No, I am disappointed in the case - it is too easy!' - 'Easy?' - 'Yes, do you not find it almost childishly simple?' - 'You know who stole the bonds?' - 'I do. <...>' What are you waiting for?' 'For the Olympia. She is due on her return trip from New York on Tuesday'). [POIROT: KNOWS WHO IS THE CRIMINAL AND HOW THE BONDS WERE STOLEN. WHO IS THE CRIMINAL? HOW WERE THE BONDS STOLEN? - curiosity]. NE-6. At the train. On the way to the port, Hastings tries to find out the criminal's name, but Poirot refuses to reveal his secret (Tuesday saw us speeding to Liverpool in a first-class carriage of the L.\& N.W.R. Poirot had obstinately refused to enlighten me as to his suspicions - or certainties. He contented himself with expressing surprise that I, too, was not equally au fait with the situation. I disdained to argue, and entrenched my curiosity behind a rampart of pretended indifference). [POIROT: KNOWS WHO IS THE CRIMINAL AND HOW THE BONDS WERE STOLEN. WHO IS THE CRIMINAL? HOW WERE THE BONDS STOLEN? - curiosity].

- C o m p l i c a t i o n ( 7 ): NE-7. Questioning the stewards. On Olympia board Poirot asks about one Mr. Ventnor who occupied the cabin next to that of Philip Ridgeway. This question puzzles Hastings greatly. ('An elderly gentleman, wearing glasses. A great invalid, hardly moved out of his cabin.' The description appeared to tally with one Mr. Ventnor who had occupied the cabin C 24 which was next to that of Philip Ridgeway. Although unable to see how Poirot had deduced Mr. Ventnor's existence and personal appearance, I was keenly excited') [VENTNOR: WHO'S THAT? POIROT: HOW DID HE KNOW? - curiosity]. Hastings assumes, that being that mysterious criminal, Mr. Ventnor got off the first, but the steward denies. Poirot makes a grin ('Tell me,' I cried, 'was this gentleman one of the first to land when you got to New York?' The steward shook his head. 'No, indeed, sir, he was one of the last off the boat. 'I retired crestfallen, and observed Poirot grinning at me) [WHO IS THE CRIMINAL: VENTNOR? VENTNOR IS NOT A CRIMINAL. WHO IS THE CRIMINAL? - curiosityl. Irritatingly, Hastings announces that the evidence obtained totally ruins Poirot's theory, but the detective looks completely satisfied. ('It's all very well,' I remarked heatedly, 'but that last answer must have damped your precious theory, grin as you please!' - 'As usual, you see nothing, Hastings. That last answer is, on the contrary, the coping-stone of my theory.' I flung up my hands in despair. 'I give it up') [POIROT: WHAT IS HE DRIVING AT? - surprise. WHO IS THE CRIMINAL? HOW WERE THE BONDS STOLEN? curiosity].

- E v a 1 u a t i o n ( 8 ): NE-8. The letter to the police. At the train Poirot writes a letter to the police, in which he identifies the criminal and explains the details of the crime. (When we were in the train, speeding towards London, Poirot wrote busily for a few minutes, sealing up the result in an envelope. - 'This is for the good Inspector McNeil') [POIROT: KNOWS WHO IS THE CRIMINAL AND HOW THE BONDS WERE STOLEN. WHO IS THE CRIMINAL? HOW WERE THE BONDS STOLEN? - curiosity].

- R e s o lut i o n ( 9) : NE-9. Reconstruction of the crime. At the restaurant, waiting for Esmee Farquhar, Hastings presupposes that the criminal is Philip Ridgeway, but Poirot is laughing at his friend. ('What about Ridgeway?' - 'The habit of incoherence is growing upon you, Hastings. $<\ldots>$ If Ridgeway had been the thief - which was perfectly possible - the case would have been charming; a piece of neat methodical work.') [WHO IS THE CRIMINAL: RIDGEWAY? RIDGEWAY IS NOT A CRIMINAL. WHO IS THE CRIMINAL? - curiosityl. Then Poirot 
reconstructs the crime: it was an imitation of the theft, as the bonds had been stolen much earlier. The criminal's partner arrived in New York on another board beforehand, that's why a few bonds appeared at the stock-exchange. The criminal himself was following Mr. Ridgeway, lying in hiding. Just before the arrival, he imitated the robbery and returned to London [METHOD OF CRIME: imitation]. The number of suspects is reduced to three persons who have an access to the bonds. (It would be an easy matter for any of the three men present to have prepared a duplicate package which could be substituted for the genuine one) [WHO IS THE CRIMINAL: RIDGEWAY, VAVASOUR, SHAW? - curiosity]. On hearing it, Hastings can't suppress his impatience. ('But whowhich was he?') [WHO IS THE CRIMINAL? - curiosity]. Poirot, then, deliberately drags out his answer and at last names the criminal ('The man who had a duplicate key, the man who ordered the lock, the man who has not been severely ill with bronchitis at his home in the country - enfin, that 'stodgy' old man, Mr Shaw!') [WHO IS THE CRIMINAL? - curiosity. CRIMINAL: MR. SHAW].

- C o d a ( 10$)$ : NE-10. Esmee Farquhar's arrival. Miss Farquhar enters the loungeroom. Poirot leads her to the table.

The short story 'The Million Dollar Bond Robbery' is a typical classical detective, the thematic centre of which is crime detection. In the initial macrostructure in Complication the theme CRIME is interconnected with the following argument slots: OBJECT, VICTIM, CO-VICTIM-1, CO-VICTIM-2, PLACE, QUESTOR, CLIENT, CRIMINAL (?) and METHOD (?). The latter two slots are entropic, open, i.e. lacking the necessary data, so graphically they are darkened. Since the plot movement can influence the final thematic macrostructure in Resolution, there registered some changes: the theme CRIME (theft $\rightarrow$ theft + imitation) and the slot PLACE (board $\rightarrow$ bank + board) are both modified; the slot CO-VICTIM-2 is not represented because of changing the actor B`s role (CO-VICTIM-2 $\rightarrow$ CRIMINAL), the slots CRIMINAL and METHOD are filled with relevant information, entropy is eliminated. As an emotive component of this model, curiosity, which is characteristic to Retrospection, is fixed in each narrative phase, being combined with surprise in NE-7.

According to the principles of cognitive linguistic analysis of narrative tension [Leshchenko 2017: 145-168], cognitive modeling of the story`s structure presupposes further analysis of its textual descriptions, serving as cognitive and emotional triggers of narrative tension.

\section{Conclusion}

Understanding the narrative as a result of the cognitive-emotional activity rather than as a set of different qualities of verbal texts, allows researchers to examine narrative properties, irrespectively of their individual generic and medial realizations. Therefore, cognitive modeling of the narrative structure is viewed as the method which helps to conceptualize the complicated nature of the narrative proper and to unify the principles of its analysis.

The innovative structural branch of cognitive narratology advanced in this publication, aims to relate the narrative as a linguistic macro-sign with particular mental (cognitive) structures in the speakers' minds. This methodology developed for cognitive modeling of narrative structure contributes to further exploring the field of cognitive narratology, which is new to Ukraine. The results of my research can be applied to the wide range of verbal narratives (literary and cinematic narratives, comics, audio plays etc.), as well as non-verbal narratives (music, dance, computer games etc.).

\section{REFERENCES}

Adam, J.-M. (2011). The narrative sequence: History of a concept and a research area // Colloque International 'Redefinition de la sequence dans la narratologie postclassique', May 20-21, 2011. University of Fribourg.

Admony, V. G. (1969). Sintagmaticheskoe napryazhenie $v$ stihe i proze [Syntagmatic tension in poetry and prose]. M.: Nauka (in Russian). 
Bamberg, M., Marchman, V. (1991). Binding and unfolding: Towards the linguistic construction of narrative discourse // Discourse Processes. No. 14. P. 277-305.

Baroni, R. (2006). Introduction: The many ways of dealing with sequence in contemporary narratology. In: R. Baroni, F. Revaz (eds.). Narrative Sequence in Contemporary Narratologies. Columbus: Ohio State University Press, pp. 1-11.

Bremond, C. (1973). Logique du recit. Paris: Seuil.

Brewer, W., Lichtenstein, E. (1982). Stories are to entertain: A structural-affect theory of stories. Urbana-Champaign: University of Illinois and Urbana-Champaign.

Carroll, N. (1996). The Paradox of suspense. In: P. Vorderer, H. J. Wulff, M. Friedrichsen (eds.). Suspense: conceptualizations, theoretical analyses, and empirical explorations. New YorkLondon: Routledge, pp. 71-91.

Cupchik, G.C. Suspense and disorientation: Two poles of emotionally charged literary uncertainty // In: P. Vorderer, H. J. Wulff, M. Friedrichsen (eds.). Suspense: conceptualizations, theoretical analyses, and empirical explorations. New York-London: Routledge, pp.189-197.

Dijk, T.A., van, Kintsch, W. (1983). Strategies of discourse comprehension. New York: Academic Press.

Dijk, T. A., van. (1982). Episodes as units of discourse analysis. In: D. Tannen (ed.). Analyzing discourse: text and talk. Georgetown: Georgetown University Press, pp. 177-195.

Dove, G. (1989). Suspense in the formula story. Ohio: Bowling Green State University Popular Press.

Fill, A. (2003). Linguistic Devices for the creation of suspense. In: B. Kettemann (ed.). Expanding circles, transcending disciplines, and multimodal texts. Tubingen: Gunter Narr Verlag, pp.263-276.

Fludernik, M., Olsen, G. (2011). Introduction. In: G. Olsen (ed.) Current Trends in Narratology. Berlin / New York. Walter de Gruyter, pp. 1-33.

Gerrig, R. J., Bernardo, A. (1994). Readers as problem-solvers in the experience of suspense // Poetics, No. 22, 459-472.

Grejmas, A.-Zh. (1996/2003) Razmyshleniya ob aktantnyh modelyah [Thoughts on actant models]. M.: IG Progress (in Russian).

Herman L., Vervaek B. (2009). Narrative interest as cultural negotiation // Narrative, Vol. 17, Number 1, 111-129.

Herman, D. (2009). Story logic: problems and possibilities of narrative. Lincoln, NE: University of Nebraska Press.

Kintsch, W. (1998 / 2004). Comprehension: A paradigm for cognition. Cambridge: Cambridge University Press.

Kuijpers, M. (2014). Absorbing stories. The effects of textual devices on absorption and evaluative response. Utrecht: Utrecht University.

Labov, W. (1972). The transformation of experience in narrative syntax. In: Language in the inner city: Studies in the Black English Vernacular. Philadelphia: U. Pennsylvania Press, pp. 354-396.

Labov, W., Waletzky, J. (1967). Narrative analysis: oral versions of personal experience. In: J. Helm (ed.). Essays on the Verbal and Visual Arts. Seattle: University of Washington Press, pp. 12-44.

Larivaille, P. (1974). L`analyse (morpho)logique du récit // Poétique, No.19, 368-388.

Leshchenko, A. V. (2017). Narrativnaya napryazhennost' hudozhestvennogo teksta [Narrative tension in the literary text]. Cherkassy: CHP Gordienko E. I. (in Russian).

Myshkina, N. L. (1998). Vnutrennyaya zhizn' teksta: mekhanizmy, formy, harakteristiki [The inner life of the text: mechanisms, forms, characteristics]. Perm': Izdatel'stvo Permskogo universiteta (in Russian). 
Phelan, J. (2006). Narrative theory, 1966-2006: A Narrative. In: R. Scholes, J. Phelan, R. Kellogg (eds.). The Nature of narrative: revised and expanded. Oxford: Oxford University Press, pp. 295-328.

Propp, V. Y. (1928 / 2001). Morfologiya volshebnoj skazki [Morphology of the fairy-tale]. M.: Labirint (in Russian).

Reichl, S. (2009). Cognitive principles, critical practice: Reading literature at university. Vienna: Vienna University Press.

Ryan, M.-L. (2005). Media and narrative. In: D. Herman, M. Jahn, M.-L. Ryan Routledge Encyclopedia of Narrative Theory. London: Routledge.

Scott, J. (2013). Creative writing and stylistics: creative and critical approaches. L.: Palgrave Macmillan.

Stern, I. B. (1998).Vibrani topiki ta leksikon suchasnoï lingvistiki: entsiklop. slovnik dlya fakhivtsiv z teoretichnikh gumanitarnikh distsiplin ta gumanitarnoï informatiki. K.: «ArtEk» (in Russian).

Sternberg, M. (2003). Universals of narrative and their cognitive fortunes (II) // Poetics today, $24: 3,517-638$.

Sternberg, M. (2003). Universals of narrative and their cognitive fortunes (I) // Poetics today, 24:2, 297-395.

Tan, E. (1996). Emotion and the structure of narrative film: Film as an emotion machine. NJ: Mahwah.

Todorov, Tz. (1981). Introduction to Poetics, trans. Richard Howard, introduction by Peter Brooks, Minesota U. P. [Translation of: Poétique, Paris, Seuil 1968 \& 1973].

Vorobyova, O. P. (2013). Lingvistika segodnya: reinterpretatsiya epistemy // Visnik KNLU. Seriya: Filologiya, t. 16, 2, 41-47. (in Russian).

Wulff, H. J. (1996). Suspense and the influence of cataphora on viewer's expectations. In: P. Vorderer, H. J. Wulff, M. Friedrichsen (eds.). Suspense: conceptualizations, theoretical analyses, and empirical explorations. New York-London: Routledge, pp.1-17.

Yeltsova, M. N. (2006). Kategorii napryazheniya i napryazhennosti prostogo povestvovatel'nogo predlozheniya [Categories of tension and tenseness in the simple affirmative sentence]. Perm': Permskij tekhnicheskij universitet. (in Russian).

Yudina, T. V. (1990). Kategoriya napryazhennosti i sredstva ee vyrazheniya [Category of tension and the means of its manifestation]. Leningrad: Leningradsky gosudarstvennyj pedagogicheskij institut im. A. I. Gercena. (in Russian).

Zhabotinskaya, S. A. (2013). Semantika lingval'nyh setej $i$ strukturirovanie informacii $v$ professional'noj sfere: materialy konferencii [Semantics of lingual networks and information structuring in the professional sphere: conference papers]. SPb: Izd-vo IMC «NVSH-SPb» (in Russian).

Zillman, D. (1996). The psychology of suspense in dramatic exposition. In: P. Vorderer, H. J. Wulff, M. Friedrichsen (eds.). Suspense: conceptualizations, theoretical analyses, and empirical explorations. New York-London: Routledge, pp.199-231.

\section{DATA SOURCES}

Christie, A. (1924) The Million Dollar Bond Robbery. In: A. Christie. Poirot Investigates. 2018. URL: http://www.globaltradewatch.org/Poirot-Investigates-Hercule-Collection

Hanna Leshchenko - Phd in Linguistics, Professor of Department of Applied Linguistics, Cherkasy State Technological University (Shevchenka Blvd., 460, Cherkasy, 18006, Ukraine); e-mail: anles_ua@ukr.net; ORCID: https://orcid.org/0000-0002-5316-0628 
Ганна Лещенко - кандидат філологічних наук, доцент, профессор кафедри прикладної лінгвістики Черкаського державного технологічного університету (бул. Шевченка, 460, Черкаси, 18006, Україна); e-mail: anles_ua@ukr.net; ORCID: https://orcid.org/0000-0002-53160628

Анна Лещенко - кандидат филологических наук, доцент, профессор кафедры прикладной лингвистики Черкасского государственного технологического университета (бул. Шевченко, 460, Черкассы, 18006, Украина); e-mail: anles_ua@ukr.net; ORCID: https://orcid.org/0000-00025316-0628 


\section{TRANSLATION AS A MEANS OF CONSTRUCTING CULTURES: PHILOSOPHICAL FOREGROUNDING O.V. Rebrii (Kharkiv, Ukraine)}

O.V. Rebrii. Translation as a means of constructing cultures: philosophical foregrounding. The aim of the article is to portray translation as a means of constructing cultures in terms of philosophy. Proceeding from the idea that cultural enrichment occurs due to the translation of not only literary works, but also ideas, traditions, way of living, etc., the hypothesis was put forward that philosophical description and analysis of translation should be carried out on the basis of two interwoven phenomena - culture and creativeness. Methodology of the article is determined by general humanitarian principles of interdisciplinarity (use of methods and theories of such correlated disciplines as cultural studies, translation studies, philosophy), anthropocentrism (emphasis on the agent of action as a focal point of translation process), and poliparadigmatism (combination of provisions of classical structural and modern cognitive paradigms resulting in the complex character of the research). Scientific novelty of the research is determined by obtaining some new information concerning the role of translation as a means of (self)cognition / (self)reflection; individual and collective development; and shaping cultural continuum. Innovative approach to translation allows to come to a more profound philosophical understanding of this phenomenon going beyond its linguistic and/or communicative essence and to appreciate its significance for creative self-improvement of all the involved individuals (author, translator, and recipient) as well as for sustained cultural growth all over the world. Conclusions. Conducted research revealed global creative function of translation that helps establish and develop cultures on a universal scale since the majority of national cultures were constructed in the process and under the influence of translation. In the context of Ukrainian colonial and post-colonial history, the article highlighted the role of translation as a cultural catalyst, transmitter of ideas, and defender of spiritual values.

Key words: cognition, creativeness, culture, development, nation, philosophy, reflection, translation.

О.В. Ребрій. Переклад як засіб культуротворення: філософське обгрунтування. Мета статті полягає у тому, аби представити переклад як засіб культуротворення у термінах філософії. Виходячи 3 тези, що культурне збагачення здійснюється за рахунок перекладу не тільки художньої літератури, а й ідей, традицій, способу життя тощо, було висунуто гіпотезу про те, що філософський опис та аналіз перекладу має здійснюватися на основі двох переплетених феноменів - культури та креативності. Методологія статті визначається загальними гуманітарними принципами міждисциплінарності (використання методів й теорій таких суміжних дисциплін, як культурологія, перекладознавство, філософія), антропоцентризму (наголос на агенті дії як фокальній точці перекладацького процесу) та поліпарадигматизму (поєднання положень класичної структурної та модерної когнітивної парадигм, що зумовлює комплексний характер дослідження). Наукова новизна дослідження визначається отриманням нової інформації щодо ролі перекладу як засобу (само)пізнання, (само)рефлексії, індивідуального й колективного розвитку та формування культурного континууму. Інноваційний підхід до перекладу дозволяє здійснити глибше філософське осмислення цього феномену, що виходить за межі його лінгвістичної та/або комунікативної сутності, та оцінити його значущість для творчого самовдосконалення усіх залучених особистостей (автора, перекладача, реципієнта) так само як і для усталеного культурного розвитку у світі. Висновки. Проведене дослідження висвітлюе глобальну креативну функцію перекладу, який допомагає засновувати та розвивати культури у світовому масштабі, адже більшість національних культур сформовано у перебігу та під впливом перекладу. У контексті 
української колоніальної та постколоніальної історичної ситуації стаття підкреслює роль перекладу як культурного каталізатора, провідника ідей та хоронителя духовних цінностей.

Ключові слова: культура, нація, переклад, пізнання, рефлексія, розвиток, творчість, філософія.

А.В. Ребрий. Перевод как средство культурообразования: философское обоснование. Цель статьи заключается в том, чтобы представить перевод как средство культурообразования в понятиях философии. Исходя из того, что культурное обогащение осуществляется за счет перевода не только художественной литературы, но и идей, традиций, способа жизни и пр., была выдвинута гипотеза о том, что философское описание и анализ перевода следует осуществлять на основе двух переплетенных феноменов - культуры и креативности. Методология статьи определяется общими гуманитарными принципами междисциплинарности (использование методов и теорий таких смежных дисциплин, как культурология, переводоведение, философия), антропоцентризма (выделение роли агента деятельности как фокальной точки переводческого процесса) и полипарадигматизма (объединение положений классической структурной и современной когнитивной парадигм, которое определяет комплексный характер исследования). Научная новизна исследования заключается в получении новой информации о роли перевода как средства (само)познания, (само)рефлексии, индивидуального и коллективного развития и формирования культурного континуума. Инновационный подход к переводу позволяет осуществить глубинное философское осмысление этого феномена, которое выходит за рамки его лингвистической и/или коммуникативной сущности, а также оценить его значимость для творческого самоусовершенствования всех задействованных личностей (автора, переводчика, реципиента) и устойчивого культурного развития во всем мире. Выводы. Проведенное исследование раскрывает глобальную креативную функцию перевода, который помогает основывать и развивать культуры во всемирном масштабе, поскольку большинство национальных культур сформировались в процессе и под влиянием перевода. В контексте украинской колониальной и постколониальной исторической ситуации статья подчеркивает роль перевода как культурного катализатора, проводника идей и хранителя духовных ценностей.

Ключевые слова: культура, нация, перевод, познание, развитие, рефлексия, творчество, философия.

\section{Introduction}

So far, philosophical interpretation of the phenomenon of translation has remained rather limited, confining itself to some aspects of philosophical hermeneutics, theory of knowledge / reflection (epistemology), or philosophy of communication, all of which deal with material primarily derived from psychology, psycholinguistics, semiotics, cultural studies and only then from translation studies. At the same time, philosophy can develop its own theory of translation, not only relatively independent of the abovementioned approaches but also capable of providing additional insight for their further development. Such a theory aims at a more profound philosophical understanding of translation going beyond its linguistic and/or communicative essence, which determines the relevance of this research.

\section{General overview of the problem}

How relevant is the introduction of the notion of translation into the paradigm of modern philosophy? The advantages of this are evident as the look at translation as one of the premises of thinking, as a universal mediator in human life and culture allows to see new facets in philosophy as a form of cognition and knowledge embodiment. Thus, the problem of translation takes a new philosophical turn, though philosophers were quite reluctant to admit that philosophy is literally unthinkable without the idea of translation or rather translatability which "forms an elementary ingredient of cognition act" and that "the ontology of translation forms the first and utmost condition of transferring non-verbal content of the mind into articulated, grammatical, and discursive forms" [Fokin 2011: 164].

Meanwhile, this conclusion as to translation's philosophical load is not something principally new for the scholars in the field of translation studies who are well aware of R. Jakobson's typology 
of translations according to which hand in hand with interlinguistic (proper) translation there exist intralinguistic (rewording) and intersemiotic (transmutation) ones [Jakobson 1959: 233]. Global ontological status of translation is getting even more evident if we add to this typology "the transference of the unconscious... into critical or transformed forms of consciousness" [Fokin 2011: 164]. N. Galeeva adds that "the translation of one culture into another is also an important form of translation that is not always perceived and described" as it "doesn't fit into linguistic theory" [Galeeva 2006: 25].

Taking into account the potential diversity of translation's philosophical and cultural implications, we put forward the hypothesis that describing and analyzing translation in terms of philosophy should be done proceeding from two interwoven phenomena - culture and creativeness simply because, as N. Avtonomova points out, "all European philosophies... appeared in the process of translating from one language into another, from one culture into another and creative activity connected with it" [Avtonomova 2008: 7]. Obviously, "to appear in the process of translating" does not mean "to appear only from borrowed words and concepts", but "in order for a philosophy to appear, in addition to certain social circumstances such elements as internal impulse, inclination, mind orientation, and intensive work of transforming the foreign into the native are needed" [ibid.]. Thus, the a i m of this article is to portray translation as a creative (inter)cultural phenomenon.

Philosophical approach to creativeness, firstly, gives impetus to its further elaboration within other disciplines and sciences; secondly, helps determine general scientific outlines and priorities of its investigation; and thirdly, has a considerable scientific potential per se. Symbolically, in the context of H. Skovoroda's philosophical doctrine, translation is described as "a congenial labour", that is as a joint creativeness of the representatives of different cultures united by common aesthetic values [Bevz 2011].

Today, the category of creativeness gains a key status not only in comprehending the dynamics of social-historical processes, and prospects of individual growth, but also in "grasping the organization of the universe, the unbreakable bond of its creative potential with innovative activities of human beings" [Yakovlev 2003: 142]. The main philosophical issue in studying creativeness is exposing its ontological status, which immediately brings to mind the statement about translation lying at the core of philosophy evolution itself. There's no doubt that translation is in the first place a linguistic phenomenon, but to lock it in the realm of semasiology stripping of other investigative alternatives means to simplify and impoverish it, to rob of that creative potential due to which modern cultural and humanitarian paradigms are being constantly shaped and reshaped.

Thus, translation appears before us not only as a mediator in interlinguistic exchange of information, but also as a precondition of any social and humanitarian knowledge. Typically, specialists in the field of translation studies emphasize translation's creative nature in connection with the development of national languages and literatures, expansion of the range of genres and stylistic devices, but philosophical accent on translation is quite different; it is aimed at exposing triple role of this phenomenon - as a means of (self)cognition / (self)reflection, as a means of individual and collective development, and as a means of shaping cultural continuum. Highlighting these three roles sets the tasks of our research.

\subsection{Translation as a creative instrument of (self)cognition / (self)reflection}

Today, translation is generally recognized as "an anthropological constant of human existence" as well as "an influential factor of cognition" [Ryabova]. This acclaim was won when translation transformed from a specialized technical area ("craftsmanship") into the sphere of "roaring passions" and "clashes" of scholars who tried to solve such practically unsolvable dilemmas as translatability / nontranslatability, foreignization / domestication, preciseness / impreciseness, etc. Cognition through translation is of creative nature since it proceeds from the human ability "to form the torrents of innovations that provide grounds for qualitative breakthroughs in culture and 
guarantee the evolution of both a man and a society" [ibid.]. And yet, in a philosophical sense the combination of "cognition" and "translation" is somewhat unusual. Cognition is most often studied as a mental activity or as a social institution while translation is typically perceived as a linguistic and/or cultural phenomenon. Establishing ties between cognition and translation (cognition as translation and translation as cognition) allows to focus the attention on different important issues of humanitarian knowledge and to turn translation studies into a truly interdisciplinary field.

Cognitive function of translation is not limited by its role of an intercultural mediator. The role of an intellectual stimulator, defined by $\mathrm{Yu}$. Sorokin as "translation from essence into essence" [Sorokin 2005: 46], is of no lesser importance. Translation inevitably involves intuition, art, individuality. But all these important aspects are subordinate to cognition; thus, translation should be treated as a form of cognition which transforms non-verbal experience into verbal forms and launches reflective mechanism of exploring human mind and communication. By following this path, we switch from perceiving translation as a universal instrument of cognition to perceiving translation as a means of cognition by the subject of thought of himself/herself, i.e. to perceiving translation as (self)reflection.

In modern translation studies, reflection is considered a powerful methodological tool which helps in the research of translation process by introducing the figure of the translator as an agent of action who carefully monitors gradual unfolding of one thought after another and fixates the logic of his/her decisions. In this sense, reflection can be defined as a search for sense construed on the appeal of the translator's consciousness to that of the author. Meanwhile, philosophical notion of translation as a reflection is principally different proceeding from the idea of transferring external experience into internal one and vice versa. In a philosophical sense, reflection appears an obligatory way of human existence which philosophical comprehension of life is connected with.

In P. Ricoeur's philosophical concept, the notion of reflection is connected with hermeneutics - the teaching about the art of interpretation. The essence of translation is described by the author as interpretation, as the best way to "explain one thing through another" [Riker 2002: 45]. Reflection, in its turn, is the way to comprehend translation, i.e. to interpret the interpreted. Reflection is "a bridge between understanding signs and human self-understanding", and "only through self-understanding we get a chance to comprehend the existence itself". Such is the way by which reflection "re-integrates semantics into ontology" [ibid: 48]. Any translation is primarily interpretation, and any interpretation "aims at overcoming the distance between the previous cultural period, which the text belongs to, and the interpreter. By doing that, by becoming the text's contemporary, the interpreter can appropriate its meaning, make it his own and consequently expand his own self-understanding through understanding another" [ibid.]. That is how translation becomes hermeneutics and hermeneutics is understanding of oneself, i.e. reflection. Thus, in their mutual relations translation, cognition (interpretation), and reflection present a particular case of Ricoeur's hermeneutic circle.

\subsection{Translation as a source of individual and collective development}

It is no secret that translation is a form of an individual's self-development, because while interpreting from one language into another in more and more complex social circumstances a person evolves intellectually. O. Polishchuk points at the dual role of creativeness in the process of cognition which is equally characteristic of translation. She describes creativeness as a special form of human activity which results in the emergence of new material and spiritual values. It has both social-cultural and personal meaning, since it serves as a way of an individual's self-realization due to which "new horizons of spiritual life are opened and comprehended" [Polishchuk 2007: 153]. Translation is not just a substitution of words from one language by words from another language. It is a powerful incentive to intellectual growth. By mastering a new language, the translator simultaneously masters its culture and this bilateral process leads, firstly, to individual changes; and secondly, through numerous individual changes to mass social ones. Consequently, cultural 
potential of an individual is increasing which in its turn stimulates cultural evolution of each society and humankind in general.

Throughout their history, people have been elaborating and complicating their world which resulted in human activity gaining more potential as well as in increasing its ability to expand both theoretically and practically and to deepen penetration into reality that yet remained unassimilated and unknown. One of the forms of human reaction towards complicated social practices is intensification of communication under which we understand "ever increasing, both in scale and speed, changes in the character and contents of communication among the representatives of different languages and cultures" [Ryabova 2008: 167]. In the context of global social changes, people more and more often get in contact with representatives of other cultures. In connection with this, translation acquires a new role - it acts as a means of solving the problem of otherlanguageness.

Otherlanguageness is a social-cultural and social-philosophical phenomenon that appears "as a result of intensification of a dialogical activity on the border between languages" [Akhiezer and Ryabova 2005: 142] and serves as a powerful source of social diversity, including the diversity of a person's creative development. It's incorrect to reduce the concept of otherlanguageness to borrowing elements from one language to another. It should also be considered in relation to the evolution and elaboration of every language in the process of mutual penetration. Hence, the necessity of theoretical foregrounding of the category of "translation-interpretation" as "a flow of new meanings obtained through interpretation" [ibid.]. The category of translation-interpretation makes the concept of otherlanguageness more profound since it takes the form of an intellectual evolution of an individual who's searching for principally new ways to cope with the problem of intercultural diversity. An individual's increasing cultural potential gives an impetus to further implementation of his/her creative potential, formation of new relations both inside a particular culture and among the representatives of different cultures. Otherlanguageness is of a dual axiological nature. Its negative aspect is revealed through juxtaposition / opposition of different groups of people based on a linguistic criterion due to which conflicts caused by misunderstanding, communicative failures, or inability to sustain a dialogue may emerge. Its positive aspect is revealed through opening an access to cultural treasures of other countries and nations, as well as through obtaining a possibility for building up an individual's creative qualities. Positive potential of otherlanguageness is realized in people's creative evolution stemming from "stimulating the growth of their abilities to solve more and more complex tasks" [Ryabova 2008: 170]. It becomes possible "as a result of people's orientation towards positive implications of increasing diversity" [ibid.].

The meaning of translation as a means of self-improvement can hardly be overestimated. Starting from its positive impact on the development of memory, intellect, imagination, articulation, rhetoric, communicative skills, etc., and finishing with the perspective of getting beyond the magic circle of the mother-tongue, translation gives people an opportunity to evolve creatively and to reach new professional and individual achievements. That's how a dialectical dependence between the translator's level of professionalism (competence) and his ability to work with the texts of the highest complexity is established.

Inquiring into the in-depth mechanisms of translation, P. Ricoeur asks a question: "What is the translator's motivation?" And gives the answer: "Desiring translation". Pure wish as an aesthetic and psychological category has quite materialistic cultural consequences, because the translator, in addition to aesthetic satisfaction, self-improving, and self-educating, "can also 'open' his/her native language and its resources anew" [Riker 2002: 298]. In this respect, Ukrainian classic M. Rylsky has a wonderful allegory which likens the translator to the hunter: "When the hunter comes to a meadow or to a marsh rich with game he is enveloped by a merry expectation of a happy hunting. At the same time, he strains all his strength to make the hunting successful. For this, he must show his knowledge of birds' habits and they are quite different: snipe has its own, great snipe - its own; duck's habits are quite peculiar. The hunter must also take into consideration the relief, wind 
direction, etc.; finally, he's expected to demonstrate his shooting skills! Something like this can be said about a literary translator who begins his work with a piece of fiction. Here's his faith in future accomplishments, and acknowledgment of considerable hardships, and mobilization of all his knowledge, experience, technical devices which are to be employed differently every time depending upon the author's individuality" [Rylskyi 1975: 79].

Summing up: translation doesn't only stand as a source of creative self-improvement of all the involved individuals, but also forms a strong foundation for sustained cultural growth all over the world due to the attraction of more people to its orbit. With this statement, we move on to the final task of our research.

\subsection{Translation as an important element of forming cultural continuum}

Global science has finally acknowledged translation's huge role in the creation of national and international cultural spaces. Translation unites countries, nations, and cultures on both synchronic (in a geographical plane) and diachronic (on a time scale) levels. In the aspect of (inter)cultural cooperation, we would like to accentuate the creative nature of translation because the term "creativeness" itself implies both an individual's activity and produced by him/her values, which gradually transform from the facts of one's personal life into those of culture. Translation doesn't only shape separate national cultures, it also allows to grasp the unity of the world culture as a testimony of humankind's consolidation at the dawn of the third millennium. In the process of studying multifaceted intercultural ties, the readiness of a particular national culture to perceive and process everything new in the area of linguistic and literary creativeness should be confirmed by the level of its involvement into the world's translation practices. That is why, among numerous functions of translation as a social universal, its role of the facilitator of interlinguistic, interliterary, and, finally, intercultural dialogue occupies a place of honour.

N. Bevz considers translation "a necessary link in the assimilation of international thought by Ukrainian culture and all intellectual community" since the majority of outstanding philosophers of the past and present revealed themselves only "when started to talk Ukrainian" [Bevz 2011: 38]. Relation between translation and society's cultural evolution is reciprocal: on the one hand, translations into Ukrainian assist in the further construing of the Ukrainian language; on the other hand, "translation requires its own language" as the translator "works in accordance with the ideas of the author whose text he's dealing with" [Horskyi 2001: 57].

Most cultures have been formed with the participation and under the influence of translation and following transference on a new cultural ground of genres, motives, plots, traditions, and the way of living in general. All these factors provide for the culture-shaping function of translation. As A. Lefevere puts it, "mainly translations, deeply affect the interpenetration of literary systems, not just by projecting the image of one writer or [his] work in another literature... but also by introducing new devices into the inventory component of a poetics and paving the way to changes in its functional component" [Lefevere 1992: 38]. At the same time, the translator's work today is affected by the fact that due to the intensification of cultural exchanges the languages simply do not have enough time and strength to renovate one another.

In the context of dividing cultures translation-wise into "primary" (whose construction relied largely on translation) and "secondary" (whose construction was not largely influenced by translation), we should stress that since Kievan Rus translated literature has been playing an extremely important role in Ukraine's cultural life as a protector of spiritual values, as an educational tool, and as a means of self-expression and enrichment of the native language and literature. Thus, translation became a historical event supporting the coexistence of Ukrainian culture with those of different nations.

Another side of translation is connected with overcoming cultural barriers which, according to S. Ter-Minasova, are far more dangerous than linguistic ones because "they are hidden behind the curtain of confidence that one's own culture is the only possible, correct, and normative (simply normal) one; and realization of these barriers only takes place in people's communication during the 
conflict between one's own and foreign cultures" [Ter-Minasova 2008: 68]. This statement contains a precondition for the translator's professional improvement, because any kind of a conflict is always a source of evolution. Overcoming cultural barriers is possible with the help of the principle of cultural relativism according to which an individual's behaviour (including speech) can only be evaluated within his/her culture and never from the position of the evaluator's culture whose standards may find such a behaviour nonsensical or even barbaric.

Cultural-philosophic meaning of translation is supported by the fact that it can be used as a means of bonding every time where a threat of a cultural split or collision appears. Translation provides a foundation for uniting different nations on a joint cultural platform in a sort of a cultural synthesis - "an immanent process of culture, language, skills, ability to generalize new sense emerging from creative human search" [Ryabova 2008: 173]. Synthesizing cultural diversity is an eternal problem of human civilization while its absence can pose a permanent threat to it.

Finally, translation's creative role can be analyzed from the standpoint of V. Bibler's "concept of dialogism" which describes the dialogue of different cultures as "a continuous unfolding and construing of new meanings of each cultural phenomenon, cultural image, cultural piece of work that join in a single dialogue, that is unfolding and construing a personality... capable of deepening, developing, re-shaping his/her inner self, his/her unique being in response to the addressee's (reader's, listener's, observer's) accord or discord" [Bibler 1991]. Intercultural dialogue conducted by the means of translation presents an opposition "own culture - foreign culture" which can be described as mutual attraction and mutual repulsion of opposite cultural poles. Such a dualism of translation is necessary for constructing cultural continuum as a new meaning, new creativeness, and new stage of human evolution.

\section{Conclusion}

In our research, we attempted to analyze global creative function of translation that helps establish and develop culture on a universal scale since the majority of national cultures were constructed under the influence of translation. In the context of Ukraine's historical and contemporary (postcolonial) realia, it is translated literature that plays a role of a cultural catalyst, transmitter of ideas, and defender of spiritual values on both synchronic (from language and/or culture to language and/or culture) and diachronic (from period to period) levels. The prospect of further research lies in the elaboration of the philosophical theory of translation.

\section{REFERENCES}

Akhiezer, A.S., and Ryabova, M.E. (2005). Social'naja filosofija v uslozhnjajushhemsja mire [Social philosophy in a more complex world]. Obshhestvennye nauki i sovremennost'. - Social sciences and modern life, 3, 137-143 (in Russian)

Avtonomova, N.S. (2008). Poznanie i perevod. Opyty filosofii jazyka [Cognition and translation. Philosophical experience of the language]. Moscow: Rossiyskaya politicheskaya entsiklopediya Publ.

Bevz, N.V. (2011). Pereklad filosofskykh tekstiv u suchasnomu kulturnomu prostori Ukrainy [Translation of philosophical texts in Ukraine's modern cultural environment]. Visnyk Zhytomyrskoho derzhavnoho universytetu imeni Ivana Franka. Ser.: Filolohichni nauky. Herald of Ivan Franko Zhytomyr State University. Series: Philology, 56, 38-41 (in Ukrainian)

Bibler, V.S. (1991). Ot naukouchenija - $k$ logike kul'tury (Dva filosofskih vvedenija v dvadcat' pervyj vek) [From the doctrine of science to cultural logic (Two philosophical introductions to the XXI century)]. Moscow: Izd-vo politicheskoy literatury. Available at: http://www.philosophy.ru/library/bibl/bibler.html.

Fokin, S.L. (2011). Perevod kak nezadacha russkoj filosofii: $\mathrm{k}$ kritike koncepcii mimesisa V.A. Podorogi [Translation as a Russian philosophy's bad luck: To the criticism of V.A. Podoroga's 
concept of mimesis]. Politicheskaja konceptologija. - Political conceptology, 1, 162-177. Available at: http://politconcept.sfedu.ru/2011.1/11.pdf (in Russian)

Galeeva, N.L. (2006). Perevod v kul'ture: utochnenie statusa i ponjatij [Translation in culture: defining the status and notions]. Kritika i semiotika. - Critics and Semiotics, 9, 24-35 (in Russian)

Horskyi, V.S. (2001). Pereklad yak interpretatsiia po-ukrainsky [Translation as interpretation in Ukrainian]. In V.S. Horskyi (ed.). Filosofiia v ukrainskii kulturi: metodolohiia ta istoriia. Filosofski narysy [Philosophy in Ukrainian culture: methodology and history. Philosophical essays]. Kyiv: Tsentr praktychnoi filosofii Publ., pp. 54-61

Jakobson, R. On linguistic aspects of translation. Available at: https://www.academia.edu/ 26570349/Jakobson_Roman_1959_On_Linguistic_Aspects_of_Translation.

Lefevere, A. (1992). Translation, Rewriting and the Manipulation of Literary Fame. L., N.Y.: Routledge

Polishchuk, O.P. (2007). Khudozhnie myslennia: estetyko-kulturolohichnyi dyskurs: monohrafiia [Artistic thinking: aesthetic-cultural discourse: monograph]. Kyiv: Vyd. PARAPAN Publ.

Riker, P. (2002). Konflikt interpretacij. Ocherki o germenevtike [The conflict of interpretations. Essays in hermeneutics]. Moscow: "KANON-press-Ts"; "Kuchkovo pole" Publ.

Ryabova, M.E. (2008). Inojazychie kak faktor razvitija lichnosti i obshhestva [Otherlanguageness as a factor of individual and social development]. Obshhestvennye nauki i sovremennost'. Social sciences and modernity, 2, 167-176 (in Russian)

Ryabova, M.E. Filosofskie osnovy perevoda [Philosophical foundations of translation]. Available at: http://study-english.info/article033.php

Rylskyi, M. (1975). Mystetstvo perekladu [The art of translation]. Kyiv: Radianskyi pysmennyk Publ.

Sorokin, Yu.A. (2005). Chto my delaem, kogda perevodim hudozhestvennyj tekst [What we do when we translate a literary text]. Voprosy kognitivnoj lingvistiki. - Problems of cognitive linguistics, 1, 44-48 (in Russian)

Ter-Minasova, S.G. (2008). Vojna i mir jazykov $i$ kul'tur [War and peace of languages and cultures]. Moscow: Slovo Publ.

Yakovlev, V.A. (2003). Filosofija tvorchestva v dialogah Platona [Philosophy of creativeness in Plato's dialogues]. Voprosy filosofii. - Problems of philosophy, 6, 142-154 (in Russian)

Oleksandr Rebrii - Professor, Head of Mykola Lukash Translation Studies Department, Vasyl Karazin Kharkiv National University, 4, Maidan Svobody, room 7-76, Kharkiv; email: rebriy@vega.com.ua; ORCID http://orcid.org/0000-0002-4912-7489; Google Scholar https://scholar. google. com/citations?user=ak5-nc8AAAAJ\&hl=en

Олександр Володимирович Ребрій - доктор філологічних наук, професор, завідувач кафедри перекладознавства імені Миколи Лукаша ХНУ імені В.Н. Каразіна. Майдан Свободы, 4, к. 7-76. м. Харків; email: rebriy@ vega.com.ua; ORCID http://orcid.org/0000-0002-4912-7489; Google Scholar https://scholar. google. com/citations?user=ak5-nc8AAAAJ\&hl=en

Александр Владимирович Ребрий - доктор филологических наук, профессор, заведующий кафедрой переводоведения имени Мыколы Лукаша ХНУ имени В.Н. Каразина. Площадь Свободы, 4, к. 7-76. г. Харьков; email: rebriy@vega.com.ua; ORCID http://orcid.org/0000-00024912-7489; Google Scholar https://scholar. google. com/citations?user=ak5-nc8AAAAJ\&hl=en 


\section{MODELS OF NARRATION IN LITERARY TEXSTS For CHILDREN (Case study of Norman Lindsay's fairy tale "The Magic Pudding") A.O. Tsapiv (Kherson, Ukraine)}

A.O. Tsapiv. Models of narration in literary texts for children (case study of Norman Lindsay's fairy tale "The Magic Pudding"). The research focuses on reconstruction of the model of narration "Merrygo-round" in Norman Lindsay's fairy tale "The Magic Pudding" and revealing lexical, grammatical, semiotic means of its actualization in the text. It is believed that narration refers to the concrete and directly visible way in which a story is told, comprising word choice, sentence length and narrating agent. The model of narration is realized as a cognitive and linguistic construal which we represent as an abstract schema. The model of narration "Merry-go-round" is inbuilt into the narrative structure of the text. The semantics of the name of the model taken from different thesaurus sources: etymological, synonymous and definitional correlates with the name of the game and enables us to reveal typical features of the word and main characteristics of the game itself: it is something pleasant and funny for children, it moves round, has circular movements. Circular fast movements of merry-go-round correlate to the description of its movements in narrative situations in the fairy tale i.e. the repetition of adventures of main characters. On lexicogrammatical level circular movement is actualized via motion verbs. Text illustrations of the fairy tale serve as semiotic means of realization funny circular movements. It is claimed that such narrative structure of the text subconsciously activates in a child's mind his/her knowledge, memories, emotions connected with the play Merry-go-round and as a result makes a child get interested in a fairy tale and keeps him/her engaged in the development of the plot.

Key words: model of narration, fairy tale, narrative structure, narrative situation, plot.

А.О. Цапів Моделі нарації у художніх текстах для дітей (на матеріалі казки Нормана Ліндсі «Чарівний пудинг»). Статтю присвячено реконструюванню моделі нарації «Merry-go-round» («Карусель») у казці Нормана Ліндсі «Чарівний пудинг» та виявленню лексичних, граматичних і семіотичних засобів іiі реалізації у художньому тексті. У дослідженні нарацію розуміємо як конкретний спосіб повістування історії, який охоплює лексичні, синтаксичні, наративні (наратор та нарататор) особливості художнього тексту. Модель нарації витлумачено як лінгвокогнітивний конструкт, який ми представляємо у вигляді абстрактної схеми. Модель нарації «Merry-go-round» є вписаною у наративну структуру художнього тексту. Семантика імені моделі нарації співвідноситься з іменем гри. Етимологічних розвідки та вивчення семантики у тлумачних та синонімічних словниках уможливлюють виявлення найтиповіших ознак та характеристик імені моделі та самої гри. «Merry-go-round» - це приємна та смішна дитяча гра-розвага, із швидким обертом по кому. Семантика циклічного руху реалізована у наративних ситуаціях - пригоди головних персонажів повторюються по колу. На лексичному та граматичному рівнях семантика рух відбита у дієсловах із значенням руху. На семіотичному рівні семантики руху втілена в ілюстраціях, які візуально нагадують оберт по колу. Така наративна структура художнього тексту підсвідомо активує в уяві дитини іiі знання, спогади, емоції, пов'язані із грою-розвагою merry-go-round, що збуджує дитячу допитливість і сприяє її зацікавленості у розвитку сюжету казки.

Ключові слова: модель нарації, казка, наративна структура, наративна ситуація, сюжет.

А.О. Цапив. Модели наррации в художественных текстах для детей (на материале сказки Нормана Линдси «Волшебный пудинг»). Статья посвящена реконструкции и описанию модели наррации «Merry-go-round» («Карусель») в сказке Нормана Линдси «Волшебный пудинг» и выявлению лексических, грамматических и семиотических особенностей ее реализации в тексте.

(C) Tsapiv A.O., 2018 
В исследовании наррацию понимаем как конкретный способ повествования истории. Наррация предполагает особый выбор лексических, грамматических и семиотических средств, использованных в художественном тексте. Модель наррации понимаем как лингвокогнитивный конструкт, который представляем в виде абстрактной схемы. Модель наррации «Merry-go-round» («Карусель») вписана в нарративную структуру художественного текста. Семантика имени модели наррации соотносится с именем игры. Изучение семантики в этимологических, толковых и синонимических словарях позволяет выяснить типичные признаки и характеристики имени модели, а также самой игры в целом. «Merry-go-round» («Карусель») - это приятное и забавное развлечение-игра с быстрым движением по кругу. Семантика цикличного движения реализована в нарративных ситуациях приключения главных персонажей повторяются по кругу. На лексическом и грамматическом уровнях семантика движения актуализируется в глаголах движения. На семиотическом уровне семантика движения актуализирована в иллюстрациях, которые визуально напоминают движения по кругу. Такая нарративная структура художественного текста активирует в подсознании ребенка его знания, воспоминания, эмоции, связанные с развлечением-игрой merry-go-round, что стимулирует ребенка проявлять любознательность и заинтересованность в развитии сюжета сказки.

Ключевые слова: модель наррации, сказка, нарративная структура, нарративная ситуация, сюжет.

\section{Introduction}

There exists a magic chemistry of combining elements to create a literary text for children. The formula of putting together plot, structure parts, images, style - is a unique symbiosis which makes a child reader be engaged in the story. Children's literature are literary texts for which the associated writing (awareness of a child audience), publishing (the author's decision to tailor a literary work to conform to an imagined child readership's expectations and tastes), mediatory (librarians', booksellers' and teachers' decisions to orient towards a specific text a child reader rather than an adult reader), critical practices (the critiques of book reviewers and academics should allude to the likehood that children are the intended audience) and readerly practices (conscious or unconscious decision of adult readers to read the book with a child rather than alone) display an awareness of their audience as primarily located within the symbolic childhood of their time and place, that they address a "child audience" (Beauvais 2015: 8-9).

The world of a fairy tale is the world created by adult writers for children. There is a huge gap in the age between the author and his little reader. The author operates with his own memories about the childhood, his own adult experience, his creativity and cultural specifics. The metaphors the author lives by may not correlate with the metaphors children operate with. The main is to "transform", "adopt" the mental schemas of an adult for the audience for children. The conceptual substance of a fairy tale is a blend of the mental construal of an adult and a child. A fairy tale teaches, advertises, educates and motivates. It is not an instruction or a story about real life. It is an imaginary world that has a close connection with the reality. In the fairy tale the magical and the real coexist. A fairy tale is a children's story (a story addressed to the child reader) about magical and imaginary beings and lands, a story in which magic things happen (Macmillan : 249). A fairy tale often tells the story of an individual. It takes into account the entire life of the hero or heroine, but focuses on a single event. Fairy tales mostly have a happy end. Good is rewarded, and evil is punished. The origin of the word fairy demonstrates that it deals with enchantment and miraculous events. The elements of traditional fairy tales are: flatness (fairy tale characters are mere silhouettes, mentioned simply because they are there), abstraction (not many particular, illustrative details are given, the things in fairy tales are described explicitly), intuitive logic (nonsensical sense) and normalized magic (the natural world in a fairy tale is a magical world. The day to day is collapsed with the wondrous. In a traditional fairy tale there is no need for a portal. Enchantment is not astounding. Magic is normal (Bernheimer 2015).

In writing for children an adult as if returns to the child in himself. He experiences the world with vulnerable freshness of a child, with the simplicity, uncertainty and openness to the unconscious 
(Glazer, J., Gurney W. III 1979 : 22). Fairy tales for children tend to be laconic, optimistic, have a clearcut moral schematism, child protagonists. The language and the choice of expressive means as well as stylistic devices have a child oriented tendency (Glazer, J., Gurney W. III 1979 : 19-20].

Narratology as a multidisciplinary science, comprising linguistics and literature, has been in focus of literary studies especially intensified since the twentieth century. Its theory and methodology have been developed in formalism (Propp 1928), structuralism (Genette 1998; Shmid 2003), cognitive narratology (Alber 2016; Korthals Altes 2014; Ogata, Akimoto 2016; Herman 1999), which has developed methods enabling to reveal the interconnection between mental and textual spaces.

Gerard Genette understands narrative as the way in which characters and events of the story are offered to the reader. The narrative level of the narrative text focuses on (a)chronology organizational principles. Narration is the surface level of the narrative text which comes down to the formulation of the story. Narration refers to the concrete and directly visible way in which a story is told, comprising word choice, sentence length and narrating agent of the narrative text (Genette1998 : 64-67 ). The textured network, that is a combination of crucial parts: plot, characters, themes - enables a reader to comprehend a literary text. The contextual factors are cultural specifics, ideological values, the age of the reader. A writer frames (models) what he writes and makes his reader immerse in the text (Toolan 2016).

\section{Methods}

The model of narration is viewed as linguistic and cognitive construal which is inbuilt into the narrative structure of the fairy tale. It integrates compositional plot structure, compositional meaning structure, linguistic and stylistic means of their actualization in the text. It is actualized on the grammatical, semantic and semiotic text levels.

The article aims at reconstruction of the model of narration "Merry-go-round" in Norman Lindsay's fairy tale "The Magic Pudding" and revealing lexical, grammatical and semiotic means of its realization in the text.

The object of the article is the model of narration "Merry-go-round", the subject of the research - lexical, grammatical and semiotic means of its realization

We assume that the model of narration is the way of construing the story-telling, it includes a number of operations, which enable to develop the plot. It is claimed that the models of narration in fairy tales - are play/game models. These models of narration correspond to children plays/games. The model is a logical construction which recreates characteristics and essence of a real object. Games for children tend to be funny and entertaining, they attract their attention and enrich their imagination. In child's mind the thought about any game activates certain scenario and associations. It makes a child get interested and engaged in it.

A game as the phenomenon has been the subject of researches in various humanitarian sciences. A well-known English-Austrian philosopher Ludwig Wittgenstein (2005) developed a conception of games played with and in language. Jaakko Hintikka (Hintikka 1980) basing on Wittegnestein's ideas invented a Game-theoretical semantics.

There is a question about the correlation between the sense of the game and play. Thus, play and game are social activities. Game requires keeping to the fixed rules and measures, but play is a not regulated activity (Chrzanowska-Kluczewska 2004 : 14). Game is a voluntary occupation and it is am aim in itself. Game is accompanied with tension, joy and awareness that it is not real.

Elzbieta Chrzanowska-Kluczewska in her "Language games: pro and against" book describes Caillois taxonomy of games and plays, which unfold into such categories:

- $\quad$ agony games (agon), founded on desire to compete and win, on rivalry (chess of football);

- $\quad$ luck games (alea), based on happy chance and luck (lotteries, roulette, dice); 
- imitation games (mimicry), in which people behave as if they are someone else in different surrounding. These are theatrical performances, balls, dances;

- free play games (ilinx), which are based on bewilderment, intoxication and ecstasy (orgiastic rituals and dance);

- $\quad$ improvisation and imitation games (paidia), which bring pleasure and are rule-free;

- the foundation of organized game (ludus), the tendency to regulate the the gamesome behavior (Chrzanowska-Kluczewska 2004: 15-16).

The methodology of reconstructing narrative play model of narration unfolds into a number of operations aimed at revealing the specifics of its realization on different text levels.

The first stage presupposes the analyses of the semantics of the narrative situations in the text. A narrative situation is viewed as an episode of the text in which events, actions, adventures of the main character are depicted. It corresponds to the compositional plat blocks - exposition, rising action, climax, falling action, resolution.

Second stage deals with the lexical, grammatical (morphological, syntactic), semiotic and stylistic means (expressive means and stylistic devices), enabling to actualize the model of narration. On the lexical and grammatical levels a play model of narration is verbalized via motion verbs.

Third stage aims at revealing the type of narrator and narratator, the kind of communication narrator-narratator as crucial elements of the narrative structure of the text.

\section{Results and Discussion}

The semantics of the name of the model of narration is learned from different thesaurus sources: etymological, synonymous and definitional. It shows up as something that turns round: Merry-goround is a machine with models of animals that children ride on as it turns round (McMillan : 452); 1. A revolving machine with models horse or cars on which people ride for amusement; 2. A continuous cycle of activities. The etymology of the word: merry comes from the old English word myrige, myrge and means pleasant and brief (A short etymological dictionary of modern English : 1996). The definition of the nominative unit Merry-go-round enables us to reveal the most typical features of the word and main characteristics of the game itself. So, it follows that it is something pleasant and funny for children, it moves round, has circular movements. Correspondingly, in the narrative situations in the text exists a certain circulation of the events in the fairy tale "The Magic pudding", stealing and finding the pudding, stealing and finding it again.

In Australian fairy tale "The Magic Pudding" written by Norman Lindsay fairy characters are anthropomorphic Bush-characters: koala bear Bunyip Bluegum, Bill Barnacle, the sailor, and his friend, Sam Sawnoff, the penguin. The plot of the fairy tale: two bears live on a tree, Uncle and his nephew Bunyip. The uncle has long whiskers what makes very uncomfortable to live in a small house in the tree with long whiskers getting everywhere, even in the soup: "The plain truth was that Bunyip and his Uncle lived in a small house in a tree, and there was no room for the whiskers. What was worse, the whiskers were red, and they blew about in the wind, and Uncle Wattleberry would insist on bringing them to the dinner table with him, where they got in soup" (The Magic Pudding)). Because of that Bunyip decides to leave his home and travel. According to Propp's classification such beginning of a fairy tale is a typical one (Propp 1928). While travelling he meets two friends and a Magic Pudding named Albert, a character with anthropomorphic features. Albert talks, sings, grumbles, and wants to be eaten. Three friends call themselves "Noble Society of Pudding Owners" and travel all over the country to have adventures and joy. They are often attacked by sly thieves - a possum and a wombat, who want to steal this Magic pudding Albert.

The plot develops as if it is going round the circle. When the reader tastes his first slice, Bunyip meets his friends and the magic pudding: "...he discovered two people in the very act of having lunch... they had pudding in a basin ). In the second slice the magic pudding named Albert is stolen and then found: "Bunyip Bluegum glanced back in time to see the Wombat in the act of stealing the Puddin' from the hollow log"; "The three friends had Puddin' rescued in no time, and 
shook hands all around, congratulating Bunyip Bluegum on success of his plan (The Magic Pudding, Second slice );

In the next slice events repeat i.e. pudding Albert is stolen by a wombat and a possum: "The worst of it was that the Puddin', being too short to look in, was left outside, and the pudding'thieves grabbed him at once and ran off like winking (The Magic Pudding ,Slice three); and then found by his owners under the hat of the wombat "Hats of in honour of our King", shouted Bill, and off came all the hats. The Puddin'-thieves, of course, were helpless. The Wombat had to take his hat off, or prove himself disloyal, and there was found the Puddin' sitting on his head (The Magic Pudding, Slice three).

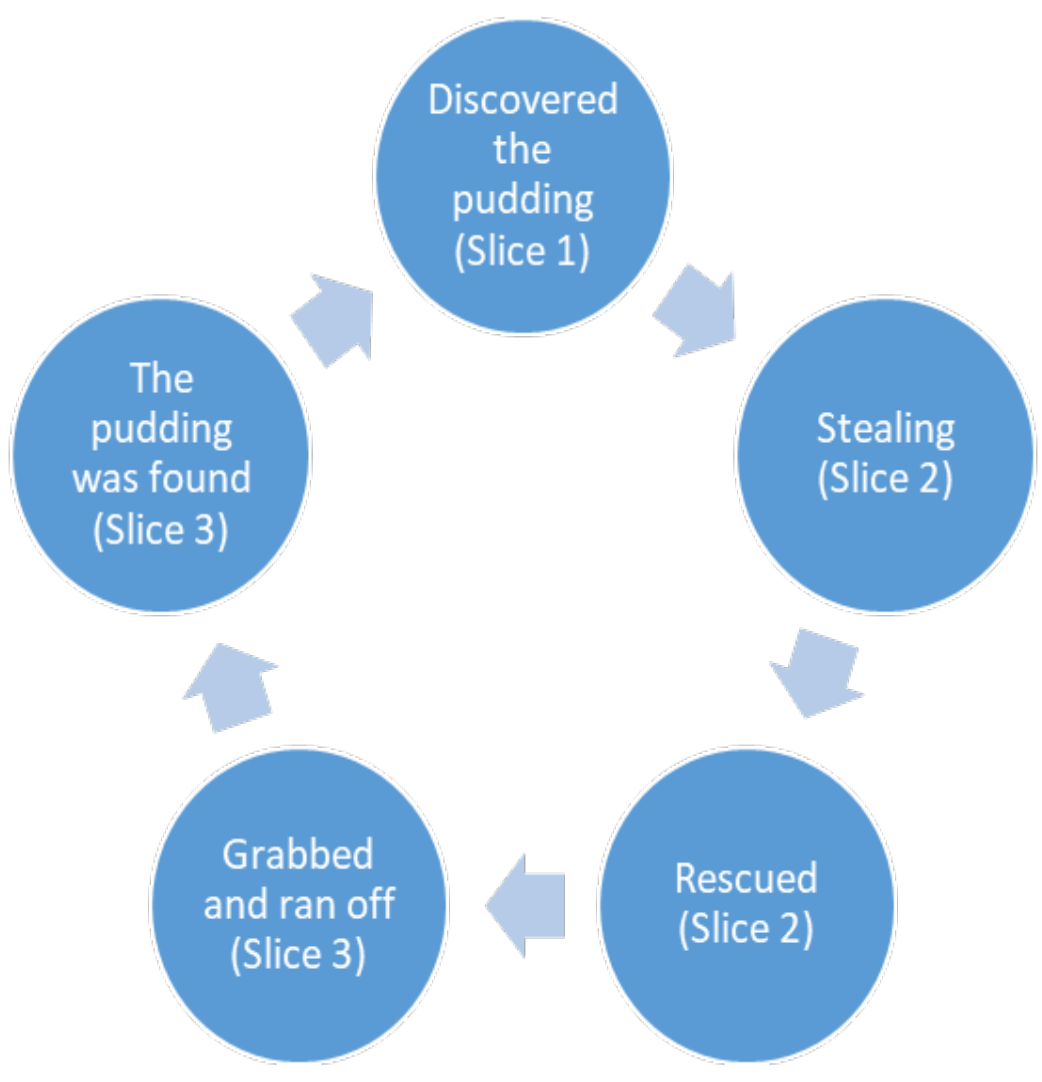

Fig. 1. Schematic representation of the model of narration "Merry-go-round"

The events, depicted in the fairy tale, are funny and repeat one after another reminding a circle. Such composition and plot activate the knowledge of a child about the game Merry-go-round and a child gets involved into the plot and becomes interested in the characters of the fairy tale.

It should be noted that the story is headed not in chapters but it "treats" children with slices. When readers taste the first slice, they meet the main character koala Bunyip and his uncle. The semantics of circular movements is also actualized on the semiotic level. There is an illustration on the first page - two funny koalas are shown full-face. On the other page these koalas are illustrated in profile, on the next - in back, as if they turn round the circle. The readers have the impression that main characters turn round the circle. 

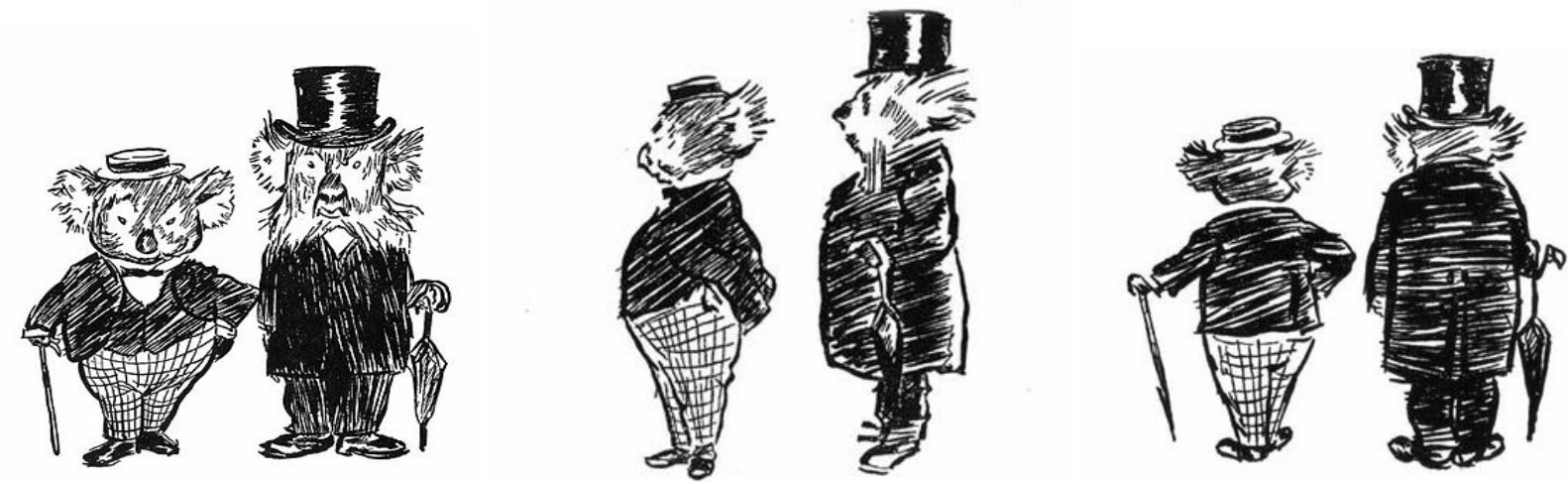

Fig. 2. Semiotic representation of circular movements

On the lexical level the semantics of circular movements is embodied in the meaning of the lexical units with the nmeaning of movement all through the text, on the grammatical level circular movement is reflected via verbs of movement. According to Kubryakova's theory (Kubryakova 1997), about the cognitive nature of the parts of speech, any information, any piece of world, can be realized via three categories. The information, which is realized via the category of action is actualized in speech by means of the motion verbs. Merry-go-round is a dynamic play, it requires movements, fast actions, activity : the Puddin' got out of his basin, remarking-"If you won't eat any more here's giving you a run for the sake of exercise," and he set off so swiftly on a pair of extremely thin legs that Bill had to run like an antelope to catch him up".../... For, as everyone knows, running with the reel is one of the grand joys.../... Bill, distracted with rage, ran after the Possum, then changed his mind and ran after the Wombat, so that, what with running first after one and then after the other.../..."On a terrible quest we run north-west, In a terrible rage we run; With never a rest we run north-west. Till our terrible work is done. Without delay. Away, away, In a terrible rage we run all day (The Magic Pudding).

In the literal sense, the term "narrator" designates the "inner-textual (textually encoded) speech position from which the current narrative discourse originates and from which references to the entities, actions and events that this discourse is about are being made" (Margolin 2009 : 351). In the fairy tale "The Magic pudding" the narrator is a primary global one, the narrator who knows everything about the characters, their story, adventures, thoughts and plans, but at the first and the last page the narrator addresses to the implied child reader: "This is a frontways view of Bunyip Bluegum and his Uncle Wattleberry. At a glance you can see what a fine, round, splendid fellow Bunyip Bluegum is, without me telling you. At a second glance you can see that the Uncle is more square than round...Looked at sideways you can still see what a splendid fellow Bunyip is, though you can only see one of his Uncle's whiskers. Observed from behind, however, you completely lose sight of the whiskers...". It looks like the narrator talks to the child reader. The model corresponds to the play on the playground with the merry-go-round. The narrator, just like an adult in real life, only starts in the merry-go-round into action, and then lets the children play themselves. In the same way the narrator in the fairy tale starts to talk with the implied reader, tells him key notes and then disappears vanishes, becomes a global one.

\section{Conclusions}

The model of narration is a linguistic and cognitive construal, inbuilt into the narrative structure of the text and actualized on different text levels. The model of narration "Merry-go-round" activates in the consciousness of children funny, active game with circular fast movements, and is verbalized in the text on the semantic level by lexical units with the meaning of movement, on the grammatical level via motion verbs. On the narrative level the semantics of circular movements is actualized in narrative situations and the definite type of narrator. The further perspective is seen in reconstruction and description of other models of narration in the Australian and British fairy tales. 


\section{REFERENCES}

A short etymological dictionary of modern English (1996). London / New York : Rouledge. Taylor and Francis group.

Alber, J. (2016). Unnatural narrative. Impossible worlds in fiction and drama. University of Nebraska Press.

Beauvais, C. (2015). The mighty child. Time and power in children's literature. Amsterdam: John Benjamins B.V.

Bernheimer K. Fairy tale is form, form is fairy tale. Available from : http://www.katebernheimer. com/images/Fairy\%20Tale\%20is\%20Form.pdf

Chrzanowska-Kluczewska, E. (2004). Language games: pro and against. TAiWPN Universitas Kraków: Universitas.

Genette, G. (1998). Фигуры [Figures]. Moscow: Izd-vo im. Sabashnikovyh.

Glazer, J., Gurney W. III (1979). Introduction to children's literature. New York: McGraw-Hill.

Herman, D. (1999). Narratologies : New Perspectives on Narrative Analysis. Columbus : Ohio State UP.

Hintikka, Ja. (1980). Logico-epistemologicheskiye issledovaniya [ The Logic of Epistemology and the Epistemology of Logic]. Moscow : Progress.

Korthals Altes, L. (2014). Ethos and narrative interpretation. The negotiation of values in fiction. University of Nebraska Press.

Kubryakove, E. (1997). Chasti rechi s cognitivnoj tochki zrenija [Parts of speech from the cognitive perspective]. Moscow : Institut jazykoznaniya RAN.

Lindsay, N. The Magic pudding (2010). - HarperCollinsPublishers Australia Pty Limited.

Macmillan English Dictionary for Advanced Learners. (2012). London / New York: MacMillan / A.\& C. Black.

Margolin, U. "Narrator" Handbook of narratology (2009). Berlin / New York : Walter de Gruyter, $351-365$

Ogata, T., Akimoto, T. (2016). Computational and cognitive approaches to narratology. The USA: IGI Global.

Propp, V. (1928). Morphologiya Skazki [Morphology of the fairy tale]. Leningrad : Academia.

Schmid, W. (2003). Narratologiya. Moskva: Yazyki slavyanskoj kultury.

Toolan, M. (2016). Making sense of narrative text. Situation, repetition, and picturing in the reading of short stories. New York: Routledge.

Wittgenstein, L. (2005). Izbrannye Trudy [Selected Papers]. Moscow : Territoriya buduschego.

Tsapiv Alla Oleksiyivna - Doctor of Philosophy, Associate Professor, Associate Professor Chair of Theory and Practice of Translation and Applied Linguistics, Kherson State University (27 Universytetska st., Kherson, 73000, Ukraine); e-mail: alyatsapiv@i.ua; ORCID: https://orcid.org/0000-0002-5172-213X

Цапів Алла Олексіївна - кандидат філологічних наук, доцент, доцент кафедри перекладознавства та прикладної лінгвістики, Херсонський державний університет (вул. Університетська, 27, 73000, Україна); e-mail: alyatsapiv@i.ua; ORCID: https://orcid.org/00000002-5172-213X

Цапив Алла Алексеевна - кандидат филологических наук, доцент, доцент кафедры переводоведения и прикладной лингвистики, Херсонский государственный университет (ул. Университетская, 27, 73000, Украина); e-mail: alyatsapiv@i.ua; ORCID: https://orcid.org/00000002-5172-213X 


\title{
GUIDELINES FOR CONTRIBUTORS
}

Article formats: Research Article, Book Review.

All materials should be Times New Roman, 12, font 1; indentation 1,0 cm, margins: left $2 \mathrm{~cm}$., right $-2 \mathrm{~cm}$., top \& bottom $-2.5 \mathrm{~cm}$. Manuscripts may be submitted as email attachments in Microsoft Word 97-2003 (....doc) if they do not contain unusual fonts. If special symbols are used their fonts should be sent separately.

Contributions should be in English. Spelling should be either British or American English consistently throughout. If not written by a native speaker of English it is advisable to have the paper checked by a native speaker.

Papers should be reasonably divided into numbered SECTIONS and, if necessary, subsections.

The title is preceded by the universal decimal classification (UDC) bibliographic code. Example:

\section{UDC code (left on top)}

TITLE (TIMES NEW ROMAN, 12, BOLD, CAPITAL LETTERS, CENTERED)

\author{
First Author Name and Surname (Times New Roman, 14, Bold) \\ (Affiliation: City, Country) \\ Next Author Name and Surname (Times New Roman, 14, Bold) \\ Next Author Name and Surname (Times
}

Abstract: (in three languages (English, Ukrainian, Russian), Times New Roman, 11)

Name \& Surname. Title of the article (bald). An abstract is a brief, comprehensive summary of the contents of the article; it allows readers to survey the contents of an article quickly. The abstract should normally be a single paragraph between 200 and 250 words. A good abstract is accurate, nonevaluative, coherent and readable, clear and concise. It uses verbs rather than their noun equivalents and the active rather than the passive voice; uses the present tense to describe conclusions drawn or results with continuing applicability; uses the past tense to describe specific variables manipulated or outcomes measured. An abstract for a theory-oriented paper should describe: how the theory or model works and/or the principles on which it is based and what phenomena the theory or model accounts for and linkages to empirical results. An abstract for a methodological paper should comprise the general class of methods being discussed; the essential features of the proposed method; and the range of application of the proposed method. Given the small amount of words allowed, each word and sentence included in your abstract needs to be meaningful. In addition, all the information contained in the abstract must be discussed in the main body of the paper.

Keywords: (List five to ten pertinent keywords specific to the article; use singular nouns).

\section{Introduction}

The body of a manuscript opens with an introduction that presents the specific problem under study and describes the research strategy. The structure of the introduction should necessarily comprise the author's aims / tasks / objectives, the subject-matter and the material of the study.

Exploring the importance of the problem the article should state how it is related to previous work in the area. If other aspects of this study have been reported previously, how does this report differ from, and build on, the earlier report?

Describe relevant related literature. This section should review studies to establish the general area, and then move towards studies that more specifically define or are more specifically related to 
the research you are conducting. Your literature review must not be a series of quotations strung together; instead it needs to provide a critical analysis of previous work.

State hypotheses and objectives, their correspondence to research. The statement of the hypothesis should logically follow on from your literature review and you may want to make an explicit link between the variables you are manipulating or measuring in your study and previous research. The present tense is used to state your hypotheses and objectives.

Sections and subsections of the paper. (Times New Roman, 12). Divide your article into clearly defined sections. Any labeled sections / subsection should be numbered (i.e. 2. or 2.1, 2.2 if necessary) and given a brief heading marked in bold (without full stops at the end). Each heading should appear on its own separate line.

A good paragraph should contain at least the following four elements: transition, topic sentence, specific evidence and analysis, and a brief concluding sentence. A transition sentence acts as a transition from one idea to the next. A topic sentence tells the reader what you will be discussing in the paragraph. Specific evidence and analysis support your claims that provide a deeper level of detail than your topic sentence. A concluding sentence tells the reader how and why this information supports the paper's thesis.

\section{Method}

The Method section describes in detail how the study was conducted, including conceptual and operational definitions of the variables used in the study. It also permits experienced investigators to replicate the study.

The method section should be written in paragraph form with as little repetition as possible. This section will often be broken down into subsections such as participants, materials and procedure. The subsections you use will depend on what is useful to help describe and explain your experiment.

In the method section of the paper you should use the past tense since you are describing what you did; for example, e.g. An experiment was performed..., The participants were instructed to ... .

\section{Results}

This section describes but does not explain your results; it provides the reader with a factual account of your findings. You can, however, draw attention to specific trends or data that you think are important. Your aim in your results section is to make your results as comprehensible as possible for your readers/markers.

If you are presenting statistical results, place descriptive statistics first (means and standard deviations) followed by the results of any inferential statistical tests you performed. Indicate any transformations to the data you are reporting; for example, you may report percentage correct scores rather than straight scores. Raw data and lengthy whole transcripts of qualitative data should be put in the appendices, only excerpts (descriptive statistics or illustrative highlights of lengthy qualitative data) should be included in the results section.

In the results section you will need to use both the past tense and the present tense. The past tense is used to describe results and analyses; for example, The knowledge scores were analyzed ..., The results indicated ... .

The present tense is used with results that the reader can see such as means, tables and figures; for example, The means show that ..., The weekly growth rate illustrated in Table 3 illustrates how ... .

Authors should refer in the text to all tables and figures used and explain what the reader should look for when using the table or figure. Focus only on the important point the reader should draw from them, and leave the details for the reader to examine on her own. Each table and figure 
must be intelligible without reference to the text, so be sure to include an explanation of every abbreviation (except the standard statistical symbols and abbreviations).

Give titles to all tables and figures number all tables sequentially as you refer to them in the text (Table 1, Table 2, etc.), likewise for figures (Figure 1, Figure 2, etc.).

\section{Discussion}

If necessary an article may have more sections and subsections.

All examples are italisized. One word or word-combination examples are given within the body of a paragraph.

Sentence or textual examples, preferably numbered through the article, are given in separate paragraphs in italics with indentation $1,25 \mathrm{~cm}$ for the whole paragraph and separated from the previous / following text by one blank line. Example:

(1) "I'm Prendergast," said the newcomer. "Have some port?"

“Thank you, I'd love to." [Waugh 1980:46]

\section{Conclusions}

This section simply states what the researcher thinks the data mean, and, as such, should relate directly back to the problem/question stated in the introduction. By looking at only the Introduction and Conclusions sections, a reader should have a good idea of what the researcher has investigated and discovered even though the specific details of how the work was done would not be known. After moving from general to specific information in the introduction and body paragraphs, your conclusion should restate the main points of your argument.

Conclusions should finish up with an overview of future possible research.

Acknowledgments (not obligatory and not numbered paragraph). Identify grants or other financial support (and the source, if appropriate) for your study. Next, acknowledge colleagues who assisted in conducting the study or critiquing the manuscript. End this paragraph with thanks for personal assistance, such as in manuscript preparation.

In-text citations. If you are directly quoting from a work and the author is not named in a signal phrase, you will need to include the author, year of publication, and the page number for the reference: [Почепцов 1976: 15; Leech 1985: 373].

If the quotation includes the author's last name, it is simply followed by the date of publication in parentheses. For example: (1) According to Jones [2005], "Students often had difficulty using Gerunds and Infinitives, especially when it was their first time" [Jones 2005: 156] If, place the author's last name, the year of publication, and the page number in parentheses after the quotation.

If you cite a work of two to five authors (use ' $\&$ ' within parentheses; use 'and' outside parentheses): (1) Becker and Seligman's [1996] findings contradicted this result. This result was later contradicted [Becker \& Seligman, 1996]. (2) Medvec, Madey, and Gilovich [1995] examined the influence of "what might have been" thoughts on satisfaction among a group of Olympic medalists.

In case of six or more authors, cite only the last name of the first author, followed by "et al." and the year of publication: Barakat et al. [1995] attempted to ...

\section{References (Bald, caps, not numbered)}

A reference list (usually about 30 authors) is a list of all the references cited in the text of your paper, listed in alphabetical order at the end of the paper and not numbered. Each reference in the reference list needs to contain all of the bibliographic information from its source (citation style APA-6). 


\section{For materials in Latin:}

Author, A.A. (Year of Publication). Title of a book. Publisher City, State: Publisher.

Author, A.A. (Year of Publication). Title of an e-book [E-Reader Version]. Retrieved from http://xxxx or doi:xxxx

Author, A.A. (Publication Year). Article title. Journal Title, Volume (Issue), pp.-pp.

Author, A.A. (Publication Year). Article title.Journal Title, Volume (Issue), pp.-pp. doi:XX.XXXXX or Retrieved from journal URL

\section{For materials in Ukrainian or Russian:}

Articles:

Shevchenko, I.S., \& Morozova, Ye.I. (2003). Diskurs kak myslekommunikativnoe obrazovanie [Discourse as a mental and communicative phenomenon]. Visnyk Kharkiv. nats. un-tu im. V.N. Karazina. - V.N. Karazin National Univ. Messenger, 586, 33-38 (in Russian)

E-materials:

Zagurenko, A.A. (2002). Ekonomicheskaya optimizatsia [Economic optimization]. Neftyanoe khozyaistvo - Oil Industry, 11. Available from: http://www.opus

Conference papers:

Zagurenko, A.A. (2002). Osobennosti proektirovaniya [Features of design]. Trudy 6 Mezhdunarodnogo Simpoziuma: Novye tekhnologii - Proceedings from 6th Int. Symposium: New technologies. Kyiv, 267-272 (in Russian).

Books:

Zagurenko, A.A. (2002). Ekonomicheskaya optimizatsia [Economic optimization]. Kyiv: Nauka Publ.

Dissertations:

Zagurenko, A.A. (2002). Ekonomichna optymizatsia. [Economic optimization]. Unpublished candidate dissertation, National Teachers' Training University of Ukraine, Kyiv, Ukraine (in Ukrainian)

Dissertation thesis (abbreviations: dokt./ kand.):

Zagurenko, A.A. (2002). Ekonomichna optymizatsia. [Economic optimization]. Unpublished candidate dissertation synopsis, National Teachers' Training University of Ukraine, Kyiv, Ukraine (in Ukrainian)

For transliteration use http://translit.kh.ua (from Ukrainian) and http://www.translit.ru (from Russian). Use http://apareferencing.ukessays.com/generator/ to created reference list according to APA citation style.

DOIs. A digital object identifier (DOI) is a unique string of letters, numbers, and symbols assigned to a published work to identify content and provide a persistent link to its location on the Internet. The DOI is typically located on the first page of an electronic document near the copyright notice and on the database landing page for the document. When DOIs are available, include them in the reference information. Place the DOI at the end of the reference, and don't add a period at the end of it. Here's an example:

Author, A. A., \& Author, B. B. (Date of publication). Title of article.Title of Journal, volume number, page range. doi:0000000/000000000000 or http://dx.doi.org/10.0000/0000

\section{DATA SOURCES (Bald, caps, not numbered)}

All textual examples cited in the article should have full bibliographic information about their sources listed in alphabetical order and not numbered (citation style APA-6).

Author's research profile. All articles are followed by the author's research profile in English, Ukrainian, Russian, containing information about his/her name \& surname, title, affiliation and work address, e-mail, ORCID. Example:

Vakhovska Olha Volodymyrivna - PhD in Linguistics, Associate Professor, Department of English Linguistics and Philosophy of Language named after Prof. Dr. phil. A.N. Morokhovskiy, Faculty of Germanic Linguistics, Kyiv National Linguistic University (Velyka Vasylkivska Street 73, Kiev, Ukraine, 03680); e-mail: vakhovskayaolga@ gmail.com; ORCID: 0000-0002-7720-0970 


\section{РЕКОМЕНДАЦИИ АВТОРАМ ЖУРНАЛА «ККД» по оформлению статей научных журналов \\ для включения в зарубежные индексы цитирования}

Материалы принимаются в объеме не менее 0.5 авторского листа (10 стр.) предпочтительно на английском языке в текстовом редакторе Microsoft Word (.doc), шрифт Times New Roman, размер шрифта 12, интервал 1. Текст форматируется по ширине. Отступ для абзаца 1,0 см, поля: слева и справа -2 см., вверху и внизу $-2,5$ см. В левом углу указывается УДК. По центру заглавными буквами жирным шрифтом пишется название статьи. На следующей строке по центру указываются инициалы и фамилии авторов, в скобках - город, страна. Например:

УДК ........

\section{ВТОРИЧНАЯ РЕПРЕЗЕНТАЦИЯ ЗНАНИЙ В КОГНИЦИИ И ДИСКУРСЕ}

\section{А.Н. Петренко (Киев, Украина)}

Далее 11 кеглем приводятся аннотации на английском, украинском и русском языках Авторам рекомендуется структура аннотации, повторяющая структуру статьи, однако, предмет, тема и цель работы указываются в том случае, если они не ясны из заглавия статьи. Текст резюме должен быть максимально информативен, не повторять формулировки в названии статьи, не содержать вводных предложений, типа «В статье автор рассматривает...». Результаты работы представляются максимально точно и информативно. При этом предпочтение отдается новым результатам, и данным долгосрочного значения, важным открытиям и выводам, которые опровергают или дополняют существующие теории. Разрозненные положения в тексте должны логично вытекать одно из другого. Допускаются только общеизвестные аббревиатуры, либо дается расшифровка авторских аббревиатур при первом их употреблении. Объем аннотации - минимум 200 - 250 слов. В конце аннотации с новой строки после фразы жирным шрифтом с абзацным отступом «Ключевые слова» в алфавитном порядке перечисляются основные понятия из статьи (в единственном числе). Не рекомендуется приводить термины, не употребленные в аннотации.

Аннотация является, практически, единственным источником, на основании которого иностранный читатель может составить представление о сути и ценности статьи. Поэтому главными требованиями к ней являются: информативность (отсутствие общих и вводных фраз), содержательность (отражение основного содержания статьи и результатов исследований), структурированность (следование логике аргументации статьи), аутентичность (качественный английский язык), компактность. В тексте авторского резюме следует употреблять синтаксические конструкции, свойственные языку научных и технических документов, избегать сложных грамматических конструкций. Рекомендуется включение в аннотацию следующих структурных компонентов: Purpose (цели и задачи исследования), Results (результаты и выводы) и Discussion (практическое значение и перспективы). Текст должен быть связным с использованием слов «следовательно», «более того», «например», «в результате» и т.д. («consequently», «moreover», «for example», «the benefits of this study», «as a result» etc.), либо разрозненные излагаемые положения должны логично вытекать один из другого. Необходимо использовать активный, а не пассивный залог, т.е. «The study tested», но не «It was tested in this study» (частая ошибка российских аннотаций).

В конце после фразы жирным шрифтом с абзацным отступом «Кеy words» в алфавитном порядке перечисляются основные термины, употребляемые в статье. Желательно употребление терминологии, общепринятой в мировой науке. См. рекомендации зарубежных издательств (Emerald Publishing, http://www.emeraldinsight.com/authors/guides/write/abstracts.htm).

Структура статьи после аннотаций различается для эмпирической и теоретической статей. 
Эмпирическая статья (Empirical/Case Study)

Статья представляет результаты экспериментального исследования, иллюстрации выявленной проблемы; анализ способов решения проблемы; обоснование необходимости исследований в какой-либо сфере. Структура эмпирической статьи, как правило, включает разделы:

Аннотация эмпирического исследования должна отражать: проблему исследования; его гипотезу; полное описание выборки; основные особенности методологии и метода исследования; краткое описание полученных результатов, их надежности и сферы применения.

1. Введение (Introduction): постановка и обоснование проблемы, анализ последних исследований и публикаций; выявление нерешенных проблем и предложение пути их решения; актуальность исследования; определение цели (теоретической и практической) и гипотезы исследования; описание хода изложения материала в статье.

2. Методология исследования (Methods) - описание степени разработанности проблемы в научных публикациях, методологических основ и методов, процедуры проведения исследования, описание выборки, возможные погрешности результатов. Этот раздел призван дать четкое представление об объективности полученных результатов.

3. Результаты исследования (Results) - описание результатов (с иллюстрациями, таблицами, которые нумеруются и снабжаются названием) и их анализ. Этот раздел статьи можно дополнительно структурировать на подразделы. Результаты проведенного исследования оформляются в виде списков.

4. Обсуждение и дискуссия (Discussion) - интерпретация полученных результатов; их сравнение с аналогичными результатами других исследований по тематике статьи; предложения по применению собственных выводов; предложение дальнейших направлений исследований. Этот раздел всегда насыщен ссылками. Задача автора - подготовить в дискуссионной части статьи обоснованную поддержку всем выводам, которые он планирует сделать по результатам исследования.

5. Выводы (Conclusions) - важнейшая часть статьи, краткое изложение тезисов, которые автор предлагает на профессиональное обсуждение по результатам проведенного исследования, имея целью показать важность своего исследования и его перспективы.

Благодарность (факультативный раздел) выражается ученым, коллегам, друзьям, помогавшим в работе, а также спонсорам, грантодателям и т.д.

\section{Теоретическая статья (Theoretical article)}

В статье на основе существующей литературы разрабатываются имеющиеся / выдвигаются новые теоретические положення. Она содержит анализ развития теории, уточнение теоретических конструктов, представление новой теории, сравнение нескольких теорий, демонстрация преимуществ одной теории по сравнению с другой. Структура такой статьи зависит от ее содержания. Эмпирические данные вводятся, если они важны для решения теоретической проблемы.

Структура теоретической статьи, как правило, включает разделы:

Аннотация для теоретической статьи должна описывать: как теория или модель работает; принципы, на которых она основана; основные особенности представленной теории / метода, какие явления она учитывает и объясняет; ее надежность и связи с эмпирическими результатами.

Введение (Introduction). Постановка проблемы; актуальность исследования; краткий анализ последних исследований и публикаций для выделения нерешенных ранее частей общей проблемы, которым посвящается данная статья; определение цели, задач (как правило, нескольких) (Aims / tasks / objectives).

В основной части (под соответствующим теме названием) статья может иметь 
дальнейшие подразделы (Sections and subsections). Как правило, она начинается с детального изложения и всестороннего анализа известных результатов и теорий. Далее приводится нужное количество подразделов, отражающее ответы на каждый поставленный автором вопрос и дискуссию с обоснованием полученных результатов. При необходимости свои доводы автор подкрепляет нумерованными примерами, таблицами, рисунками.

Выводы (Conclusions) суммируют полученные результаты и дают ответы на все поставленные ранее вопросы (в соответствии с целью и заданиями статьи). Намечаются конкретные перспективы дальнейших исследований в этом направлении.

Благодарность (факультативный раздел) выражается ученым, коллегам, друзьям, помогавшим в работе, а также спонсорам, грантодателям и т.д.

\section{Перечень обязательных элементов любой статьи включает:}

Введение (Introduction), актуальность, цель, задачи (Aims / tasks / objectives) исследования, его объект, предмет, материал; подзаголовки статьи (Sections and subsections), выводы (Conclusions) и перспективы исследований в этом направлении.

Все структурные элементы необходимо выделять полужирным шрифтом.

Примеры и их перевод выделяются курсивом, нужное в них подчеркивается. Примеры слова и словосочетания приводятся внутри соответствующего абзаца. Примеры предложения и текстовые фрагменты, желательно нумерованные, выносятся в отдельный абзац, располагаются на расстоянии абзацно отступа слева и отделяются от предшествующего и последующего текста пустой строкой.

Разделы и подразделы нумеруются, важнейшие понятия даются жирным шрифтом; авторы могут использовать подчеркивание. Растяжка шрифта, подстрочные сноски в электронных изданиях не допускаются. При необходимости возможны примечания после текста статьи перед списком литературы.

Рекомендуемое среднее число ссылок в статье составляет 10-30 публикаций. Внутристатейные ссылки на литературу оформляются в квадратных скобках по образцу [Арутюнова 1976: 15; Leech 1985: 373].

В конце статьи приводится список литературы.

ЛИТЕРАТУРА (заглавными буквами полужирным шрифтом без двоеточия в конце) дается как ненумерований список в алфавитном порядке, где по требованиям ДАК Украины сначала размещаются публикации на кириллице, затем - на латинице. Тире и дефис различаются.

Пример:

1. Демьянков В.З. Когнитивная лингвистика как разновидность нтерпретирующего подхода / В.3. Демъянков // Вопросы языкознания. - 1994. - № 4. - С. 17-33.

2. Смущинська I.В. Модальність французького художнього тексту: типи та засоби вираження : дис. ... доктора філол. наук : 10.02.05 / Смущинська Ірина Вікторівна. - К., 2003. $-478 \mathrm{c}$.

3. Карпова Е.В. Стратегии вежливости в современном английском языке (на материале малоформатных текстов) : автореф. дис. на соискание учен. степ. канд. филол. наук : спец. 10.02.04 «Германские языки» / Е.В. Карпова. - СПб, 2002. - 17 с.

4. Попова 3.Д. Когнитивная лингвистика / З.Д. Попова. - М. : АСТ: «Восток - Запад», 2007. - 314 c.

Для статьи, написанной по-русски, список литературы приводится дважды: сначала ЛИТЕРАТУРА, затем ее дублирование в латинице REFERENCES. Для статьи, написанной по-английски или на другом европейском языке, дается только REFERENCES.

После слова REFERENCES (заглавными буквами полужирным шрифтом без двоеточия в конце) приводится ненумерованный алфавитный список всех источников по 
образцу APA style $6^{\text {th }}$ (порядок авторов в двух списках может быть разным в соответствии с конкретным алфавитом).

Оформление REFERENCES по стандарту APA style (6 ${ }^{\mathrm{e}}$ изд.):

Названия журналов, издательств транслитерируются латиницей и не переводятся.

Для изданий на кирилице:

Статья:

Shevchenko, I.S., \& Morozova, Ye.I. (2003). Diskurs kak myslekommunikativnoe obrazovanie [Discourse as a mental and communicative phenomenon]. Visnyk Kharkiv. nats. un-tu im. V.N. Karazina. - V.N. Karazin National Univ. Messenger, 586, 33-38 (in Russian)

Электронный источник:

Zagurenko, A.A. (2002). Ekonomicheskaya optimizatsia [Economic optimization]. Neftyanoe khozyaistvo - Oil Industry, 11. Available from: http://www.opus

Материалы конференции:

Zagurenko, A.A. (2002). Osobennosti proektirovaniya [Features of design]. Trudy 6 Mezhdunarodnogo Simpoziuma: Novye tekhnologii - Proceedings from 6th Int. Symposium: New technologies. Kyiv, 267-272 (in Russian).

Книга:

Zagurenko, A.A. (2002). Ekonomicheskaya optimizatsia [Economic optimization]. Kyiv: Nauka Publ.

Диссертация:

Zagurenko, A.A. (2002). Ekonomichna optymizatsia. [Economic optimization]. Unpublished candidate dissertation, National Teachers' Training University of Ukraine, Kyiv, Ukraine (in Ukrainian)

Автореферат диссертации (сокращения: dokt./ kand.):

Zagurenko, A.A. (2002). Ekonomichna optymizatsia. [Economic optimization]. Unpublished candidate dissertation synopsis, National Teachers' Training University of Ukraine, Kyiv, Ukraine. (in Ukrainian)

Для изданий на иностранном европейском языке

Книга одного автора:

Lakoff, G. (1980). Metaphors We Live By. Chicago: Chicago University Press.

Книга БЕЗ автора, под. редакцией:

Lakoff, G. (Ed.). (1980). Title of the book. Chicago: Chicago University Pres.

Книга нескольких авторов:

Jung, C., \& Franz, M. (1964). Man and his symbols. New York: Doubleday Publ.

Статья:

Author, A. Author, B.B., \& Author, C.C. (2005). Titile of the article. Title of the journal, 10 (2), 49-53. 
Глава в книге:

Shuman, A. (1992). Entitlement and authoritative discourse. In: J.H. Hill, \& J.T. Irvine (Eds.). Responsibility and evidence in oral Discourse (pp. 135-160). Cambridge and New York: Cambridge University Press.

Обязательно указывать идентификаторы DOI для тех источников, где они есть, например: Brownlie, D. (2007). Toward effective poster presentations. European Journal of Marketing, 41, 1245-1283. doi:10.1108/03090560710821161

Транслитерацию рекомендуется делать автоматически на сайтах http://translit.kh.ua/ (для украинского языка) и http://www.translit.ru (для русского). Оформление в соответствии с АРА-6 citation style рекомендуется делать на сайте http://apareferencing.ukessays.com/generator/

В конце статьи после библиографии дается информация об авторе на английском, украинском и русском языках: ФИО (полностью), степень и звание автора, место работы (полное название так, как оно дано на сайте, и почтовый адрес организации), город, страна, электронный адрес для корреспонденции, ORCID. 


\section{SCHOLARLY JOURNAL}

COGNITION, COMUNICATION, DISCOURSE

International on-line scholarly journal. 2018, № 16

Series "Philology"

Englisn and multilanguages

$\begin{array}{ll}\text { Computer version } & \text { L.P. Z'abchenko } \\ \text { Journal web-site } & \text { V.O. Shevchenko }\end{array}$




\section{НАУКОВЕ ВИДАННЯ}

КОГНІЦІЯ, КОМУНІКАЦІЯ, ДИСКУРС

Міжнародний електронний збірник наукових праць. 2018, № 16

Напрямок «Філологія»

Англійською та іншими мовами

Комп'ютерне верстання

Комп’ютерна підтримка сайту
Л.П. Зябченко

В.О. Шевченко

61022, м. Харків, майдан Свободи, 4

Харківський національний університет імені В. Н. Каразіна 